\title{
Geology of the Cenozoic Indus Basin sedimentary rocks: Paleoenvironmental interpretation of sedimentation from the western Himalaya during the early phases
of India-Eurasia collision
}

\author{
Alexandra L. Henderson, ${ }^{1}$ Yani Najman, ${ }^{1}$ Randall Parrish, ${ }^{2}$ Marcelle BouDagher-Fadel, ${ }^{3}$
} Dan Barford, ${ }^{4}$ Eduardo Garzanti, ${ }^{5}$ and Sergio Andò ${ }^{5}$

Received 18 December 2009; revised 9 August 2010; accepted 20 August 2010; published 24 December 2010.

[1] This study reassesses the stratigraphy, sedimentology, and provenance of the Indus Basin sedimentary rocks, deposited within the Indus Tsangpo Suture Zone (ITSZ) during the early phases of India-Eurasia collision. Using field observations, biostratigraphy, and petrographic and isotopic analyses we create a paleodepositional reconstruction within the paleotectonic setting of the early phases of India-Eurasia collision. We then re-examine existing constraints to the timing of IndiaEurasia collision previously interpreted from the earliest occurrence of mixed Indian- and Eurasian-derived detritus in the succession. From mid-Cretaceous to early Paleocene times the Jurutze and Sumda Formations were deposited within an arc-bounded marine basin between the Dras and Kohistan-Ladakh Island arcs. The $<51 \mathrm{Ma}$ aged deltaic Chogdo Formation then filled the basin until deposition of the 50.8-49.4 Ma aged Nummulitic Limestone during a marine incursion, before continental facies developed in an evolving intermountain basin with the deposition of the Paleogene Indus Group. Within these systems, sediment was sourced from the Eurasian margin to the north and was transported southward into the suture zone. In this section, we see no unequivocal evidence of Indian Plate input to the sedimentary succession (and thus no evidence of mixed Indian-Eurasian-derived detritus indicative of IndiaAsia collision) until the upper stratigraphic horizons of the Indus Group, when facies are representative of an axial, northwesterly flowing river system. We suggest that the paleo-Indus River was initiated within the ITSZ during late Oligocene-early Miocene times. Sedimentation of the Indus Group continued until

\footnotetext{
${ }^{1}$ Lancaster Environment Centre, University of Lancaster, Lancaster, UK ${ }^{2}$ NERC Isotope Geosciences Laboratory, Kingsley Dunham Centre, Keyworth, UK.

${ }^{3}$ Department of Earth Sciences, University College London, London, UK.

${ }^{4}$ SUERC, Glasgow, UK.

${ }^{5}$ Dipartimento di Scienze Geologiche e Geotecnologie, Universita Milano-Bicocca, Milan, Italy.

Copyright 2010 by the American Geophysical Union. 0278-7407/10/2009TC002651
}

the late Miocene. Citation: Henderson, A. L., Y. Najman, R. Parrish, M. BouDagher-Fadel, D. Barford, E. Garzanti, and S. Andò (2010), Geology of the Cenozoic Indus Basin sedimentary rocks: Paleoenvironmental interpretation of sedimentation from the western Himalaya during the early phases of India-Eurasia collision, Tectonics, 29, TC6015, doi:10.1029/2009TC002651.

\section{Introduction}

[2] The Cenozoic Indus Basin sedimentary rocks (IBSR), also referred to as the Indus Molasse, Indus Formation, or Kargil Formation [e.g., Clift et al., 2001a; Frank et al., 1977; Gansser, 1977; Searle et al., 1990; Shah et al., 1976; Thakur, 1981; Wu et al., 2007] are a succession of clastic and carbonate sedimentary rocks deposited within the Indus-Tsangpo Suture zone (ITSZ) in what previous studies considered to be an evolving forearc to intermontane basin setting during the initial and early phases of India-Eurasia continental collision.

[3] The Paleogene depositional age for the well-preserved Indus Basin sedimentation [Green et al., 2008; Sinclair and Jaffey, 2001; van Haver, 1984], conveniently spans the commonly quoted age for initial India-Eurasian collision; 50-55 Ma [e.g., Clift et al., 2002a; de Sigoyer et al., 2000; Leech et al., 2005; Powell and Conaghan, 1973; Tonarini et al., 1993]. It is for this reason that the Indus Basin sedimentary succession holds a record of early Himalayan erosion, useful for constraining the timing of India-Eurasia collision (as evidenced by earliest record of mixed Indian and Asian detritus, first evidence of Asian detritus deposited on the Indian plate, and timing of cessation of marine facies), and reveals insight into the pattern of exhumation of individual geological terranes exposed throughout the Paleogene. Furthermore, through facies examination and interpretation, it is also possible to obtain an insight into the paleodepositional environments which dominated the Indus Basin during early Himalayan evolution. However, the combination of intense postdepositional deformation, limited biostratigraphy, rapid facies changes, and limited lateral extent of many Indus Basin sedimentary formations, has presented great challenges for geologists and has hampered the extent to which stratigraphic work can be used as a precise way of constraining the timing of India-Eurasia collision [e.g., Clift et al., 2002a; Searle et al., 1990] and early Himalayan evolution [Clift et al., 2001a; Clift et al., 2002a; Garzanti and van Haver, 1988; Searle et al., 1990; Sinclair and Jaffey, 2001]. 
[4] In order to generate a more detailed understanding of early Himalayan evolution from this sedimentary archive, the prime objective of this paper is to create a better defined, detailed stratigraphy obtained from a "type section" of the geology exposed along the Zanskar River Gorge in northern India. This is achieved through a combination of detailed geological mapping and geochemical characteristics. Each individual Indus Basin formation is characterized and distinguished based on facies, petrography, and isotopic characteristics. We then use our findings to discuss (1) the paleoenvironmental conditions, (2) the origin of detrital sediments, and (3) the pattern of sediment transport which dominated the early phases of India-Eurasian collision. From this we are able to produce a paleotectonic reconstruction for precollisional and early collisional stages of Himalayan evolution, focusing on the potential ways by which the IBSR might contribute to our understanding of the timing of India-Eurasia collision and show evidence for initiation of the paleo-Indus River.

\section{Geology of the Himalaya}

[5] In order to generate an understanding of paleogeographic settings during Indus Basin sedimentation, and the provenance of these rocks, it is necessary to catalog the characteristics of the main Himalayan geological units as displayed in Figure 1. These units can be divided into two groups; those comprising the original Eurasian continental block (Lhasa-Karakoram block and Transhimalayan arc) and those representing the Indian Plate (Tibetan Sedimentary Series, High Himalaya, and Lesser Himalaya), separated by the Indus Tsangpo Suture Zone (ITSZ).

[6] At the most northerly extent of the Himalaya lies the Lhasa-Karakoram block; consisting of an assemblage of igneous, metamorphic and sedimentary rock units, representing the southern margin of the original Eurasian continent [e.g., Gaetani, 1997; Le Fort et al., 1994; Rolland et al., 2002a]. The Karakoram and Lhasa Terranes are considered to have existed previously as a single tectonic unit, now separated by the Karakoram Fault [e.g., Searle et al., 1988]. To the south of the Karakoram-Lhasa block lies the Kohistan Ladakh Island Arc (KLIA), considered to have collided with the southern margin of Eurasia during mid to late Cretaceous times [e.g., Clift et al., 2000; Maheo et al., 2006; Robertson and Degnan, 1994; Rolland et al., 2000, 2002b; Schärer et al., 1984b; Searle et al., 1988; Sutre, 1990; Treloar et al., 1996], creating the Shyok Suture Zone (SSZ) [Robertson and Collins, 2002].

[7] Continuing after arc-continent collision, further granitic intrusion and volcanism occurred within the now combined KLIA-Eurasian margin, along the Transhimalayan Batholith (TH); an Andean style granodioritic continental arc, formed during the northward subduction of the Tethyan oceanic crust underneath the Eurasian plate [e.g., Allégre et al., 1984; Garzanti et al., 1987; Honegger et al., 1982]. The lateral extensiveness of the Transhimalaya spans the length of the Himalayan chain and is characterized by much geochemical variation. Mid-Cretaceous arc volcanism and associated plutonic intrusion began at ca. 90-110 Ma [Schärer et al., 1984a; Treloar et al., 1989a] with magmatic activity continuing into postcollisional times [e.g., Heuberger et al., 2007].
[8] Located to the south of the Transhimalaya is the Indus-Tsangpo Suture Zone, currently considered to contain both precollisional Cretaceous-Paleocene forearc basin and postcollisional Cenozoic intermontane basin sedimentary rocks [Garzanti and van Haver, 1988; Searle et al., 1990; van Haver, 1984], all of which were subsequently subjected to postcontinental collision polyphase fold-thrust deformation with associated anchizonal metamorphism [Garzanti and van Haver, 1988; Searle et al., 1988; Treloar et al., 1989b]. To the south of the Indus-Tsangpo Suture Zone exists the Neoproterozoic-Paleocene Tethyan Sedimentary Series (TSS), representing precollisional sedimentary deposition on the northern passive margin of India from Permian times onward [Gaetani and Garzanti, 1991]. A large normal fault system of the South Tibet Detachment Zone (STDZ) separates the Tethyan Sedimentary Series from the Higher Himalaya $(\mathrm{HH})$ to the south. The Higher Himalayan terrane consists of Indian Plate Proterozoic - early Paleozoic metasedimentary rocks and associated magmatic rocks of similar and younger (Cambro-Ordovician and Neogene) age [DeCelles et al., 2000; Gehrels et al., 2003; Myrow et al., 2003; Parrish and Hodges, 1996; Richards et al., 2005]. Barrovian-style prograde metamorphism affected the Higher Himalaya between 37 and $25 \mathrm{Ma}$ [Searle et al., 1992; Simpson et al., 2000; Vance and Harris, 1999; Vannay and Hodges, 1996; Walker et al., 1999] with subsequent decompressive melting and production of leucogranites between 25 and 12 Ma [Hodges et al., 1996; Le Fort, 1996; Prince et al., 1999; Searle et al., 1997b; Simpson et al., 2000; Vance and Harris, 1999]. Separated from the Higher Himalaya by the Main Central Thrust (MCT), the Lesser Himalaya (LH) is composed predominantly of low grade to unmetamorphosed Indian crustal rocks dominantly of Precambrian to Paleozoic age [Frank et al., 1995; Oliver et al., 1995; Tewari, 1993; Valdiya, 1980; Valdiya and Bhatia, 1980]. At the southern frontier of the Himalaya are the foreland basin sedimentary rocks of the Subhimalaya; separated from the Lesser Himalaya by the Main Boundary Thrust (MBT), and emplaced over the modern-day foreland basin by the blind thrust system of the Main Frontal Thrust (MFT).

\section{Geology of the Indus Basin Sedimentary Rocks}

[9] The IBSR are located within the Ladakh region of northern India and can be traced along a northwestsoutheast trending strike for $\sim 2000 \mathrm{~km}$. A summary of current published Indus Basin stratigraphies from different study areas alongside their associated paleodepositional environments, including the work of this study, are presented in Figure 2.

[10] The oldest units comprise a late Albian-early Eocene sequence of dominantly marine, plus a lesser proportion of continentally deposited, sediments considered to represent deposition within the forearc basin of the Transhimalayan arc prior to continental collision [Clift et al., 2002a; Garzanti and van Haver, 1988; Searle et al., 1990; Sinclair and Jaffey, 2001; Steck et al., 1993]. This older sequence has been collectively referred to as the Tar Group [Searle et al., 1990; Sinclair and Jaffey, 2001], Serie verte de Tar 


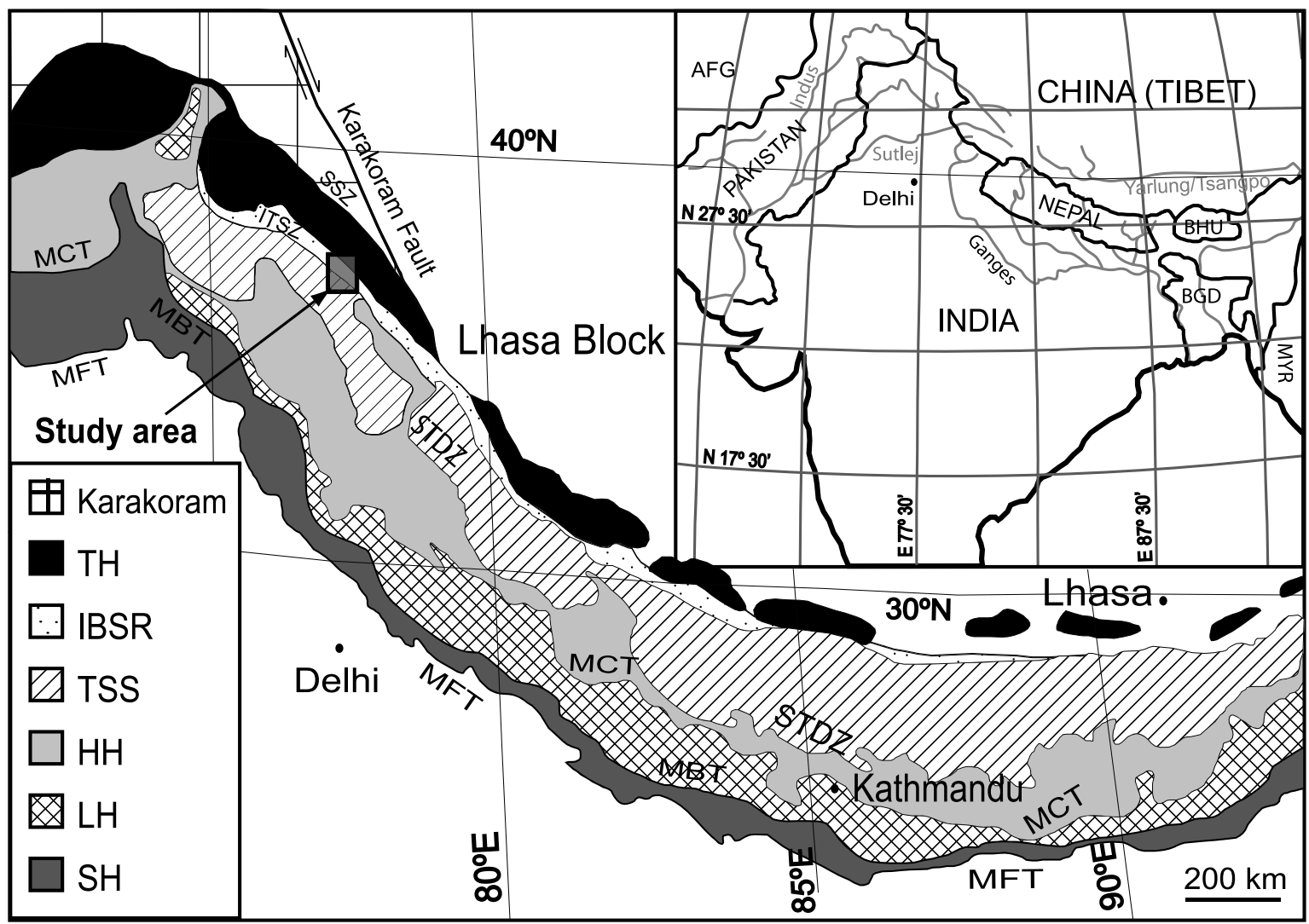

Figure 1. Simplified geological map of the Himalaya, adapted from Foster and Carter [2007] and Dèzes [1999]. TH, Transhimalaya; IBSR, Indus Basin sedimentary rocks; TSS, Tibetan Sedimentary Series; HH, High Himalaya; LH, Lesser Himalaya; SH, Subhimalaya; MFT, Main Frontal Thrust; MBT, Main Boundary Thrust; MCT, Main Central Thrust; STDZ, South Tibet Detachment Zone; ITSZ, Indus Tsangpo Suture Zone; SSZ, Shyok Suture Zone; AFG, Afghanistan; BHU, Bhutan; BGD, Bangladesh; MYR, Myanmar. The location of the study area is indicated by the gray box. Inset country map displays the major river drainage operating throughout the Himalaya adapted from Sinclair and Jaffey [2001], depicting the location of the Indus River, as discussed in section 9.

[van Haver, 1984], or Indus Flysch [Fuchs, 1979, 1981; Gansser, 1977]. Conformably above the Tar Group, and separated by the Nummulitic Limestone exists a post-early Eocene sequence of continental sedimentary rocks representing gradual transition from forearc to intermontane basin deposition during the initial stages of continental collision [Baud et al., 1982; Garzanti and van Haver, 1988; Sinclair and Jaffey, 2001; van Haver, 1984]. These continental sediments were first recognized by Tewari [1964] and named the Indus Molasse or Indus Group [Searle et al., 1990; Sinclair and Jaffey, 2001].

[11] To the north, the upper stratigraphic levels of the Indus Group unconformably rest upon granodiorites and associated lavas of the Transhimalaya and Kohistan-Ladakh Island Arc [Gansser, 1977; Garzanti and van Haver, 1988; Searle et al., 1997a; Sharma and Gupta, 1983; van Haver, 1984]. A number of different stratigraphic relationships have been previously proposed to exist at the base of the IBSR. Searle et al. [1990] considered the older IBSR, located to the south, to disconformably overlie Cretaceous volcaniclastic forearc basin sediments of the Nindam Formation, whereas Clift et al. [2002a, 2000, 2001a] considered the IBSR to overlie Aptian-Albian Cretaceous platform limestone of the Khalsi Flysch, Mesozoic Indian passive margin deepwater sediments of the Lamayuru Group, and ophiolitic mélange. These contradictory observations regarding the IBSR relationship with underlying units most likely result from misidentification of strata, and have been clarified in work by A. L. Henderson et al. (Constraints to the timing of India-Eurasia collision: A re-evaluation of evidence from the Indus Basin sedimentary rocks, submitted to Earth-Science Reviews, 2010).

[12] The IBSR have been subjected to post depositional northeast-southwest directed compressional deformation resulting in the growth of large kilometer-scale folds with northwest-southeast trending fold axes. Our mapping (Figure 3) agrees with Searle et al. [1990] in the recognition of a later phase of northwest-southeast directed compressional deformation. This has resulted in the refolding of the initial folds; developing overturned or recumbent saddle and 


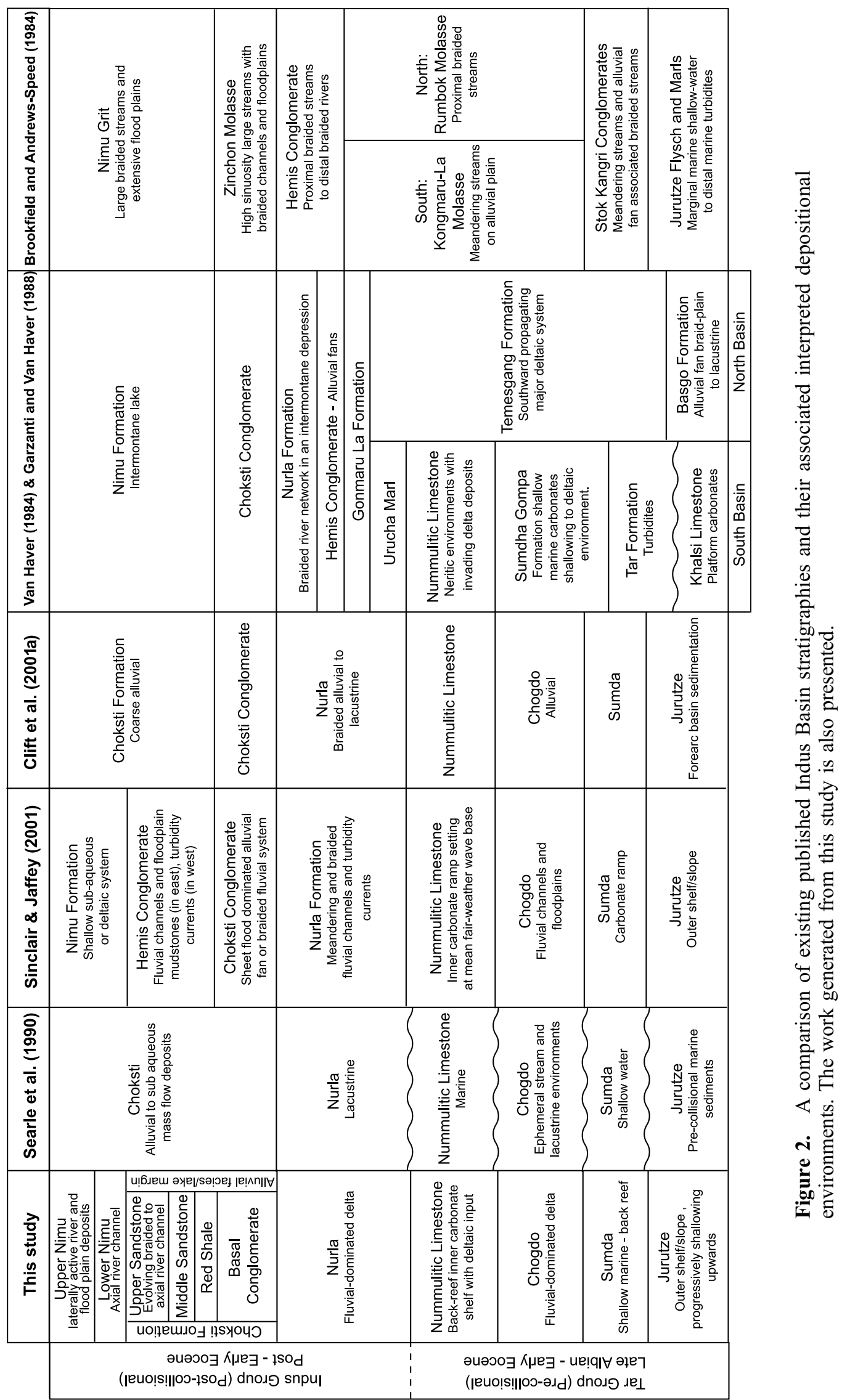




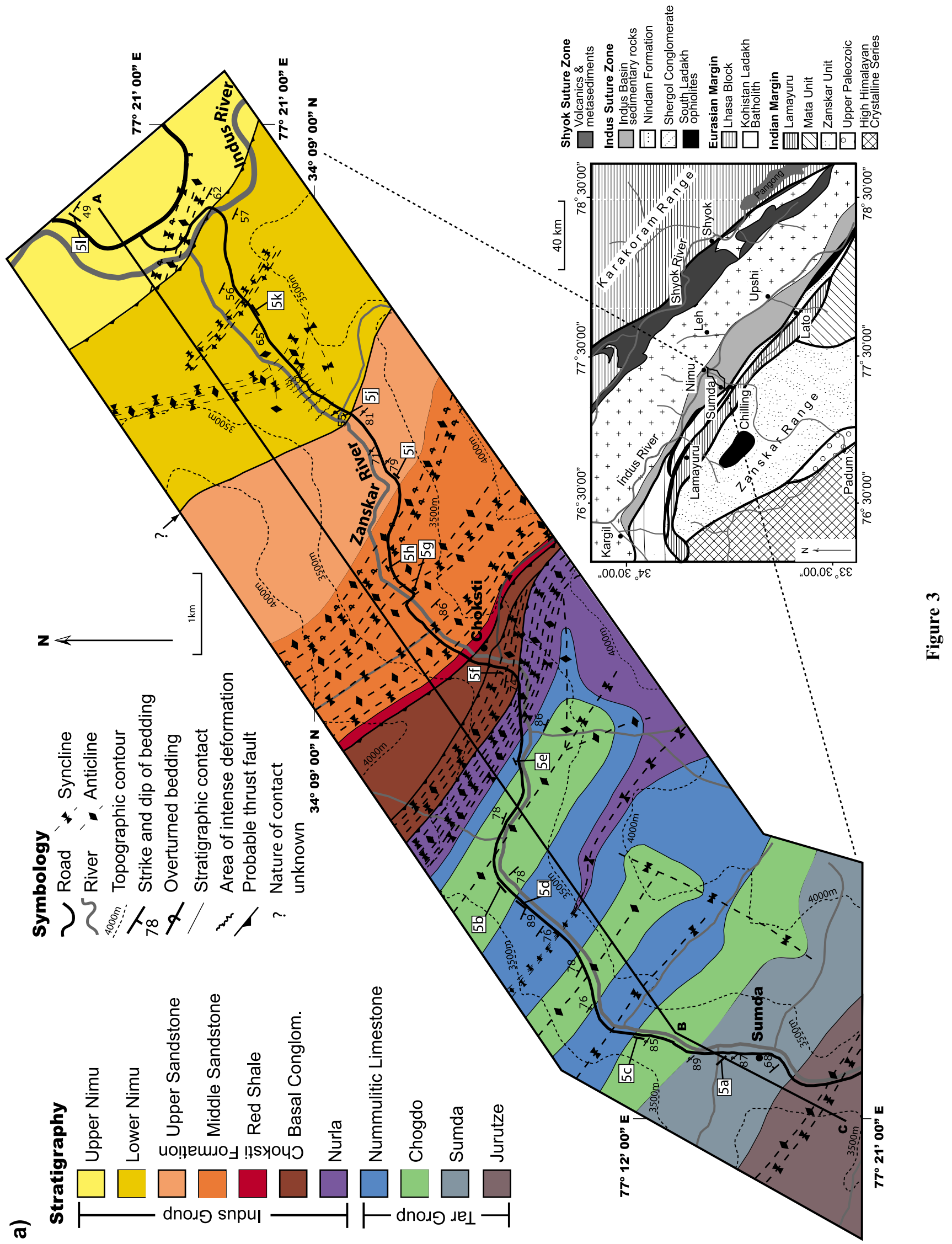


canoe fold morphologies. Small-scale extensional faulting is also observed. We suggest that the intensity of deformation affecting the IBSR combined with a paucity of biostratigraphic data and a lack of stratigraphic younging evidence present in lower stratigraphic levels, has hampered previous attempts at accurate stratigraphic reconstructions.

[13] Fieldwork conducted as part of this project focused on mapping the geology outcropping along a $\sim 15 \mathrm{~km}$ section of the Zanskar Gorge between the villages of Nimu and Sumda (Figure 3a). The corresponding geological cross section and stratigraphy are presented in Figures $3 b$ and $3 c$, respectively. When constructing our stratigraphy, we mostly used formational names defined within previous publications (Figure 2) in order to avoid unnecessary confusion.

[14] For both the Tar and Indus Groups, we describe in turn the key facies characteristics observed within each formation. A summary of the key facies characteristics for each formation is presented in Figure 4. Associated stratigraphic logs are presented in Figure 5. This is followed by characterization of the formations in terms of their petrography, geochemical and isotopic characteristics. Finally, paleoflow data collected within this project are presented alongside previous published paleoflow data in Figure 6.

\subsection{Tar Group}

\subsubsection{Jurutze Formation}

[15] Identified as the oldest Indus Basin sedimentary unit of Late Albian [Garzanti and van Haver, 1988] to earliest Eocene (section 6.1.2) age, the Jurutze Formation is composed predominantly of black shales and siltstones, gray phyllites, and fine- to medium-grained black-gray-green sandstones, with black limestones occurring toward upper stratigraphic levels. Finer-grained lithologies dominate the lower stratigraphic levels, with commonly occurring silt, laminated mudstones and fine sandstones often showing rhythmic lamination (Figure 7a). Overall the limestones become thicker and more dominant toward the top of the Formation at the expense of other lithologies. Limestone beds are $<1 \mathrm{~m}$ to several meters thick, absent in macrofossils and often contain a large amount of quartz veining. Shales are commonly metamorphosed into blue-gray phyllites, and sandstones display a partially recrystallized texture. Pyrite is abundantly present in the black shales and gray phyllites, both of which are heavily oxidized to a brown-orange color. Deformation of the Jurutze is intense, with localized smallscale (often tight, chevron) folding and faulting preserved throughout the Formation, making the true thickness of the formation hard to determine. The southerly extent of the exposed Jurutze Formation is not displayed on Figure 3, but can be located $\sim 2 \mathrm{~km}$ north of Chilling village in the Zanskar Gorge.

\subsubsection{Sumda Formation}

[16] A continuous conformable sedimentary succession exists between the Jurutze and Sumda Formation, with the base of the Sumda Formation marked by the first occurrence of fossiliferous limestones (of Ypresian age; section 4, Figure 8) within the IBSR stratigraphy. The limestones range from black nummulitic-bioclastic wackestones and packstones, to subordinate crystalline carbonates. In addition, the Sumda Formation comprises brown-silver-gray, thinly laminated phyllites and fine- to coarse-grained sandstones commonly preserving bifurcating symmetrical ripples. Occasionally associated with the limestones are $\mathrm{dm} / \mathrm{cm}$ thick beds of brecciated mudstones with carbonate intraclasts. A $30 \mathrm{~m}$ logged stratigraphic section representative of the middle part of the Sumda Formation is presented in Figure 5a. No major folding is visible and beds mainly dip subvertically.

\subsubsection{Chogdo Formation}

[17] The relationship between the Sumda and Chogdo Formations is conformable with the base of the Chogdo Formation defined by the first occurrence of distinct redmaroon-colored well-cleaved shales (Figure 7b). Overall, the Chogdo Formation is composed of a series of fining up sedimentary sequences as displayed in Figures $5 b$ and $5 c$, typically characterized by green gritstones or conglomerates (Figure 7c), fining upward into medium- to fine-grained green sandstones and maroon shales (Figure 7d) which often contain green calcareous nodules. Sedimentary structures are generally absent from the Chogdo Formation except for occasional preserved trough cross laminations and scour marks. The Chogdo and overlying Nummulitic Limestone and Nurla formations exist in a series of steep-limbed box folds, with main fold hinges trending northwest-southeast (Figures $3 \mathrm{~b}$ and $7 \mathrm{e}$ ), and as discussed above in section 3, the development of recumbent and/or overturned saddle and canoe shaped morphologies (Figure 7b).

\subsubsection{Nummulitic Limestone}

[18] Contrary to previous suggestions of a regional unconformity [Green et al., 2008; Searle et al., 1990] we identify a conformable contact between the Chogdo and Nummulitic Limestone formations here (Figures 5d and 7f), the limestone unit dated at latest Ypresian (section 4). The

Figure 3. (a) Geological map constructed during field seasons in 2007-2009 along the Zanskar River Gorge between the villages of Sumda and Nimu. Topographic contours are displayed in $500 \mathrm{~m}$ intervals taken from Pointet [2004]. A key to the formations is provided which is also applicable to Figure 3b. Regional geography is displayed in the inset map, adapted from Mahéo et al. [2004], Robertson [2000], and Honegger et al. [1989] with study area indicated. Locations of stratigraphic logs (Figure 5) are marked (e.g., "5d"). (b) Zanskar Gorge geological cross section between points A, B, and C as displayed on the geological map in Figure 3a. Approximate locations of villages are displayed, and younging direction arrows are provided for each formation. We provide no explanation for the change in stratigraphic thicknesses observed in some units and have not invoked structural interpretations to explain these observations where no evidence of such tectonism was observed in the field. (c) Schematic stratigraphic log of the Indus Basin sedimentary rocks as deduced from the current study with age constraints taken from this study. Thrust fault locations are included. 


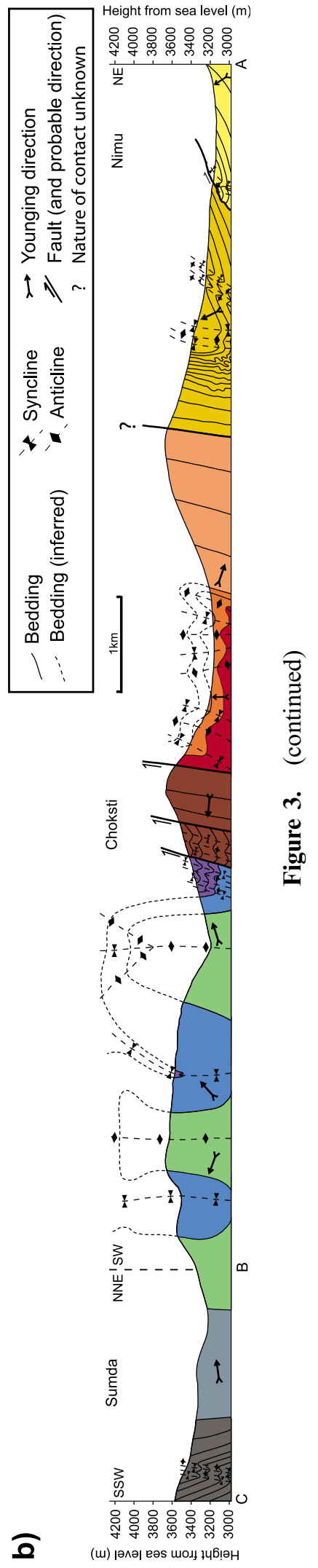

transition between the two formations is characterized by interfingering lithologies of clastic and carbonate units over a distance of 10-20 $\mathrm{m}$. Occurring $\sim 1 \mathrm{~m}$ below the base of the Nummulitic Limestone (defined at the return to carbonate deposition marked by the first crystalline carbonate bed (Figure 5d)), in the uppermost section of the Chogdo Formation, exists a pebble conglomerate unit of sedimentary lithic clasts held in a well-laminated brown sandy carbonate matrix. The conglomerate fines up into a $\sim 25 \mathrm{~cm}$ thick welllaminated, dark gray poorly lithified gritty siltstone with randomly distributed sedimentary pebble clasts. A $\sim 20 \mathrm{~cm}$ thick black, well-laminated, crystalline carbonate sits conformably above this shale which marks the base of the Nummulitic Limestone Formation. Nummulitic-bioclastic packstones and black crystalline carbonates dominate the lithology of the $>300 \mathrm{~m}$ thick Nummulitic Limestone Formation. The base of the formation is not particularly fossiliferous, being predominantly composed of well-laminated black crystalline carbonates cementing intraclasts of carbonate, clastic grits and sandstones pebbles. Toward the top of the formation, limestone gradually become less dominant and is interbedded with sandstones, black shales and pebble conglomerates; of similar lithology to the Chogdo Formation. Sandstones often contain symmetrical bifurcating ripples and black shales show evidence of both planar and ripple lamination.

\subsection{Indus Group}

\subsubsection{Nurla Formation}

[19] The conformable contact between the Nummulitic Limestone and Nurla formations is marked by the disappearance of carbonates and return of red shales and dominant coarse green to fine red sandstone, green conglomerates, and rare black shales. Despite possessing similar facies to the Chogdo, the Nurla can be distinguished by being composed of overall more proximal, coarser-grained deposits. Sandstones preserve planar and trough cross lamination, burrows, plant fossils, and red shale rip up clasts are common within lower bedding planes. The red shales have a well-developed cleavage and occasional ripple laminations. Overall the Nurla Formation shows a fining upward character (see Figure 5e) marked by the increase in thickness and dominance of red shales toward the top of the formation. Along the Zanskar Gorge, the Nurla is faulted to its north against the Choksti Conglomerate Formation.

\subsubsection{Choksti Formation}

\subsubsection{Basal Conglomerate Member}

[20] The Basal Conglomerate is faulted against both red shales of the Nurla Formation to the southwest, and the Red Shale Member to the north. This, combined with internal faulting and gentle folding suggests that its measured stratigraphic thickness is a minimum estimate. The formation is dominantly clast-supported pebble conglomerates with no evidence for clast grading (Figure 5f). Weakly preserved sporadic clast imbrication occurs, however these are likely modified by post depositional processes evident by the presence of pitted pebbles (Figure 7g). Subordinate gritty, immature, fine- to coarse-grained sandstone units often containing asymmetrical ripples and channelized or wedge shaped 

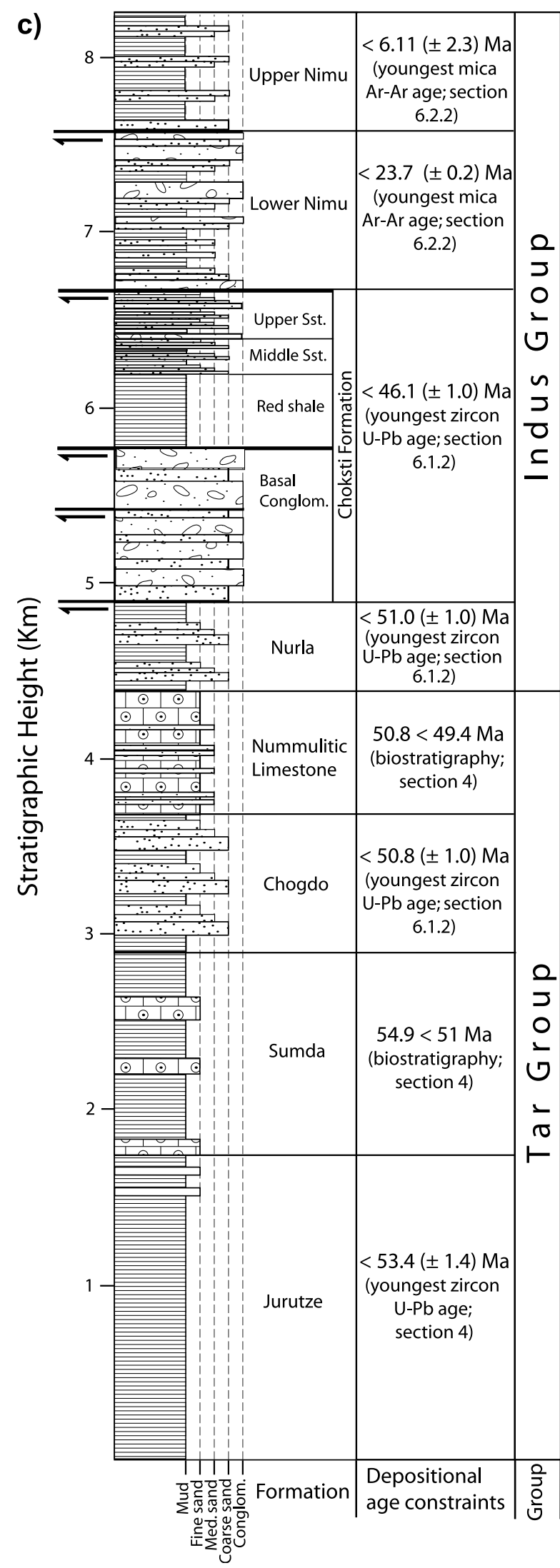

Lithological Key

Conglomerate

Sandstone

衰 Shale

임 Carbonate

Figure 3. (continued) 


\begin{tabular}{|c|c|c|c|c|c|c|c|c|c|c|c|c|}
\hline 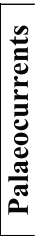 & 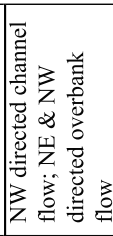 & 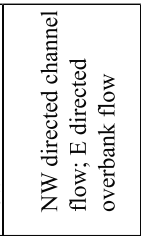 & \multicolumn{3}{|c|}{ 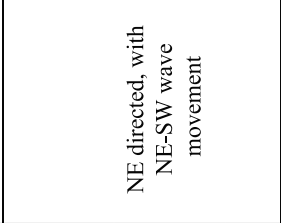 } & 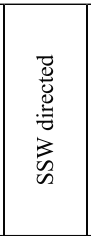 & $\underset{z}{Z}$ & 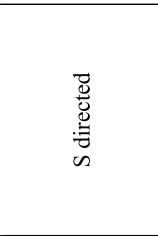 & 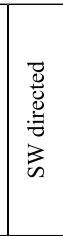 & 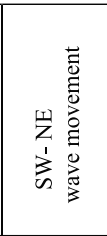 & 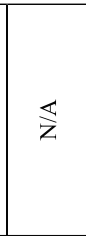 & \multirow{3}{*}{ 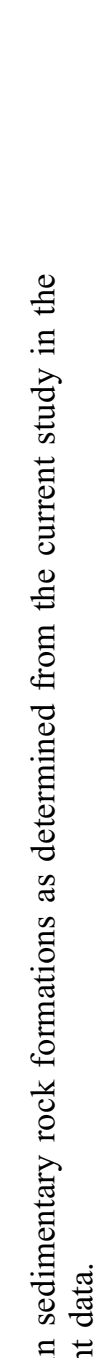 } \\
\hline & 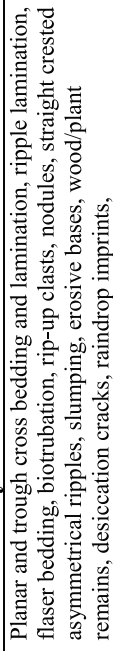 & 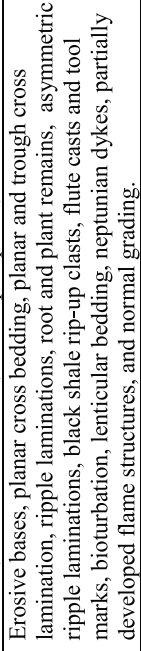 & \multicolumn{2}{|c|}{ 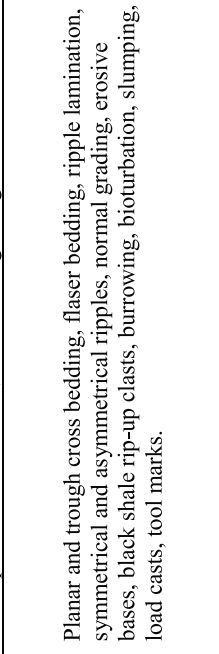 } & 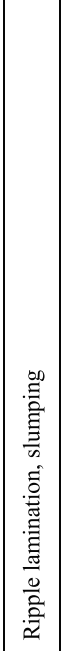 & 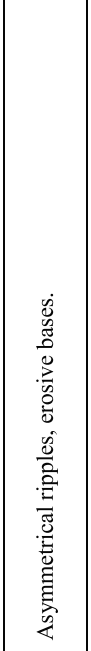 & 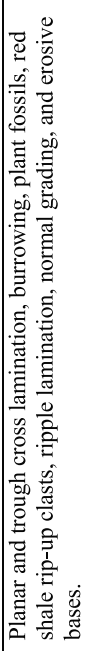 & 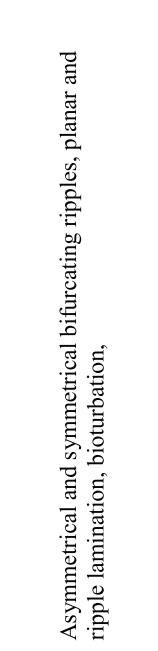 & 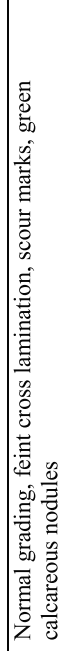 & 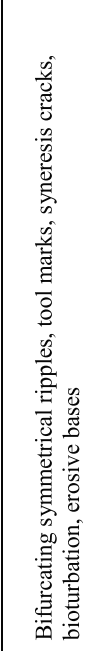 & 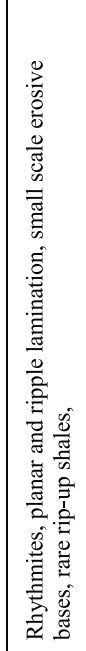 & \\
\hline 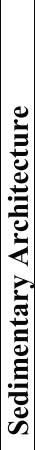 & 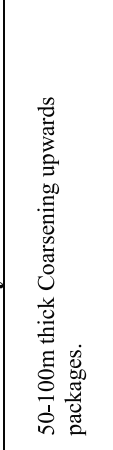 & 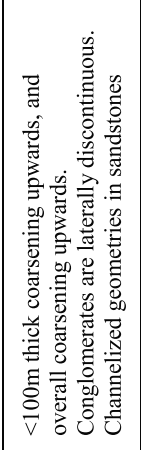 & 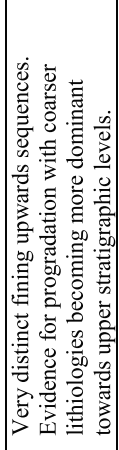 & 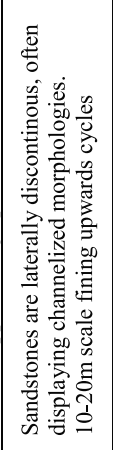 & 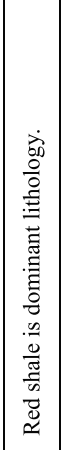 & 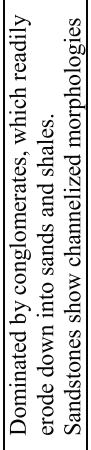 & 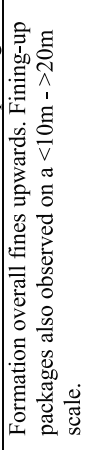 & 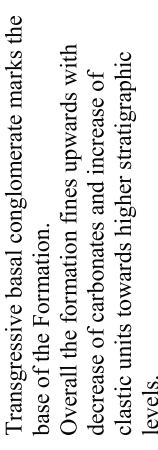 & 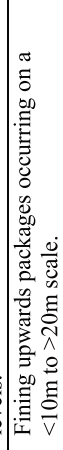 & 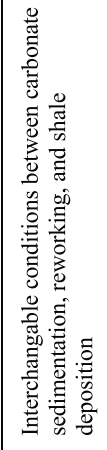 & 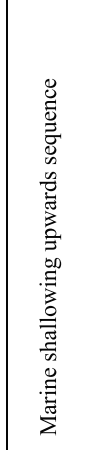 & \\
\hline & 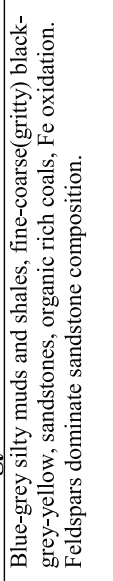 & 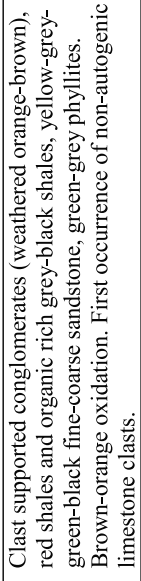 & 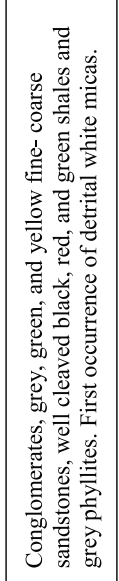 & 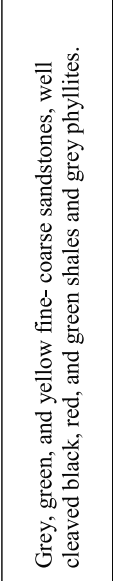 & 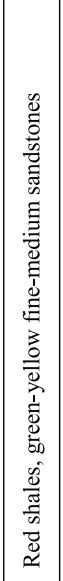 & 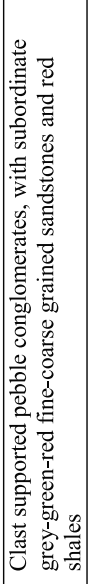 & 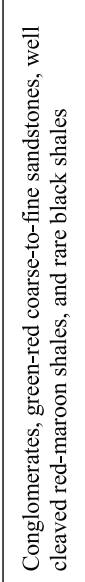 & 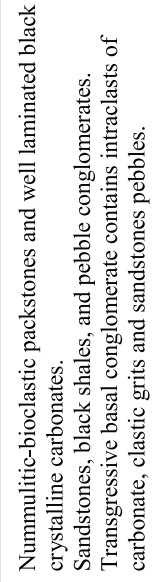 & 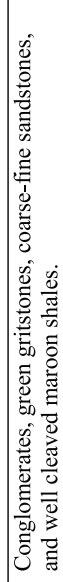 & 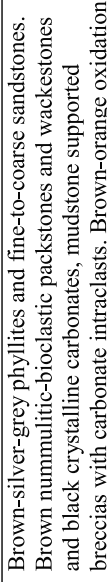 & 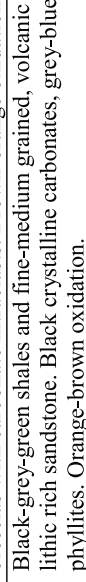 & 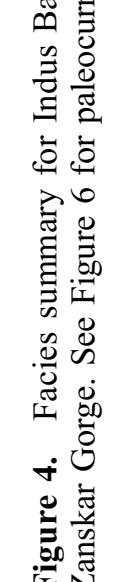 \\
\hline \multirow[t]{2}{*}{ 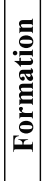 } & \multirow[t]{2}{*}{ 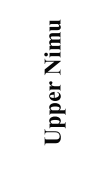 } & \multirow[t]{2}{*}{ 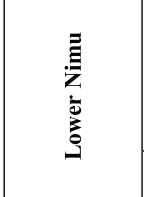 } & 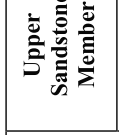 & 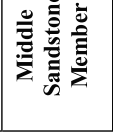 & 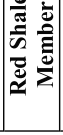 & 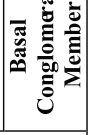 & \multirow[t]{2}{*}{$\frac{\pi}{\bar{z}}$} & \multirow[t]{2}{*}{ 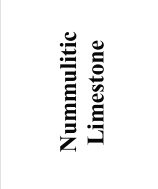 } & \multirow[t]{2}{*}{$\begin{array}{l}\stackrel{8}{\mathrm{~g}} \\
\frac{8}{0} \\
0\end{array}$} & \multirow[t]{2}{*}{ 旁 } & \multirow[t]{2}{*}{ 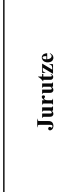 } & \\
\hline & & & & !̣s & & & & & & & & \\
\hline
\end{tabular}




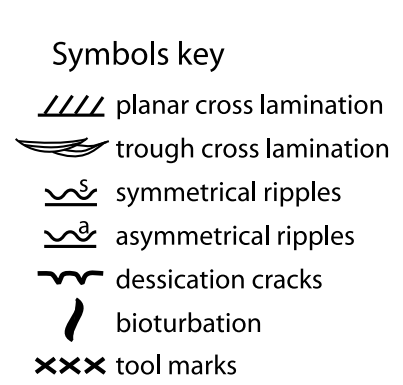

\begin{tabular}{|c|c|c|}
\hline & & $\begin{array}{l}\text { Lithology key } \\
\text { coal }\end{array}$ \\
\hline$\Longleftrightarrow$ rip up shale & $\Longleftrightarrow$ nummulites & mudstone/shale/siltstone \\
\hline$\approx$ flaser bedding & $\varnothing$ bivalves & 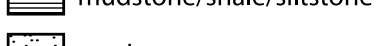 \\
\hline च slumping & $\Theta$ corals & sandstone \\
\hline$\omega$ load casts & $b$ fossils (undifferentiated) & conglomerate \\
\hline $\begin{array}{l}\approx \text { ripple lamination } \\
\approx \text { nodules } \\
\sim \text { syneresis cracks }\end{array}$ & $\begin{array}{l}\text { \& broken fossils } \\
\text { Fe Iron rich }\end{array}$ & carbonate (no fossils) \\
\hline
\end{tabular}

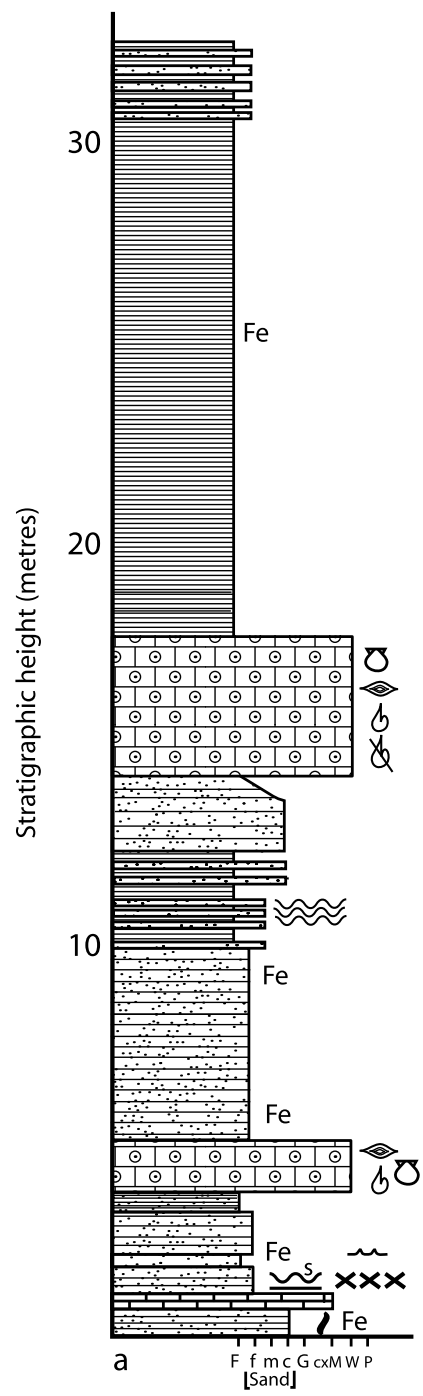

Sumda Do Formation Middle section $\mathrm{N} 34^{\circ} 06^{\prime} 13.4^{\prime \prime}$ E $077^{\circ} 12^{\prime} 43.9^{\prime \prime}$

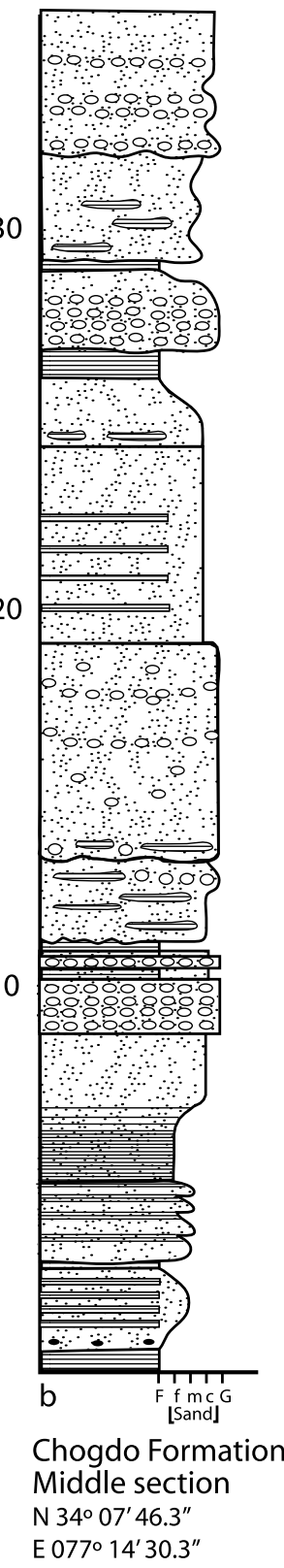

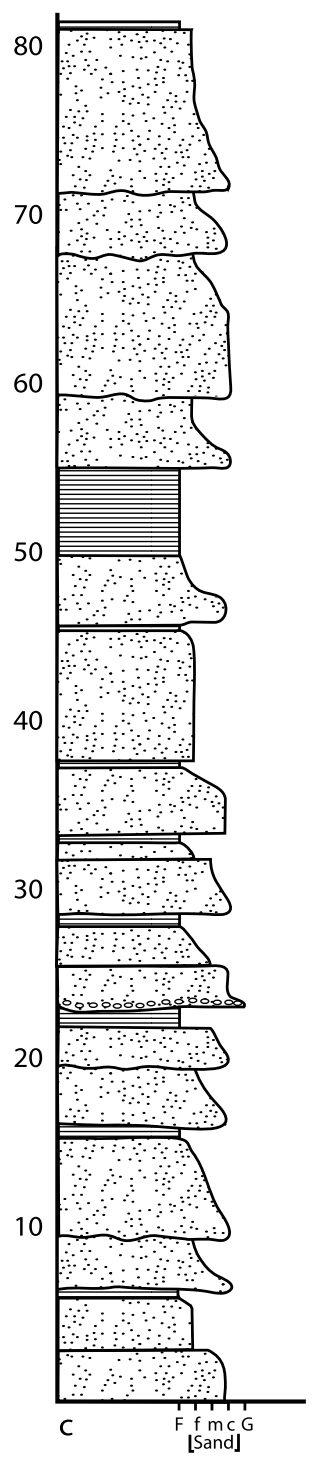

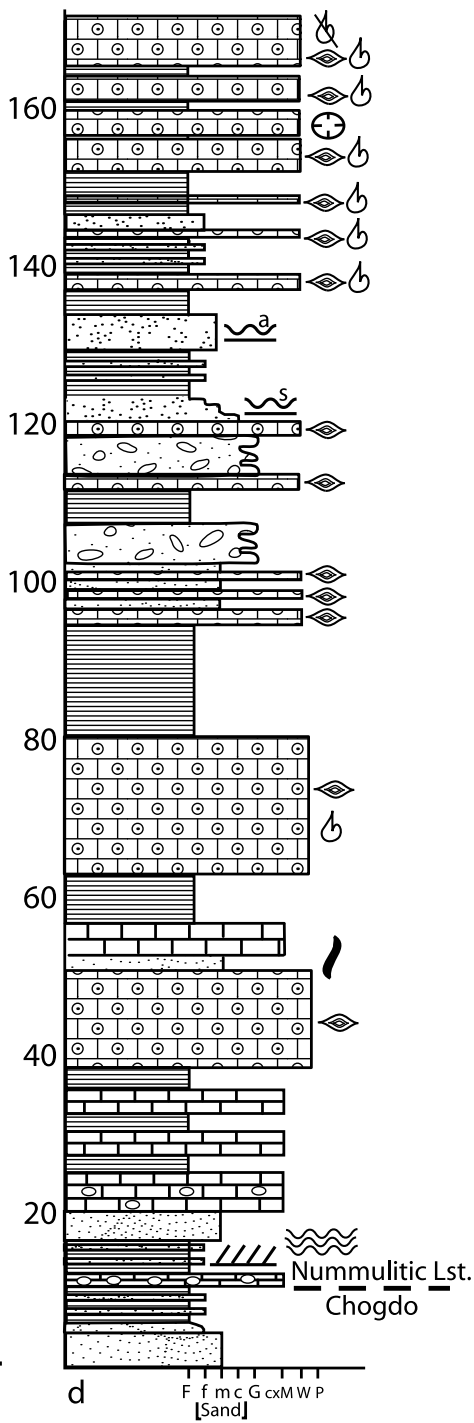

Chogdo Formation Nummulitic Limestone Upper section Lower section N 34 $06^{\prime} 45.3^{\prime \prime} \quad$ N 34 $07^{\prime} 29.6^{\prime \prime}$ E $077^{\circ} 13^{\prime} 06.6^{\prime \prime} \quad$ E $077^{\circ} 14^{\prime} 06.1^{\prime \prime}$

Figure 5. (a-1) Measured stratigraphic logs of select portions from Indus Basin sedimentary formations measured from along the Zanskar River Gorge. Location of each log is labeled on Figure 3a. Grid reference localities indicate the position of the base of each log. F, mud and fines; f, fine; m, medium; c, coarse; G, gravel (conglomerate); cxM, crystalline mudstone; W, wakestone; P, packstone. Note that scales vary between each log. See section 3.1.4 for a more detailed account of the transition between the Chogdo and Nummulitic limestone formations. 


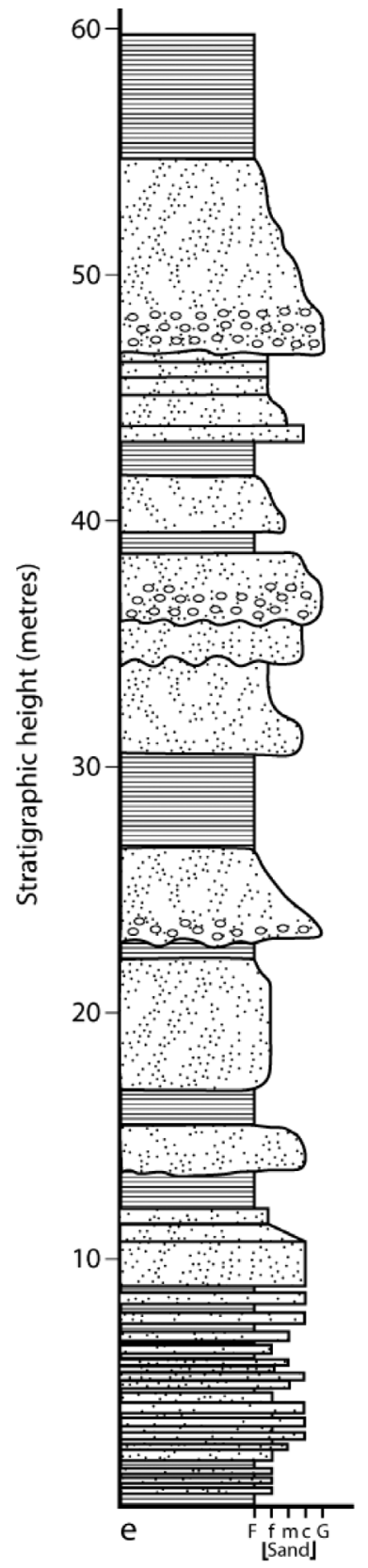

Nurla Formation Middle section $\mathrm{N} 34^{\circ} 07^{\prime} 31.0^{\prime \prime}$ E $077^{\circ} 15^{\prime} 39.5^{\prime \prime}$

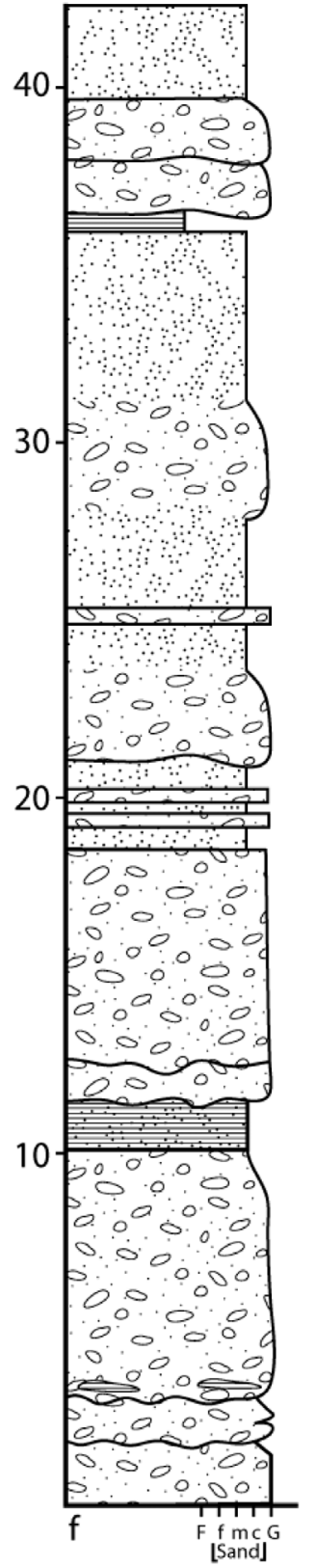

\section{Choksti Formation Basal Conglomerate Middle section $\mathrm{N} 34^{\circ} 07^{\prime} 36.9^{\prime \prime}$ E $077^{\circ} 16^{\prime} 19.6^{\prime \prime}$}

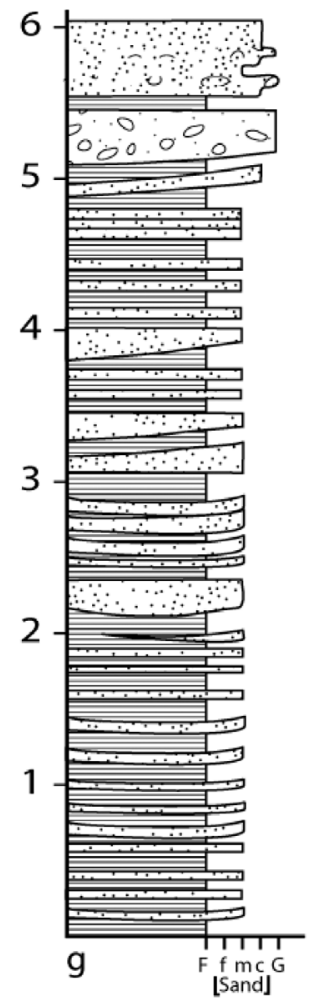

Choksti Formation Middle Sandstone Lower section N $34^{\circ} 08^{\prime} 16.3^{\prime \prime}$ $\mathrm{E} 077^{\circ} 16^{\prime} 54.0^{\prime \prime}$

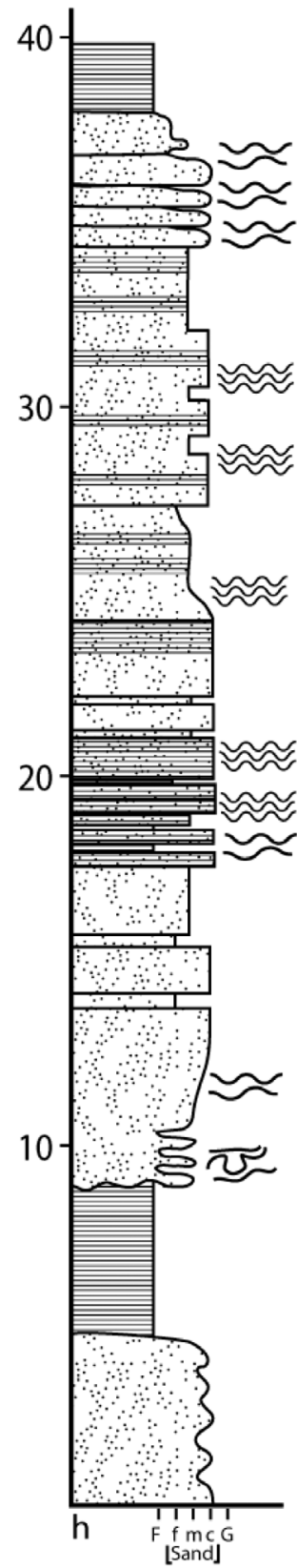

Choksti Formation Middle Sandstone Middle section N $34^{\circ} 08^{\prime} 34.5^{\prime \prime}$ E $077^{\circ} 17^{\prime} 10.6^{\prime \prime}$

Figure 5. (continued)

morphologies, are often truncated by erosive overlying conglomerates. Red shale beds $(<10 \mathrm{~m}$ thick) are also present.

\subsubsection{Red Shale Member}

[21] Composed of red shales, and green-yellow fine- to medium-grained sandstone beds, the Red Shale Member is faulted against the north side of the Basal Conglomerate.
Sandstone beds can be laterally discontinuous and both shales and sandstone show abundant ripple lamination, occasionally affected by slumping.

\subsubsection{Middle Sandstone Member}

[22] The lower portion of this conformable formation is exposed around the Choksti Road Bridge where thin 

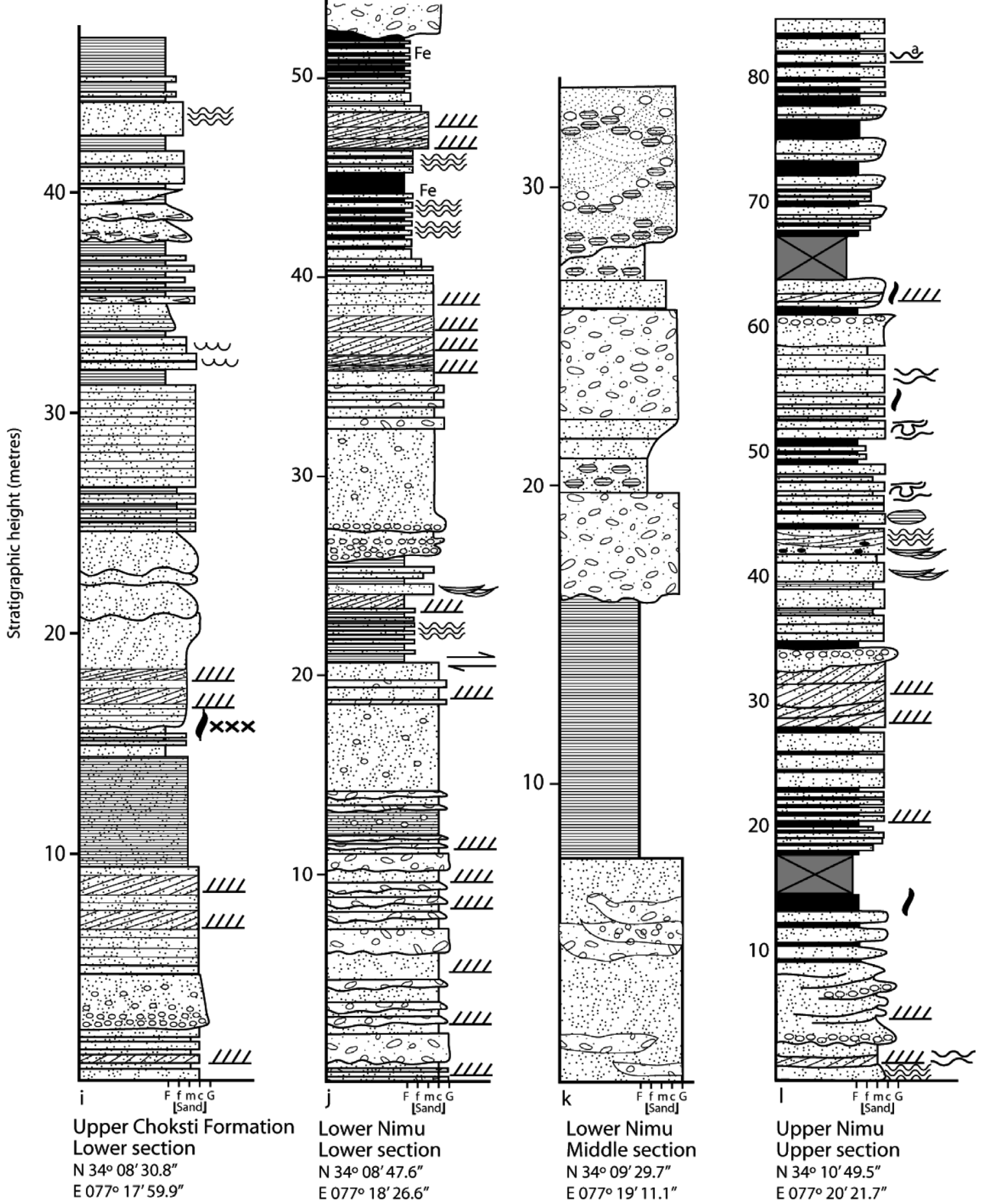

Figure 5. (continued)

$(<30 \mathrm{~cm}$ thick, $<10 \mathrm{~m}$ length) sandstone beds are interbedded with well-laminated and cleaved semiphyllitic black and gray shales (Figures $5 \mathrm{~g}$ and $7 \mathrm{~h}$ ). These units are closely associated with laterally discontinuous, well-cross bedded sandstones (Figure 7) and asymmetrical ripples are commonly preserved upon sandstone bedding planes. The main part of the Middle Sandstone Member (Figure 5h) is very similar to the Nurla Formation. Sandstones are typically gray, green, or yellow, and generally composed of mediumsized, poorly sorted, subangular sand grains. Normal grading is commonly found in the coarser-grained sandstones which often possess erosive bases and contain black shale rip-up clasts. Alongside the dominant black shales, red and green shales are also common, although they are notably 


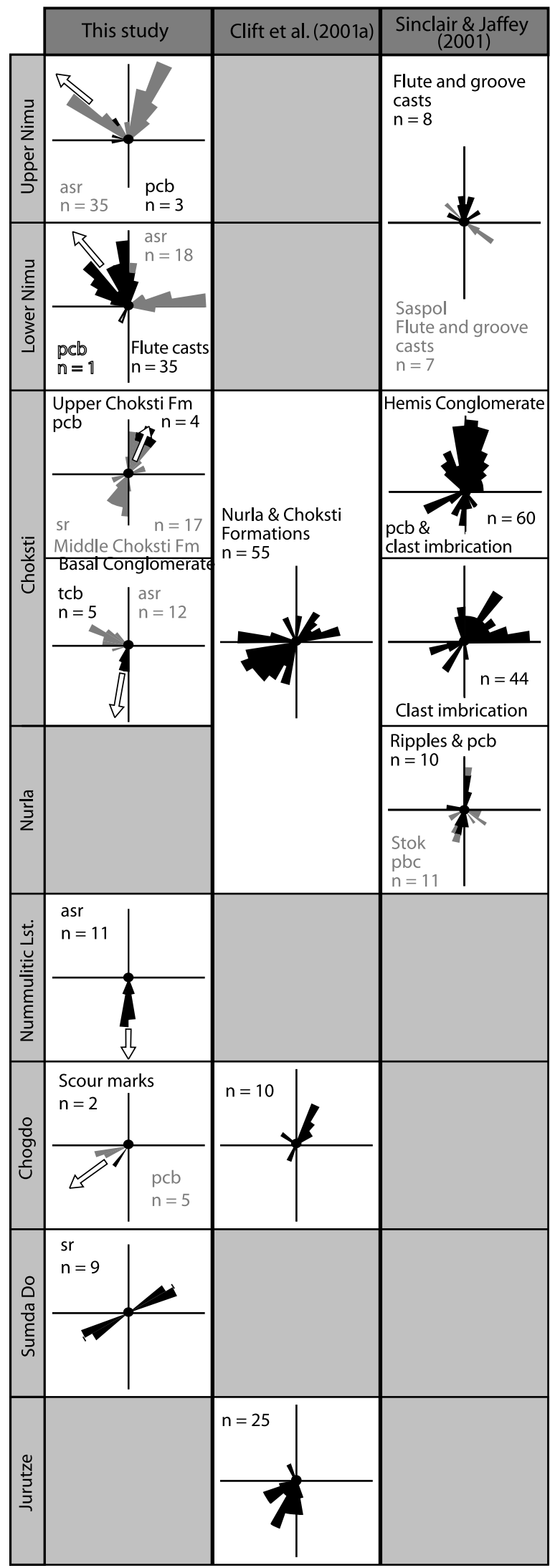

less abundant than the Chogdo and Nurla formations. Sets of fining upward cycles commonly occur on a $\sim 10-20 \mathrm{~m}$ scale, with an overall fining upward nature characteristic of the Middle Choksti Formation. Burrowing and bioturbation is common within the upper stratigraphic levels alongside the occurrence of symmetrical, wavy crested ripples. Sandstones in this upper section become light gray to light green in color and show abundant cross bedding.

\subsubsection{Upper Sandstone Member}

[23] A gradual transition in facies exists between the Middle to Upper Sandstone members with the continuation of fining up sequences of similar scale and lithology, with the contact between the two members marked by a conglomerate bed (notably absent in the Middle Sandstone Member). Fining up packages become more distinctive within the Upper Sandstone, with the base of each cycle marked by a pebble conglomerate and/or gritstone (Figure 5i), displaying erosive bases, and fining up into yellow coarse sandstones possessing infrequent lenticular morphologies. Graded bedding and trough cross bedding (displayed on a variety of scales) is abundantly apparent within the sandstones. The coarse sandstones progressively evolve up into fine yellow sandstones and well-cleaved black-gray and red shales. A progradational trend is observed with fining upward packages gradually become more dominant in coarser and thicker sandstone beds at the expense of fine-grained facies. The Red Shale, Middle, and Upper Sandstone members are altogether folded into a series of northeast verging folds. The fold limbs toward the formation's northern exposure gradually increase in steepness, eventually becoming overturned (Figure 7j). Internal faulting within the formations is also evident through a series of small-scale dextral extensional faults, and associated folds and shear zones in the lesser resistant units.

\subsubsection{Lower Nimu Formation}

[24] Previous workers [Clift et al., 2002a; Searle et al., 1990; Sinclair and Jaffey, 2001] have suggested a faulted contact between the Choksti Formation and the Lower Nimu. A direct contact between these two units was not observed in the Zanskar Gorge and we were unable to verify this, however an angular discordance in bedding between the two units suggests this contact is not conformable

Figure 6. Rose diagrams displaying tectonically restored measured paleocurrent indicators throughout the IBSR obtained from this study and work by Clift et al. [2001a] and Sinclair and Jaffey [2001]. Arrows displayed on diagrams from this study indicate dominant paleoflow directions as determined from paleocurrent indicators interpreted as representing main channel flow (e.g., cross beds and flutes) versus those interpreted as representing overbank flow (e.g., asymmetrical ripples) or wave movement in lakes or shallow marine settings (e.g., symmetrical ripples). See section 9 for a more detailed discussion. All data are measured from Zanskar Gorge unless stated otherwise: pcb, planar cross bedding; tcb, trough cross bedding; asr, asymmetrical ripples; sr, symmetrical ripples. Rose diagram section color shades correspond to the paleoflow feature written in matching color. 
(Figure $7 \mathrm{k}$ ). A typical logged stratigraphic section of the Lower Nimu Formation is presented in Figure 5k. Conglomerates are weathered a distinctive orange-brown color and subtly differ from the Basal Conglomerate, with the common association of red and black shales combined with an enriched granitoid clast presence (see section 5.2). Conglomerate beds with erosive bases are regularly seen to be laterally discontinuous (on a dm scale), terminating in
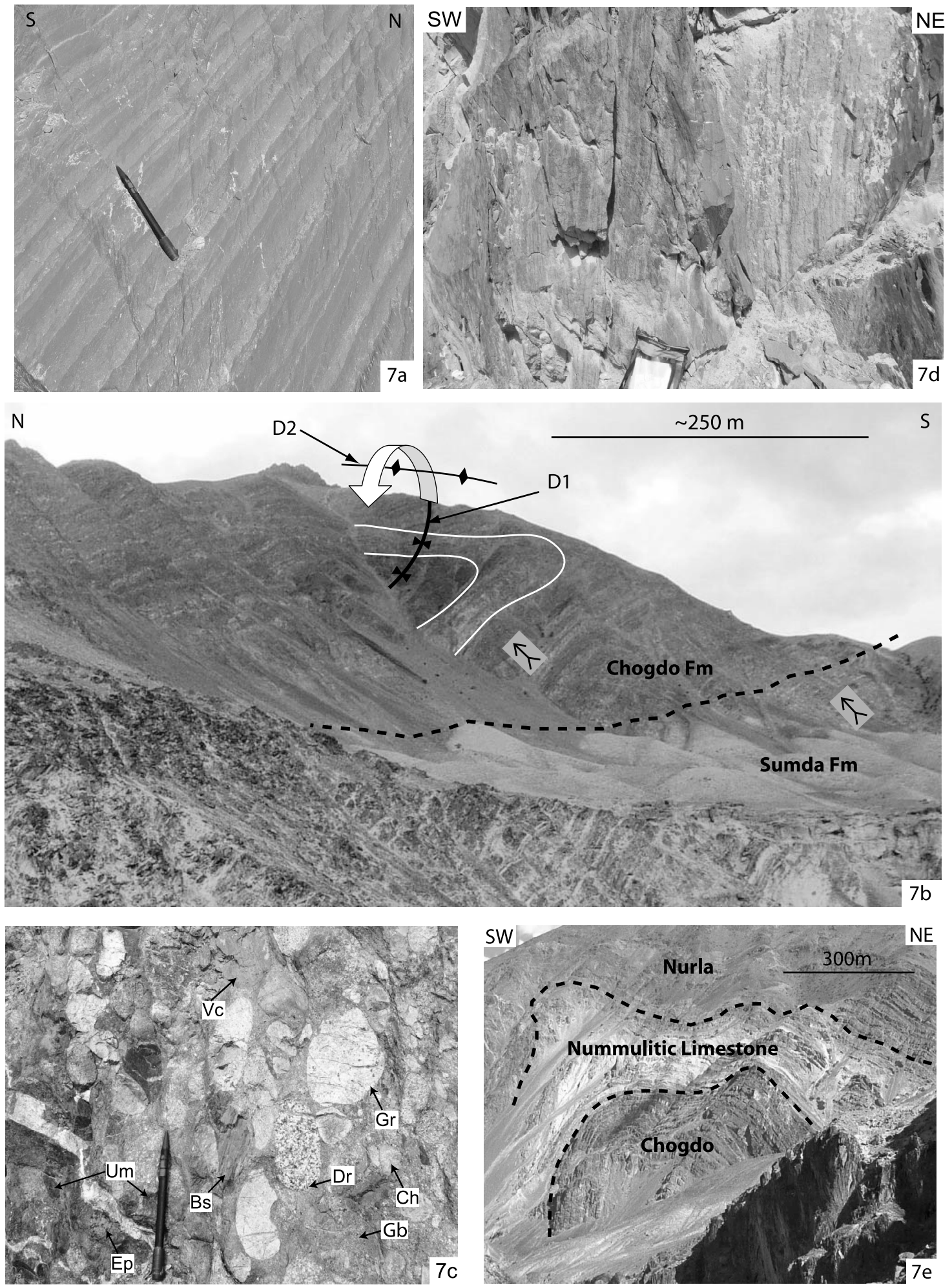

Figure 7 
subtly cross bedded subarkosic arenites and finer sediment. Coarse-grained sandstone units can display $\sim 40-10 \mathrm{~m}$ wide channelized geometries (Figure 71) which cut down into underlying, often less resistant units, occasionally composed of poorly consolidated fine-grained sandstone with an abundance of black shale rip-up clasts (Figure $7 \mathrm{~m}$ ). Finer-grained facies include organic rich, ripple laminated gray-black shales and fine-grained sandstones, occasionally preserving root and plant fossils. Gray-green coarse, angular, subimmature sandstones with sporadic cross laminations (mm-cm spacing) become more dominant within the middle and upper sections of the formation. Horizons of preserved plant remains are very common in dark gray sandstones (Figure 7n). An abundance of sedimentary structures are preserved within the mid to upper levels of the Lower Nimu: flute casts (Figure 7o) and tool marks, asymmetric ripple laminations (Figure 7p), normal grading, bioturbation, len- ticular bedding, neptunian dykes (Figure 7p), and partially developed flame structures. The sandstone varies from yellow-green-gray-black; possibly controlled by the available amount of organic material and diagenetic processes. Beds fine upward on a local ( $\sim$ subdecimeter) scale, with finer-grained lithologies ranging from shales to green-gray semiphyllitic slates. Despite this, the Lower Nimu Formation overall coarsens upward and contains $<100 \mathrm{~m}$ thick coarsening upward packages. Similar to some older formations, the Lower Nimu also shows evidence for a two phase compressional deformation history (Figure $7 q$ ).

\subsubsection{Upper Nimu Formation}

[25] The Upper Nimu is separated from the Lower Nimu by a southwest dipping fault; likely to be a northeast propagating thrust (Figure 7r). A series of fault-related folds within the Upper Nimu, in the footwall of the thrust fault, may be caused by this faulting (Figure 7r). A series of

Figure 7. (a) Shale and mudstone lamination from the Jurutze Formation, $34^{\circ} 03^{\prime} 03.5^{\prime \prime} \mathrm{N}, 077^{\circ} 12^{\prime} 41.0^{\prime \prime} \mathrm{E}$. (b) Conformable contact between the Sumda and Chogdo formations. Red shales of the Chogdo Formation depict edge of recumbent saddle fold morphology, a result of secondary (D2) northwest-southeast compression. Taken from $34^{\circ} 06^{\prime} 14.39^{\prime \prime} \mathrm{N}, 077^{\circ} 12^{\prime} 51.84^{\prime \prime} \mathrm{E}$. (c) Typical composition of conglomerate clasts from the Chogdo Formation. Taken from $34^{\circ} 07^{\prime} 46.3^{\prime \prime} \mathrm{N}, 077^{\circ} 14^{\prime} 30.3^{\prime \prime} \mathrm{E}$. Clasts: Gr, granitoid; Dr, diorite; Vc, volcanic; Ch, chert; Bs, black shale; Um, ultramafic; Ep, epidote altered clast; Gb, gabbro. (d) Outcrop of subvertically dipping beds of the Chogdo Formation showing alternating fine-medium green sandstone with maroon fine sand-mudstone and overall showing a lack of preserved sedimentary structures. Younging direction is toward the southwest. Taken from $34^{\circ} 07^{\prime} 46.3^{\prime \prime} \mathrm{N}, 077^{\circ} 14^{\prime} 30.3^{\prime \prime} \mathrm{E}$. (e) Box fold of Chogdo, Nummulitic Limestone, and Nurla formations taken from $34^{\circ} 07^{\prime} 44.0^{\prime \prime} \mathrm{N}, 077^{\circ} 14^{\prime} 30.3^{\prime \prime} \mathrm{E}$. (f) Conformable transition between the Chogdo and Nummulitic Limestone formations. Black dashed lines depict bedding boundaries. Dashed white and black line indicates ChogdoNummulitic Limestone contact. Taken from 34 $7^{\prime} 17.62^{\prime \prime} \mathrm{N}, 077^{\circ} 13^{\prime} 53.66^{\prime \prime} \mathrm{E}$. (g) Pitted pebbles from the Indus Group. Arrow depicts pitted, fused pebble contact. Taken from $\sim 2 \mathrm{~km}$ south of Upshi; $33^{\circ} 47^{\prime} 56.0^{\prime \prime} \mathrm{N}, 077^{\circ} 47^{\prime} 36.3^{\prime \prime} \mathrm{E}$. (h) Base of the Choksti Formation (Middle Sandstone Member). Thinly bedded sandstones interbedded with cleaved black shale, interpreted as crevasse splay deposits. From $34^{\circ} 08^{\prime} 24.21^{\prime \prime} \mathrm{N}, 077^{\circ} 17^{\prime} 02.91^{\prime \prime}$. (i) Base of the Middle Sandstone Member (Choksti Formation); point bar deposits showing fluvial lateral accretion toward approximately west. Taken from $34^{\circ} 08^{\prime} 24.21^{\prime \prime} \mathrm{N}, 077^{\circ} 17^{\prime} 02.91^{\prime \prime} \mathrm{E}$. (j) Middle and Upper Sandstone members of the Choksti Formation. Stratigraphic contact is not visible. Black dashed line depicts randomly chosen marker bed in the Upper Sandstone to illustrate fold pattern. Taken from $34^{\circ} 08^{\prime} 32.67^{\prime \prime} \mathrm{N}$, $077^{\circ} 17^{\prime} 27.39^{\prime \prime}$ E. (k) Angular discordance in bedding between the Upper Sandstone Member of the Choksti Formation and Lower Nimu Formation Bedding planes is depicted by dashed white lines. Arrows indicate younging direction. Approximate location of contact boundary is marked by a dashed black line. Taken from $34^{\circ} 08^{\prime} 47.6^{\prime \prime} \mathrm{N}, 077^{\circ} 18^{\prime} 26.5^{\prime \prime} \mathrm{E}$. (l) Lenticular sandstone in the Lower Nimu Formation, interpreted as a channel fill. Erosive channel base is depicted by a white line (dashed where inferred). Marginal channel bedding is indicated by the white dotted lines. Bedding of fine-grained sandstones and shales, representative of overbank deposits, is depicted by the black dashed lines and is truncated by channel sandstones. Bidirectional channel axis trend is measured at a $119^{\circ}-299^{\circ}$ angle; however, this likely reflects flow toward $299^{\circ}$ as evidenced by northwest directed paleoflow measurement from flute casts associated with the channelized sand body. Photo taken from $34^{\circ} 09^{\prime} 34.7^{\prime \prime} \mathrm{N}, 077^{\circ} 19^{\prime} 18.0^{\prime \prime} \mathrm{E}$. (m) Lower Nimu Formation lenticular channel fill sandstone beds and fine-grained sandstone with abundant black shale and sandstone rip-up clasts (mostly weathered out and now represented by the dark depressions). Channel axes trend southeast-northwest. Taken from $34^{\circ} 09^{\prime} 23.17^{\prime \prime} \mathrm{N}, 077^{\circ} 18^{\prime} 56.40^{\prime \prime} \mathrm{E}$. (n) Wood and plant remains from the Lower Nimu Formation. Taken from $34^{\circ} 09^{\prime} 10.48^{\prime \prime} \mathrm{N}, 077^{\circ} 18^{\prime} 52.49^{\prime \prime} \mathrm{E}$. (o) Flute casts within the Lower Nimu Formation, providing a north-northwest flow paleoflow direction. Taken from $34^{\circ} 09^{\prime} 10.48^{\prime \prime} \mathrm{N}, 077^{\circ} 18^{\prime} 52.49^{\prime \prime} \mathrm{E}$. (p) Asymmetric ripple and planar lamination, small-scale neptunian dykes, and load structures from the Lower Nimu Formation. Paleoflow is directed toward the north. Taken from $34^{\circ} 09^{\prime} 12.8^{\prime \prime} \mathrm{N}, 077^{\circ} 18^{\prime} 54.3^{\prime \prime} \mathrm{E}$. (q) Folded beds within the Lower Nimu Formation. Thick black dashed line depicts marker bed. D1 syncline fold axis results from original northeast-southwest compression. D2 anticline fold axis represents a later northwest-southeast compressional event. Taken from $34^{\circ} 09^{\prime} 09.5^{\prime \prime} \mathrm{N}, 077^{\circ} 18^{\prime} 52.1^{\prime \prime} \mathrm{E}$. (r) Possible northeast propagating thrust emplacing the Lower Nimu over the younger Upper Nimu Formation. Probable fault-related folds are visible in the Upper Nimu in the footwall of the thrust. Taken from $34^{\circ} 09^{\prime} 56.87^{\prime \prime} \mathrm{N}$, $077^{\circ} 19^{\prime} 59.30^{\prime \prime}$. (s) Coarsening upward cycles in the Upper Nimu Formation. Black shales are likely to underlie the scree. See sedimentary log (Figure 51) for facies detail. Taken from 340 $10^{\prime} 25.1^{\prime \prime} \mathrm{N}, 077^{\circ} 20^{\prime} 12.1^{\prime \prime}$ E. (t) Unconformable relationship of the Upper Nimu Formation overlying the Ladakh Batholith, taken from near the village of Karu, $40 \mathrm{~km}$ southwest of Nimu, 33 $53^{\prime} 19.16^{\prime \prime} \mathrm{N}, 077^{\circ} 44^{\prime} 59.88^{\prime \prime} \mathrm{E}$. An example of a coarsening upward cycle typically characteristic throughout the Upper Nimu Formation is also highlighted. 

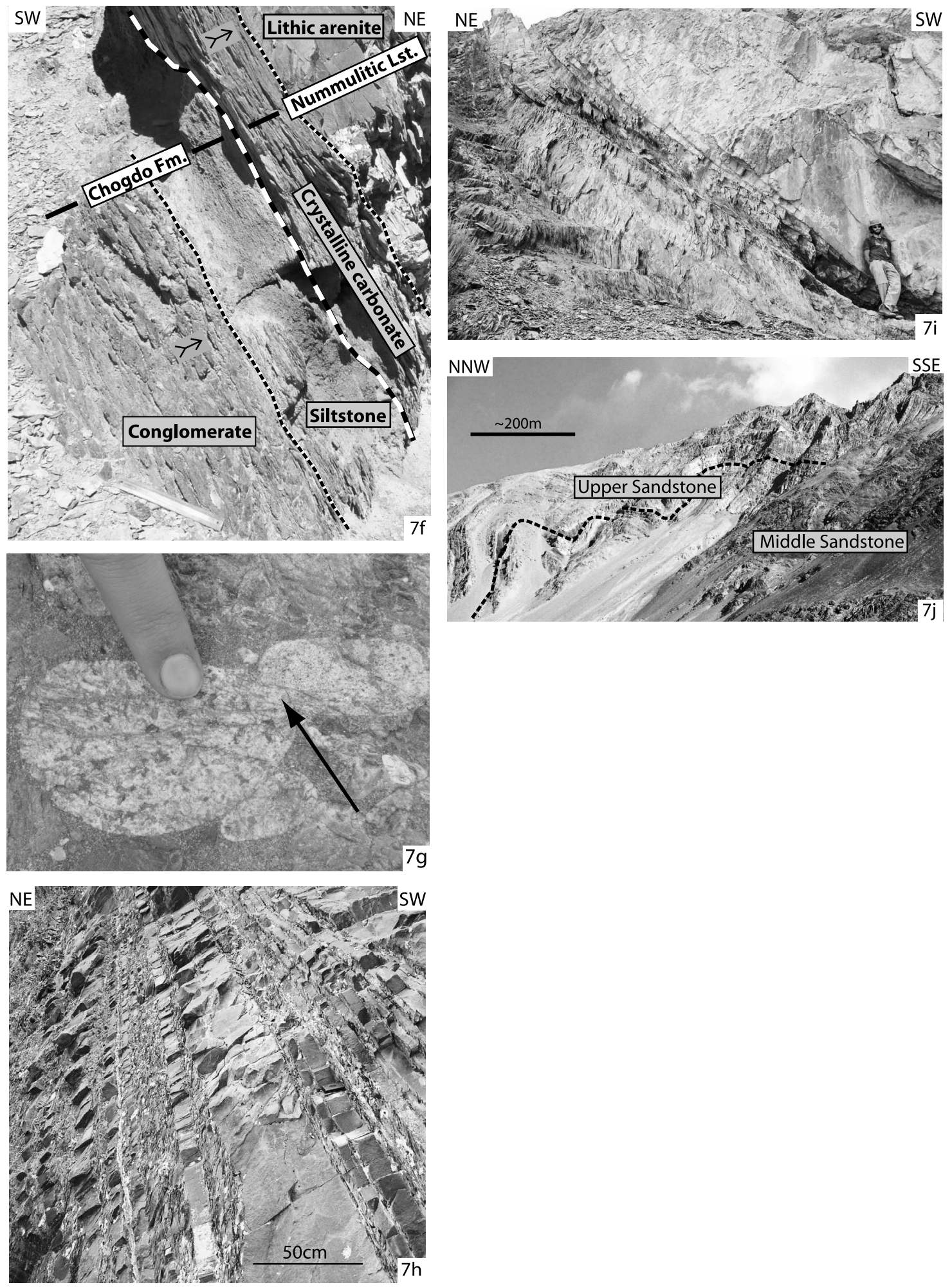

Figure 7. (continued)

coarsening upward sedimentary cycles (Figure 7s) dominate the formation as displayed in Figure 51. The base of each coarsening package begins with blue-gray silty muds and shales, which gradually become less abundant with increasing stratigraphic height, matched by the associated increase in gray-yellow gritty, sandstones with gentle erosive bases and well-developed trough and planar cross beds. Sandstones show gradual fine to coarse grain size 

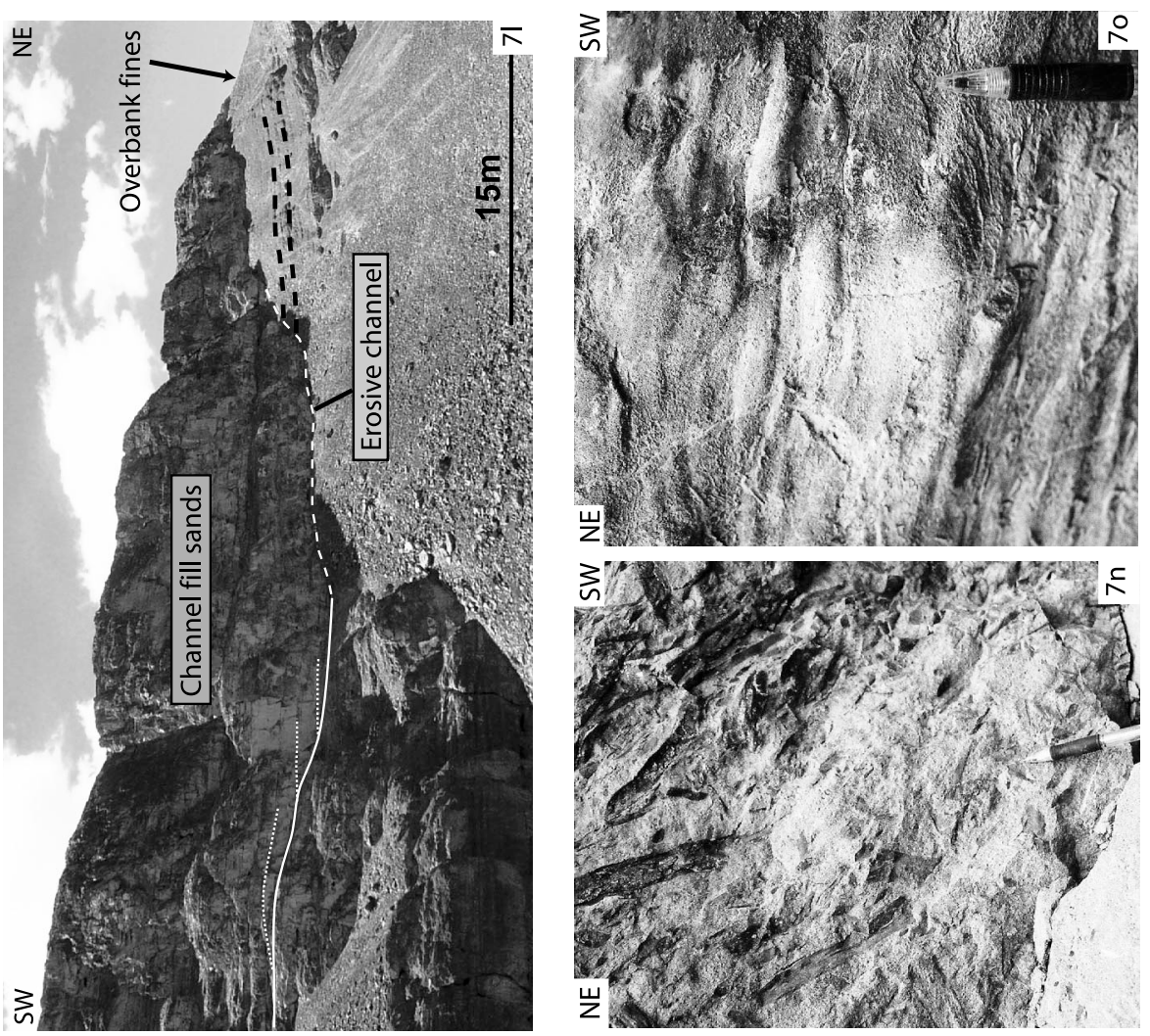

م્0
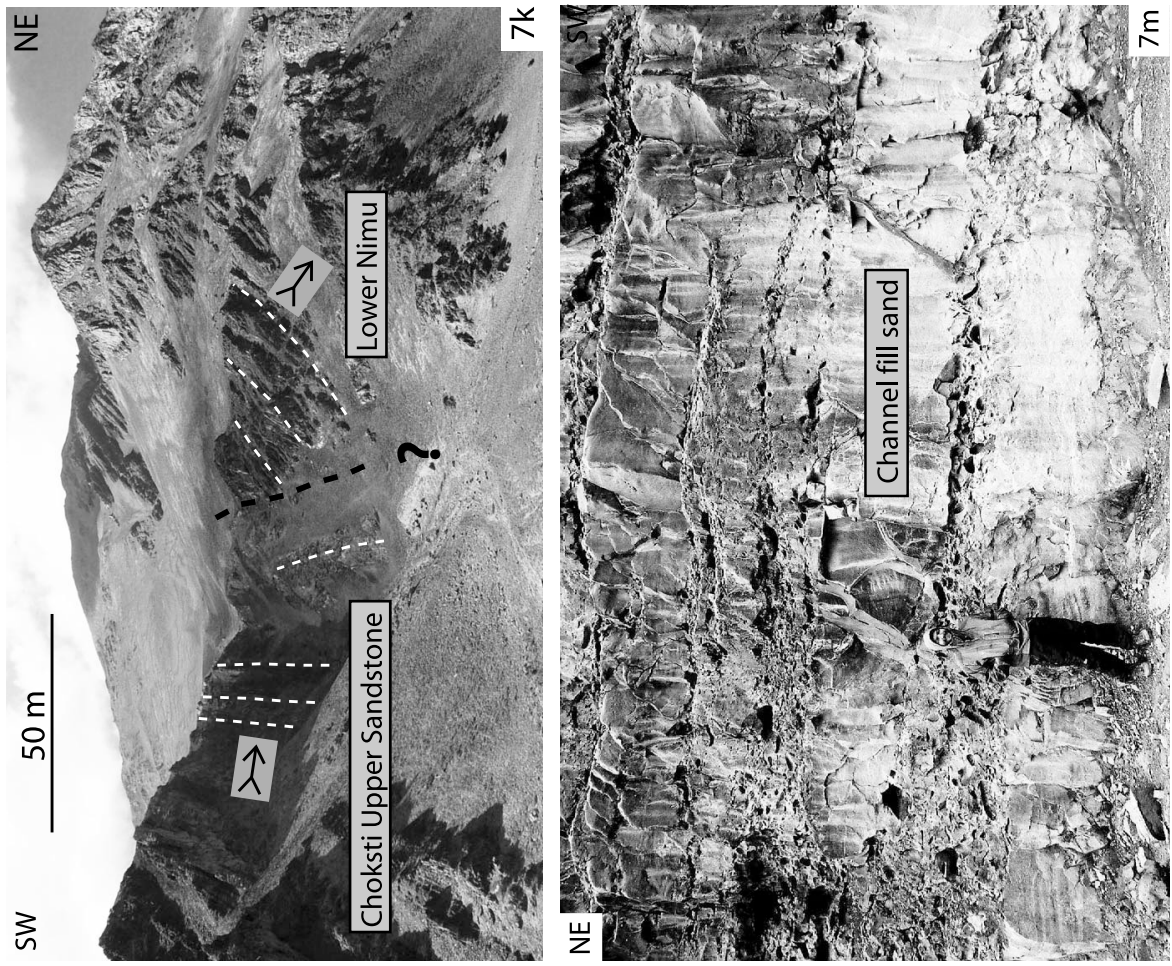

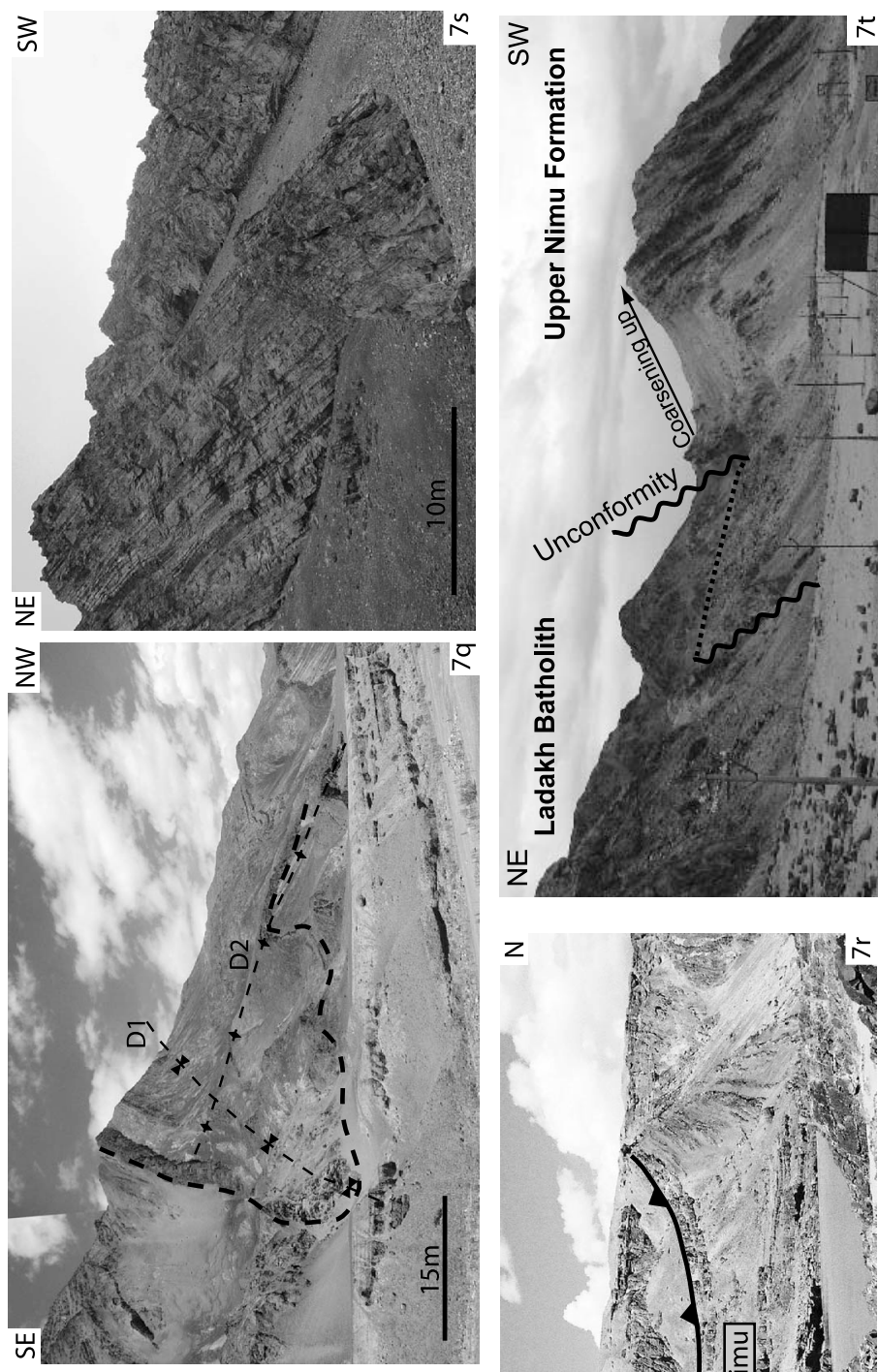

氖
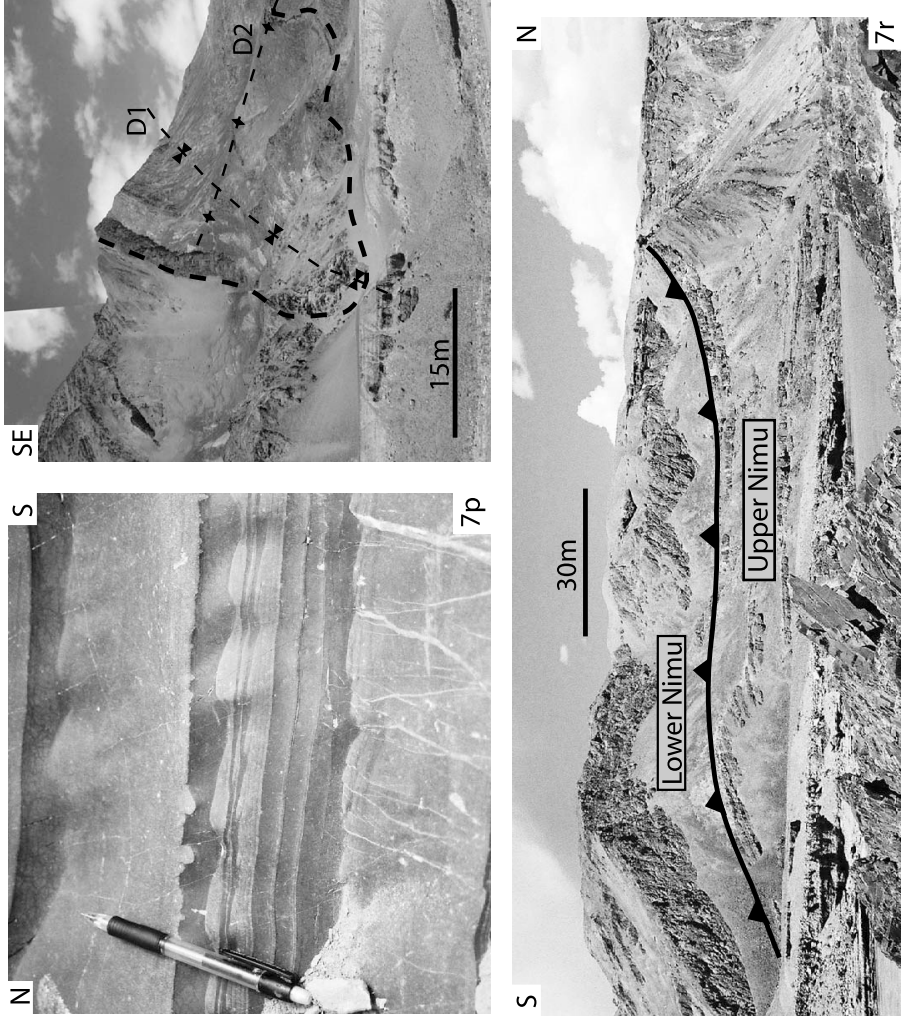


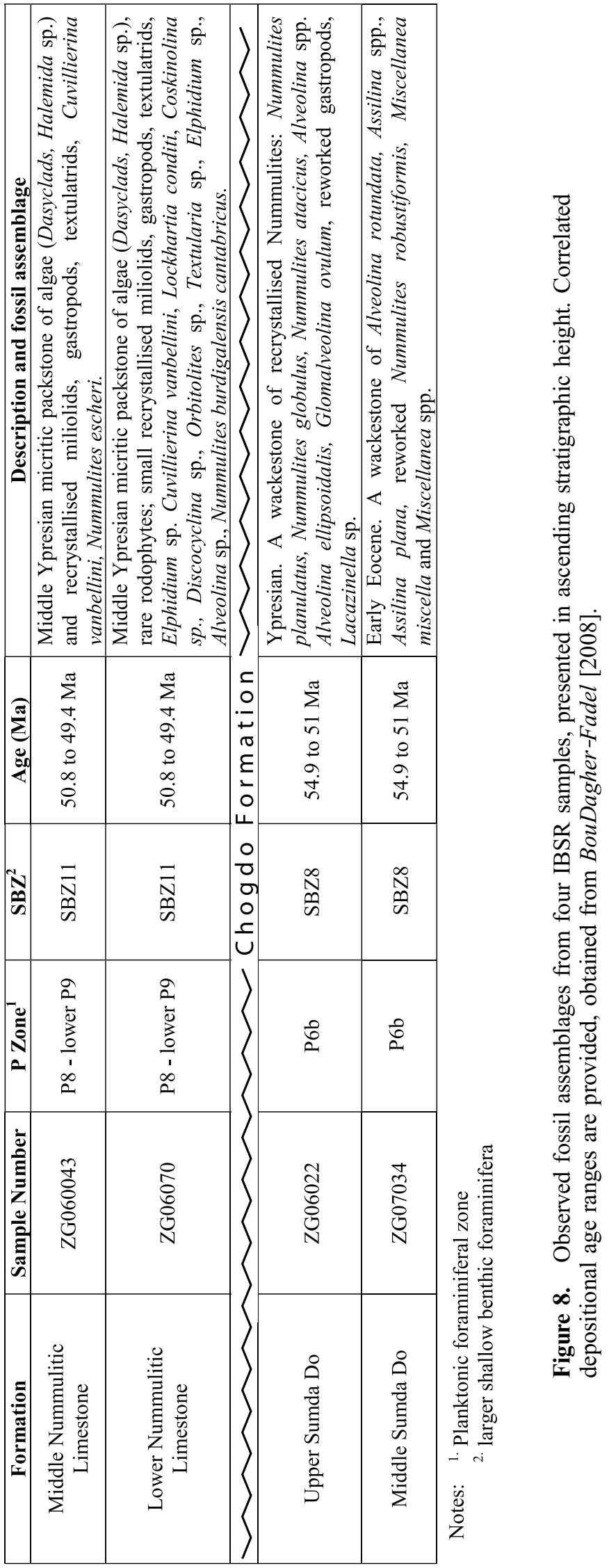


variations over a $\sim 1 \mathrm{~m}$ scale, and are occasionally interbedded with $1-5 \mathrm{~cm}$ thick beds of fine sandstone, gray shale, or organic rich coals often containing wood fragments. Black sandstones are present which often contain iron oxidation, whereas red shales are notably absent from the Upper Nimu. Sedimentary structures commonly preserved include desiccation cracks, straight crested and lunate ripples, raindrop imprints, and rip-up shales. The Upper Nimu Formation is juxtaposed against the south side of the Ladakh Batholith (Figure 7t), however the contact between these two units is not exposed within the area immediately surrounding Nimu, with the first exposure of the batholith outcropping $\sim 5 \mathrm{~km}$ due north of the Indus-Zanskar River confluence.

\section{Biostratigraphy}

[26] Previous stratigraphic age estimates of the Indus Group have been hampered by the overall lack of preserved fossil assemblages. van Haver [1984] identified palm leaves and bivalves within the mid-upper section of the Indus Group to yield an upper Eocene-lower Oligocene age. Furthermore, van Haver [1984] also identified Maastrichtian aged ostracods in the northern Indus Group; however, Searle et al. [1990] suggested that these ostracods were reworked, thus not reflecting the true depositional age of the sediments. The most reliable biostratigraphic age constraints which can be obtained from the IBSR come from the wellpreserved fossils within the Tar Group. Limestones from the upper Sumda Formation were originally assigned a Paleocene age by van Haver [1984], based on gastropods and bivalves. However, a more recent biostratigraphic study by Green et al. [2008] suggested that the Sumda Formation was deposited during Planktonic Foraminiferal Zone (P) P4c to lower P5, allowing the authors to suggest that Sumda limestone deposition terminated during the Upper Paleocene; $56.5-54.9 \mathrm{Ma}$ (in accordance with the time scale of Berggren et al. [1995]), marking the end of continuous marine sedimentation within the Indus Basin. Originally the Nummulitic Limestone Formation was assigned to an early mid Eocene age by van Haver [1984] dated at 49 Ma, with the more recent work of Green et al. [2008] proposing a Cuisian-Ypresian depositional age of $50.5 \mathrm{Ma}$ (equivalent to P8, and shallow benthic zone (SBZ) SBZ10; in accordance with the time scale of Berggren et al. [1995]).

[27] The results of biostratigraphic analysis of four IBSR samples conducted as part of this study are presented in Figure 8. Sample ZG07034 from the middle stratigraphic levels of the Sumda Formation (Figures 8 and 9) contains a largely reworked fossil assemblage, disallowing the assignment of a precise depositional age. However, the presence of Alveolina rotundata Hottinger (an Early Eocene form, P6 planktonic foraminiferal zone/SBZ8 to SBZ9 shallow benthic zones) in sample ZG07034 with the combined presence of Nummulites atacicus, Nummulites planulatus and Alveolina ellipsoidalis (Figures 8 and 9) in sample ZG06022 from the upper stratigraphic levels of the Sumda Formation imply a depositional age of P6b (SBZ8) at around 54.9 to $51 \mathrm{Ma}$ [BouDagher-Fadel, 2008; Gradstein et al., 2004]. Biostratigraphic analysis of samples ZG07043 and ZG07070 from the Nummulitic Limestone Formation identified the pre- sence of Nummulites escheri and Cuvillierina vanbellini (Figures 8 and 9) assigning the formation to P8-lower P9 (SBZ11) with an age range of 50.8 to $49.4 \mathrm{Ma}$, based on the time scale of Gradstein et al. [2004], marking the age of the last observed marine occurrence in the Indus Suture Zone. Further age constraints, complementary to the biostratigraphic data, are determined from radiometric age dating of detrital minerals, as given in section 6 .

\section{Composition}

\subsection{Sandstone Petrography}

[28] To help characterize the formations and to assess any evolutionary compositional changes to the Indus Basin detrital petrography, a total of 14 medium-grained sandstone samples were thin sectioned and analyzed in order to confirm and expand upon existing data from these formations [Garzanti and van Haver, 1988]. For each sample $>300$ orderly spaced points were counted using the GazziDickinson method [Dickinson, 1985; Ingersoll et al., 1984], enabling proportions of the different minerals present to be established. Full results are displayed in Data Set S1 and are presented in a provenance discrimination plot based on quartz, feldspar, and lithic proportional composition [Dickinson and Suczek, 1979] (Figure 10). ${ }^{1}$ Within all of the samples analyzed, volcanic lithic fragments make up the dominant component of total lithic presence. A detailed account of the nature of volcanic lithics present throughout the IBSR stratigraphy is provided by Garzanti and van Haver [1988]. Volcanic lithic fragments, predominantly fine-grained intermediate volcanics, dominate the total compositional framework in the older IBSR (Tar Group) formations. Toward upper stratigraphic levels in the Indus Group, felsic plutonic lithic fragments, quartz and feldspar become increasingly common at the expense of volcanic lithics. Metamorphic lithic fragments of quartzite are present in relatively low abundance in the Lower Nimu (ZG06021) and Choksti Formation's Upper Sandstone Member (ZG06028) samples. The feldspathoquartzose arenites of the Choksti Formation's Upper Sandstone Member show the first occurrence within the Indus Group where detrital white micas are preserved, with the Nimu Formation containing an even greater abundance of detrital white micas.

[29] Heavy mineral analysis was conducted on two samples from the Nummulitic Limestone and Choksti Formation's Upper Sandstone Member (Data Set S2). Detrital biotite, titanite and blue-green hornblende were present in the Upper Sandstone Member, whereas the latter two minerals were absent from the Nummulitic Limestone. These results are also reflected in thin section, in agreement with Clift et al. [2001a], who found hornblende to only occur in significant abundance in post Choksti Basal Conglomerate deposits, with biotite present throughout the section but decreasing in abundance upsection. We found diagenetic chlorite and epidote present in both our analyzed samples, and we acknowledge the strong possibility that true abundances

\footnotetext{
${ }^{1}$ Auxiliary material data sets are available at $\mathrm{ftp}: / / \mathrm{ftp}$.agu.org/apend/tc/ 2009tc002651. Other auxiliary material files are in the HTML.
} 

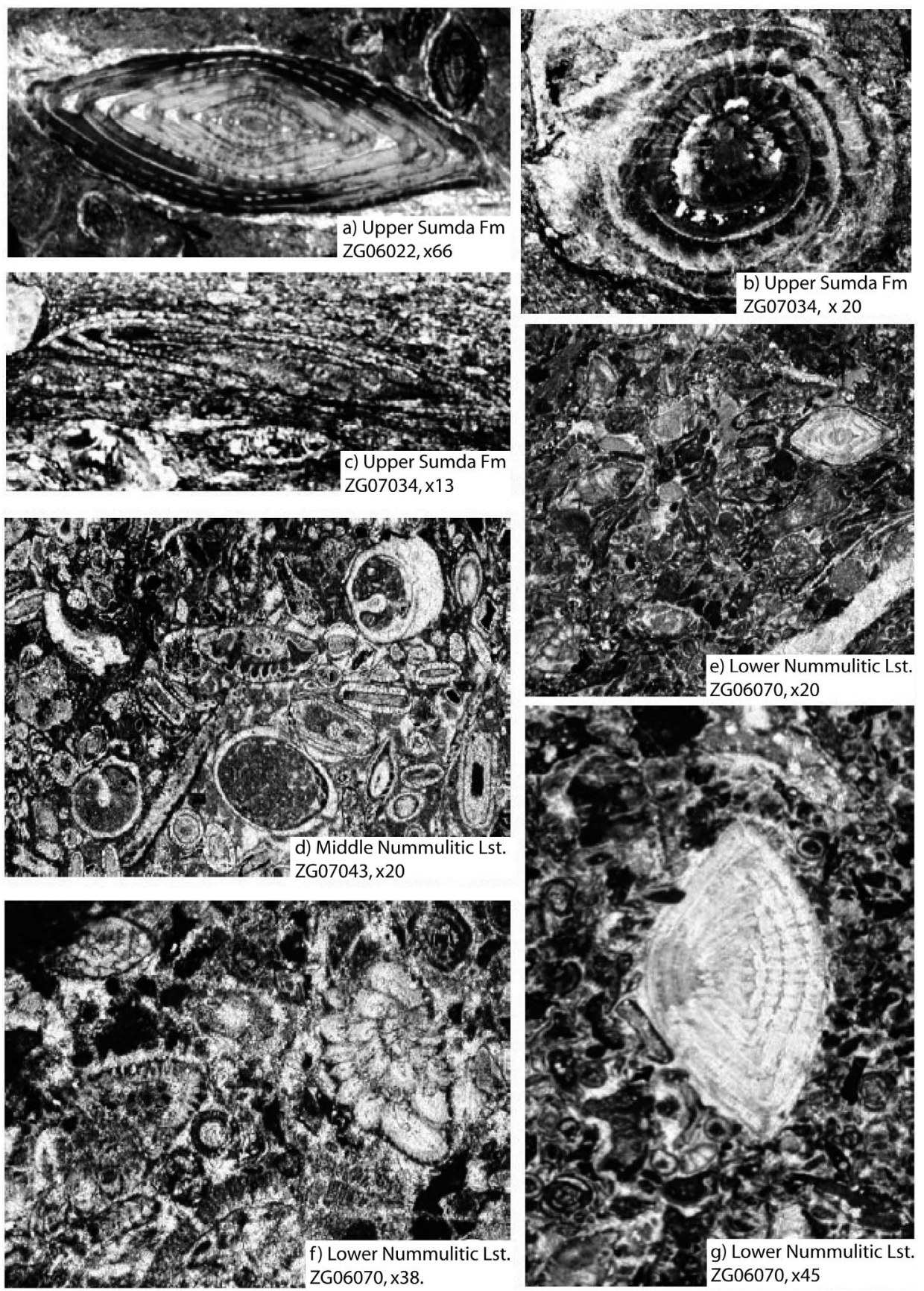

Figure 9. Thin section photomicrographs of microfossils from both the Sumda and Nummulitic Limestone formations. (a) Nummulites atacicus Leymerie (axial section): SBZ8, P6. (b) Reworked Nummulites robustiformis Schaub (equatorial section), late Paleocene Thanetian: SBZ7, P4-P5. (c) Alveolina rotundata Hottinger (SBZ8-SBZ9, P6) and reworked Miscellanea miscella (d'Archiac and Haime) (SBZ7, P4-P5). (d) Cuvillierina vanbelleni Grimsdale: SBZ11, P8-lower P9. (e) Nummulites burdigalensis cantabricus Schaub, megalospheric form, miliolids, textulariids, and fragments of algae: SBZ11, P8-lower P9. (f) Cuvillierina vanbelleni Grimsdale: SBZ11, P8-lower P9. (g) Nummulites burdigalensis cantabricus Schaub, megalospheric form: SBZ11, P8-lower P9.

of unstable heavy minerals (e.g., pyroxene and amphibole) may have been strongly affected by digenesis. On this basis, we considered further heavy mineral analyses were unlikely to be productive.

\subsection{Conglomerates}

[30] A total of ten clast counts were conducted on conglomerates present throughout the IBSR and the results are displayed in Figure 11. In agreement with the work of 
$\diamond$ Upper Nimu $\quad$ Q

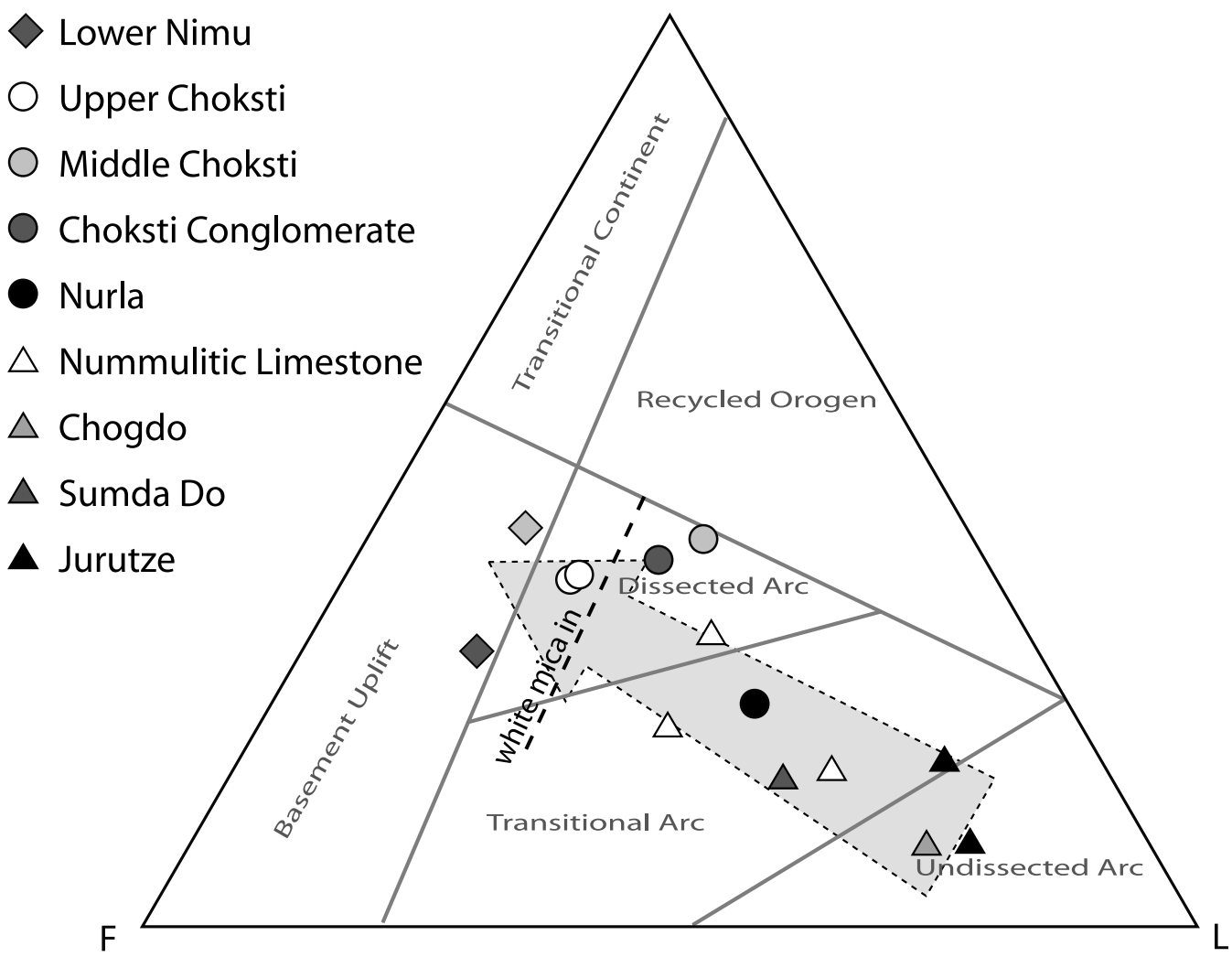

Figure 10. Ternary diagram showing the varying proportions of quartz $(\mathrm{Q})$, feldspars $(\mathrm{F})$, and lithics $(\mathrm{L})$ in Indus Basin medium-grained sandstones based on point counting results. Provenance fields are determined from Dickinson and Suczek [1979] and Garzanti and van Haver [1988]. Volcanic lithics make up the dominant lithic components. Each point represents one sample. The large arrow depicts the trend toward gradual progressive arc dissection with increasing stratigraphic height through time, as documented in these sediments by previous work of Garzanti and van Haver [1988, Figure 8] and confirmed by our new data. Approximate relative stratigraphic location for first occurrence of detrital white micas is marked.

Clift et al. [2001a, 2002a] our results show that granitoid clasts (of all types) occur abundantly throughout the stratigraphy, but become more dominant toward upper stratigraphic levels. Furthermore, converse to sandstone petrography (section 5.1), ophiolite-related clasts (peridotite, serpentinite and mélange) are notably more abundant within lower stratigraphic levels of the Nurla, Nummulitic Limestone and Chogdo formations, also in agreement with Clift et al. [2002a].

[31] Local variations in clast type and abundance do occur which are not always documented in the clast counts. In particular the Chogdo Formation is seen to contain gabbro (Figure 7c) and the Nurla Formation contains an abundance of red volcanic clasts toward the upper stratigraphic limits, whereas the quantity of chert clast abundance varies enormously throughout the stratigraphy. Carbonate clasts occurring in the Tar Group formations (Chogdo and Nummulitic Limestone) are typically black and of a similar lithology to carbonates within the Sumda and Nummulitic Limestone formations, and so an autoclastic nature of these clasts is a possibility. Light gray, muddy carbonate clasts found at higher stratigraphic levels in the Lower Nimu Formation appear unlike any carbonates observed in the IBSR units and are more likely to represent the first nonautogenic limestone clasts within the stratigraphy.

\subsection{Mudstone Geochemistry}

[32] X-ray fluorescence (XRF) analysis was conducted on five Indus Basin mudstone samples to determine the varying concentrations of trace element contribution from ultramafic/ophiolitic sources throughout the stratigraphy. Sample preparation and XRF analytical procedures closely followed those outlined by Ramsey et al. [1995] and Watson [1996], and full XRF results are available in Data Set S3. Trace element results are presented in Figure 12, normalized to the trace element concentrations of Post Archean Australian Shale (PAAS), compiled by Taylor and McLennan [1985].

[33] Analysis of an ophiolitic mélange mudstone (ZG07022; collected from $\sim 7 \mathrm{~km}$ south of our study area, close to the village of Chilling) contained significant enrichment of trace elements $\mathrm{Ni}, \mathrm{Cr}$, and $\mathrm{Co}$, and depletion of $\mathrm{V}$ and $\mathrm{Cu}$, relative 


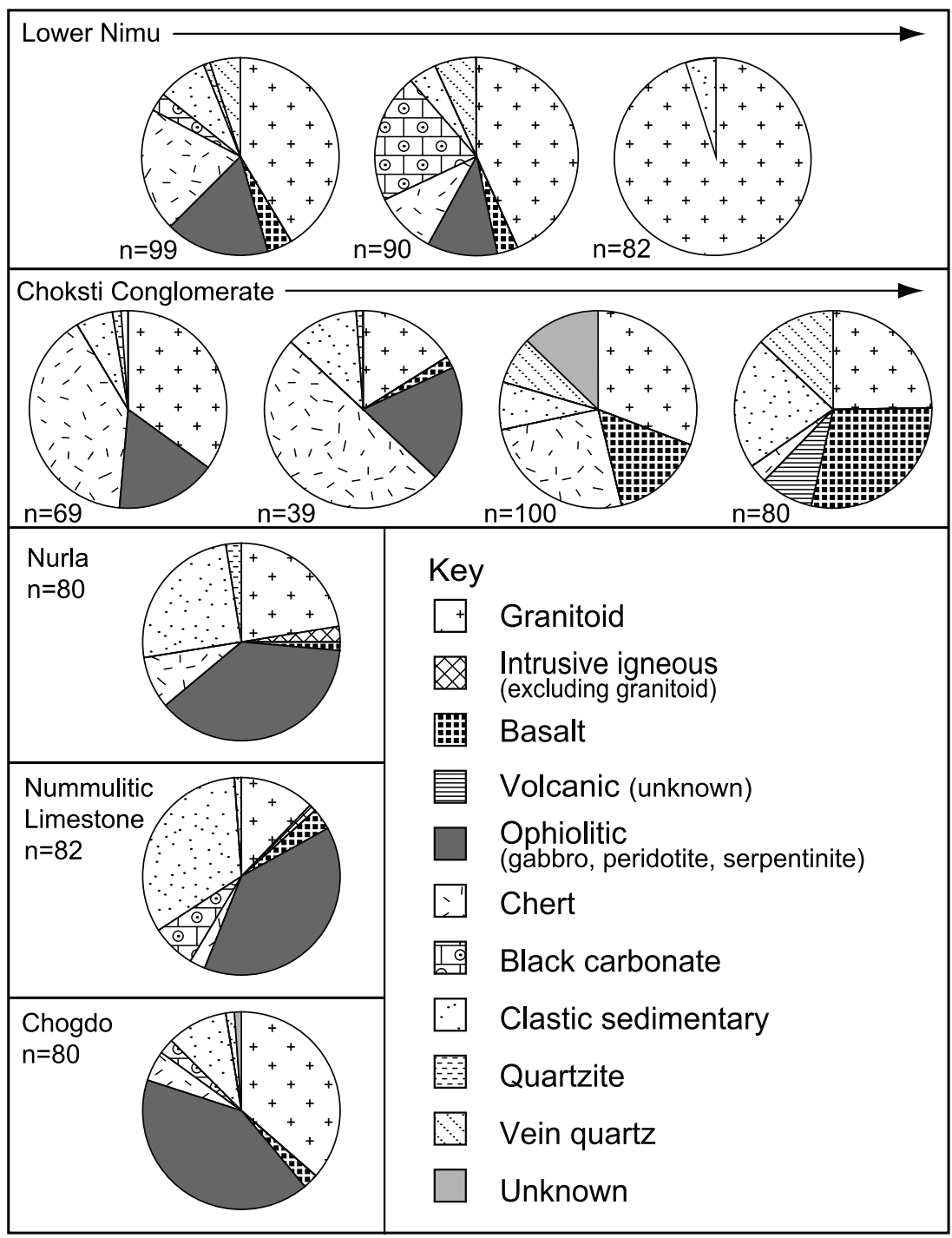

Figure 11. Pie charts displaying the changing proportions of conglomerate clast compositions as observed throughout the IBSR. Black arrows associated with the Choksti Conglomerate and Lower Nimu formations indicate relative younging direction among the samples.

to PAAS (Figure 12). Thus, we consider only $\mathrm{Cr}$, Ni, and $\mathrm{Co}$ concentrations as providing a robust means of quantifying the ophiolitic input into the IBSR.

[34] At the base of the stratigraphy, the Jurutze Formation contains relatively low, depleted $\mathrm{Cr}$ and $\mathrm{Ni}$ values which continue to decrease through the stratigraphic succession up into the Chogdo. A gradual increase to $\mathrm{Ni}$ and $\mathrm{Cr}$ concentrations is observed above the Chogdo Formation and throughout the Indus Group, in agreement with the results of Garzanti and van Haver [1988] who interpreted this enrichment in the postcollisional units as indicating an uplift of ophiolitic-ultramafic rocks immediately after the early Eocene. The Choksti Formation's Middle Sandstone Member (sample ZG06035) is the only sample to display $\mathrm{Cr}$ and $\mathrm{Ni}$ enrichment relative to PAAS. Relative concentrations of Co (compared to concentrations of PAAS) are depleted for the lower stratigraphic Formations, except for sample ZG06053 of the Chogdo Formation which, alongside the Middle Sandstone Member sample (ZG06035) both show a slight relative enrichment compared to PAAS.

\section{Isotopic Dating of Detrital Minerals}

\subsection{Uranium-206/Lead-238 Dating of Detrital Zircons}

\subsubsection{Methodology}

[35] U-Pb isotopic age dating of detrital zircons from six Indus Basin samples and two modern river sediment samples (one draining the Ladakh Batholith and the other draining Lhasa Block) was conducted at the Natural Environment Research Council Isotope Geoscience Laboratories (NIGL) at the British Geological Survey, using Laser AblationMultiCollector-Inductively Coupled Plasma Mass Spectrometry (LA-MC-ICPMS). Sample preparation closely followed Horstwood et al. [2003] and that outlined by Najman et al. 


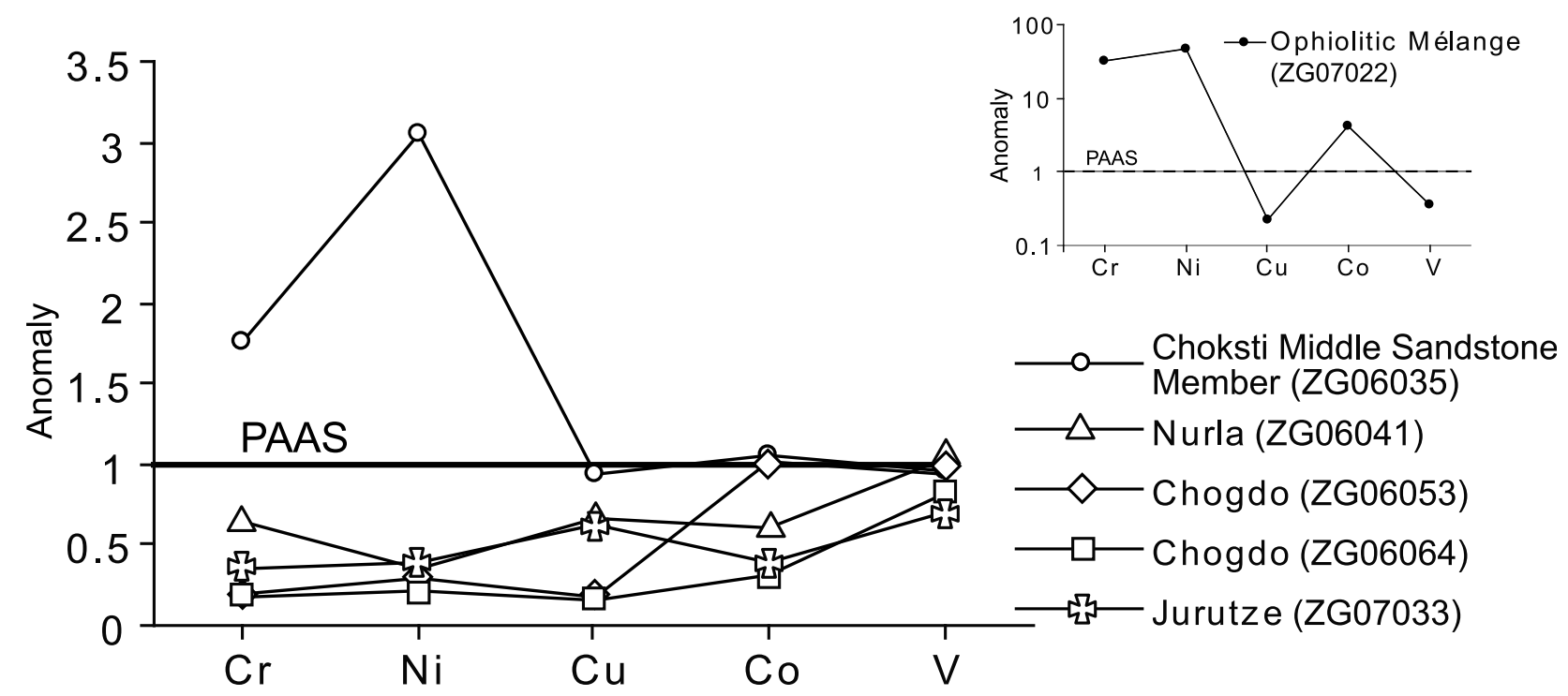

Figure 12. XRF results showing selected trace element concentrations of five Indus Basin sedimentary shales. Concentrations are normalized to trace element concentrations of Post Archean Australian Shale (PAAS) compiled by Taylor and McLennan [1985], where (in ppm) $\mathrm{Cr}=110, \mathrm{Ni}=55, \mathrm{Cu}=50, \mathrm{Co}=23$, and $\mathrm{V}=150$. Inset shows sample ZG07022, an ophiolitic mélange mudstone collected near the village of Chilling in the Zanskar Gorge, clearly depicting major enrichment (relative to PAAS) in trace elements $\mathrm{Cr}, \mathrm{Ni}$, and $\mathrm{Co}$.

[2008]. Age errors quoted are $2 \sigma$. Detail concerning the analytical procedure used is available in Text S1, with full sample and standard results in Data Set S4 and Figure S1.

\subsubsection{U-Pb Results}

[36] Histograms displaying the ${ }^{206} \mathrm{~Pb} /{ }^{238} \mathrm{U}$ ages of Indus Basin samples compared to zircon age characteristics of both Indian and Eurasian plate sources are displayed in Figure 13. Mid Cretaceous to early Cenozoic aged detrital zircons comprise the dominant age range in the Tar Group (Jurutze and Chogdo Formations), ranging from $\sim 50$ to $100 \mathrm{Ma}$. The youngest zircon analyzed within the Jurutze provided an age of $53.4( \pm 1.4)$ Ma defining a maximum age constraint to the early phases of IBSR sedimentation; younger than the $60 \pm 1$ Ma age obtained by Wu et al. [2007]. This younger date is consistent with our re-evaluation of biostratigraphic age constraints for the Sumda Formation (54.9-51 Ma; see section 4). The youngest grain identified from the upper Chogdo Formation generated an age of $50.8 \pm$ 1.0 Ma, in agreement with the biostratigraphic ages obtained from both the overlying Nummulitic Limestone (50.849.4 Ma; see section 4) and underlying Sumda Formation. A total of eight Precambrian aged zircons were found within the Jurutze, Chogdo and overlying Nummulitic Limestone formations ranging between $1118 \pm 29 \mathrm{Ma}$ and $2581 \pm 82 \mathrm{Ma}$ but above this horizon, Precambrian grains are absent.

[37] A shift in zircon age population is observed in the Nummulitic Limestone (ZG06062) compared to the Tar Group, with the two dominant age groups occurring at 85-110 Ma and 150-160 Ma, and with only three early Cenozoic-late Cretaceous aged zircons outlying these age ranges, the youngest of which was $52.5( \pm 0.7)$ Ma. The overlying Indus Group samples are all dominated by mid-Cretaceous to mid-Eocene ages, with the exception of two mid Jurassic aged grains of $171.0 \pm 4.5,173.3 \pm 3.8 \mathrm{Ma}$ occurring in the Nurla Formation (ZG06042). The youngest zircon analyzed from the Upper Nimu (ZG06016) gave an age of 41.3 Ma $\pm 1.0 \mathrm{Ma}$, providing a maximum age constraint to the deposition of the Upper Indus Group, complementary to the work of Wu et al. [2007], who obtained a youngest age grain of $41 \pm 0.3 \mathrm{Ma}$.

\subsection{Argon-40-Argon-39 Dating of White Micas \\ 6.2.1. Methodology}

[38] Four medium-grained white mica-bearing sandstone samples from the Upper and Lower Nimu Formation were

Figure 13. Histograms showing detrital zircon ${ }^{206} \mathrm{~Pb} /{ }^{238} \mathrm{U}$ ages from six Indus Basin sedimentary rock samples in ascending stratigraphic order. Here "n" refers to the number of individual zircons analyzed per sample. Insets show detailed spread of Cenozoic to Jurassic ages. The bottom chart shows probability density plots of zircon ${ }^{206} \mathrm{~Pb} /{ }^{238} \mathrm{U}$ ages characteristic of grains from the Indian Plate TSS and the Eurasian Plate. Indian Plate TSS data is from Gehrels et al. [2003], where n =948. Eurasian plate data is compiled from Chu et al. [2006], Harrison et al. [2000], Leier et al. [2007], Miller et al. [2000], Murphy et al. [1997], Schärer et al. [1984b], Wen et al. [2008], Xu et al. [1985], and modern river samples HKT10a and KL06003 analyzed as part of this project (see auxiliary material), where total $n=1323$. Errors on all data are given at $2 \sigma$

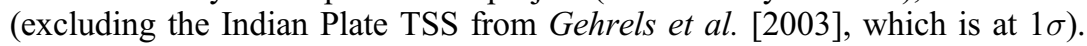




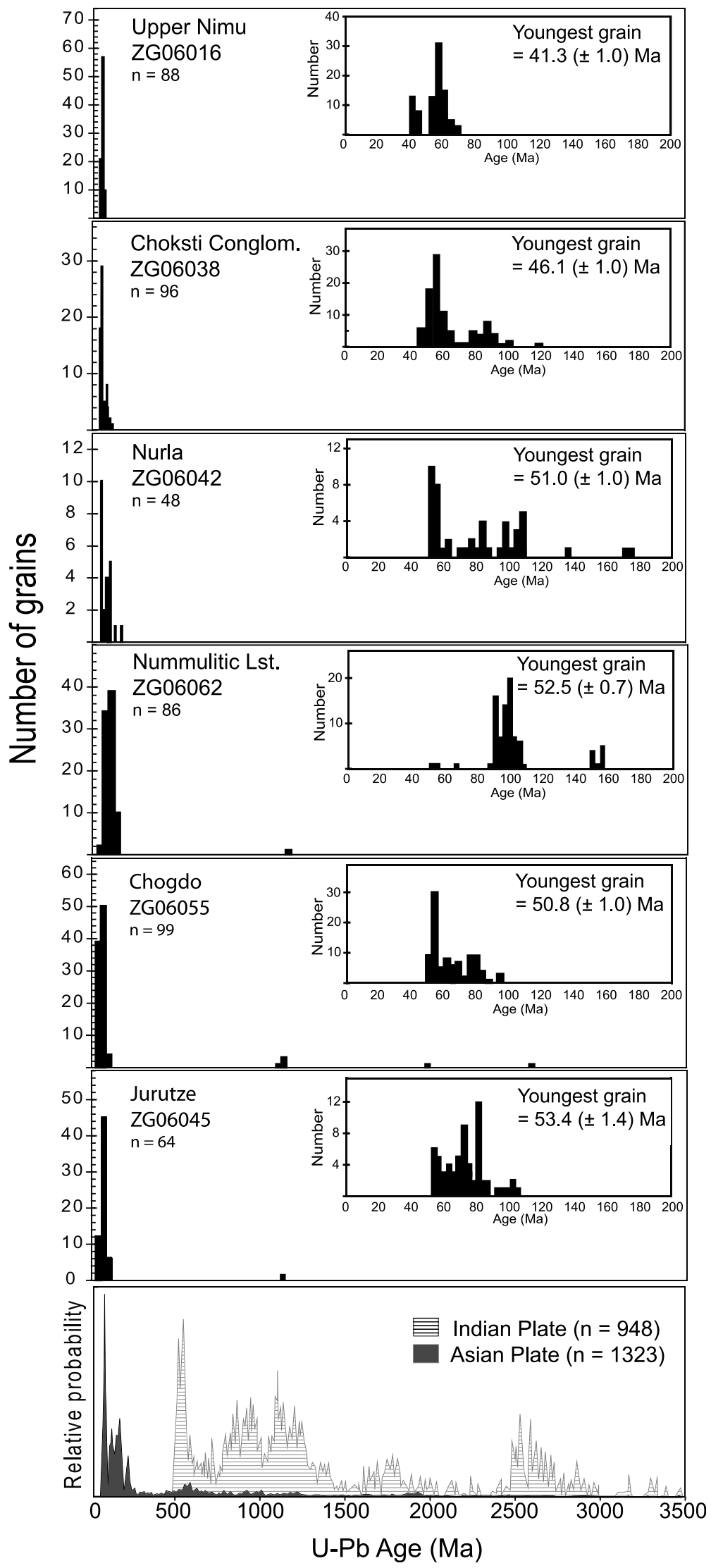

Figure 13 
selected for ${ }^{40} \mathrm{Ar}-{ }^{39} \mathrm{Ar}$ geochronology. Older formations were unmicaceous or, in the case of the Choksti Formation, present, but with a grain size too small for analysis. In addition, white micas from three modern river sand samples, draining the Indian and Asian plates were analyzed in order to improve source region characterization. The samples were crushed to gravel and sand sized grains using standard rock crushing techniques at Lancaster University. Each sample was then sieved into $250-500 \mu \mathrm{m}$ aliquots from which the micas were hand picked. They were subsequently cleaned ultrasonically in deionized water and $5 \% \mathrm{HNO}_{3}$. Mica grains were then packed in $\mathrm{Cu}$ foil packages and stacked in quartz tubes. Interdispersed among the $\mathrm{Cu}$ packets were $\mathrm{Al}$ foil packets containing the International ${ }^{40} \mathrm{Ar}-{ }^{39} \mathrm{Ar}$ Age Standard, Fish Canyon Tuff sanidine (FCs; $28.02 \pm$ $0.16 \mathrm{Ma}, 1 \sigma$ ) [Renne et al., 1998] to permit characterization of the irradiation flux to the samples. Samples were irradiated for $12 \mathrm{~h}$ in the McMaster reactor, Ontario, Canada. Laser fusion of single mica grains was used to extract the Ar. We used a $25 \mathrm{~W}$ Merchantek $\mathrm{CO}_{2}$ laser. A 3\% power step was used to degas surface contaminants (e.g., atmospheric ${ }^{40} \mathrm{Ar}$ ) and a $15 \%$ step was used for complete fusion. The sample gas was cleaned in a fully automated all-metal extraction line by two GP50 getters (one operated at $450^{\circ} \mathrm{C}$ and the other at room temperature) and a slush trap maintained at $-140^{\circ} \mathrm{F}$ by a mixture of $\mathrm{CO}_{2(\mathrm{~s})}$ and acetone. Data were collected using an ARGUS multicollector mass spectrometer at the NERC Argon Isotope Laboratory, which is housed by the Scottish Universities Environmental Research Centre, Scotland [Mark et al., 2009]. For off-line data reduction, we used an in-house Excel-based method of age calculation (constructed by $\mathrm{D}$. Barford). ${ }^{40} \mathrm{Ar}-{ }^{39} \mathrm{Ar}$ age results are presented as probability density plots in Figure 14, and full analytical results are provided in Data Set S5. Detrital micas from the Lower Nimu Formation were particularly small and sparse in abundance; thus only a relatively low number of micas were analyzed. Measurement quality deteriorated, and uncertainties rapidly rose when the sample to blank ratios of ${ }^{40} \mathrm{Ar}$ were lower than ca. 10 , and as a result only analyses with a higher sample/blank ratio are used. This particularly affects the ability to measure small and young grains.

\subsubsection{Argon-40-Argon-39 Results}

[39] Modern river sand samples HKT10a and HKT11a draining the Eurasian Plate contain white micas with Early Cretaceous to Early Jurassic ages as well as Mid-, but predominantly Late Miocene aged grains, whereas sample Zansk-02 collected from a modern river sand draining the Indian Plate contains white micas with Late Eocene to Late Miocene ages.

[40] Considering the samples from the IBSR sandstones, previous illite crystallinity studies on the Indus Group determined that postdepositional burial temperature did not exceed lower anchizone metamorphic conditions of c. $200^{\circ} \mathrm{C}$ [Clift et al., 2002a], implying that the detrital white micas have remained well below the white mica closure temperature of ca. $350^{\circ} \mathrm{C}$ [Jäger, 1967; McDougall and Harrison, 1999; von Blanckenburg et al., 1989] throughout postdepositional times. Therefore on this basis we make the assumption the analyzed ages represent the timing of cooling in their original source terrane.
[41] The Lower Nimu samples yield dominantly mid Eocene to lower Oligocene white mica ${ }^{40} \mathrm{Ar}-{ }^{39} \mathrm{Ar}$ ages. Samples NIMU-09 and ZG07042 from the Upper Nimu contain the youngest analyzed grains, yielding Late Miocene ages, however we do note that the age errors on some of the younger grains are exceptionally high due to their low radiogenic yields. Nevertheless, the maximum age of deposition for this formation can be assigned to Upper Miocene times, in agreement with comparable work done using zircon fission track analyses [Schlup et al., 2003]. This is considerably younger than the youngest $\mathrm{U}-\mathrm{Pb}$ detrital zircon age of $41.3 \pm 1.0 \mathrm{Ma}$.

\section{Paleoenvironmental Reconstruction and Interpretation}

\subsection{Tar Group Sedimentation}

[42] The initial phases of Indus Basin sedimentation represented by the shales of the Jurutze Formation began with marine deposition in the forearc of the Transhimalayan arc (in agreement with Clift et al. [2002a], Garzanti and van Haver [1988], and van Haver [1984]). The increasing occurrence of more proximal sedimentation with time, ultimately leading to the deposition of the Sumda Formation indicates a switch from deeper marine sedimentation of the Jurutze to shallower marine environments of the Sumda Formation.

[43] The increase in sandstone upsection with a conformable transition into the subaerial oxygenated environment of the Chogdo Formation (marked by the presence of red shales) combined with coarse, well-rounded clastic material and erosive based sandstones suggests that deposition evolved to a near coastal transitional environment such as a continental alluvial to subaqueous delta plain setting. A delta system would likely have prograded out into shallow marine conditions, feeding the Neo-Tethyan marine margin with arc-derived sediment. The overall fining upward pattern observed within the Chogdo corresponds with a return to shallow marine environments marked with the occurrence of the Nummulitic Limestone.

\subsection{Indus Group Sedimentation}

[44] Facies characteristics of the Nurla Formation are very similar to those of the Chogdo Formation, suggesting that sediment was again deposited on a delta-plain marking an overall shallowing up cycle from the marine Sumda Formation. Due to the tectonic contact, the relationship between deposition of the Nurla Formation and sedimentation of the overlying Choksti Conglomerate is not certain, but is assumed to be relatively continuous in time. The general coarse nature of facies belonging to the Choksti Conglomerate clearly suggests that deposition occurred in a very high-energy proximal environment such as an alluvial fan or gravel-dominated braided river. However, the deformed nature of the succession and the lack of paleocurrent data, both in this formation and throughout the succession, preclude an assessment of the degree of downslope decrease in grain size, and radial paleodrainage pattern, which are required to differentiate between these 


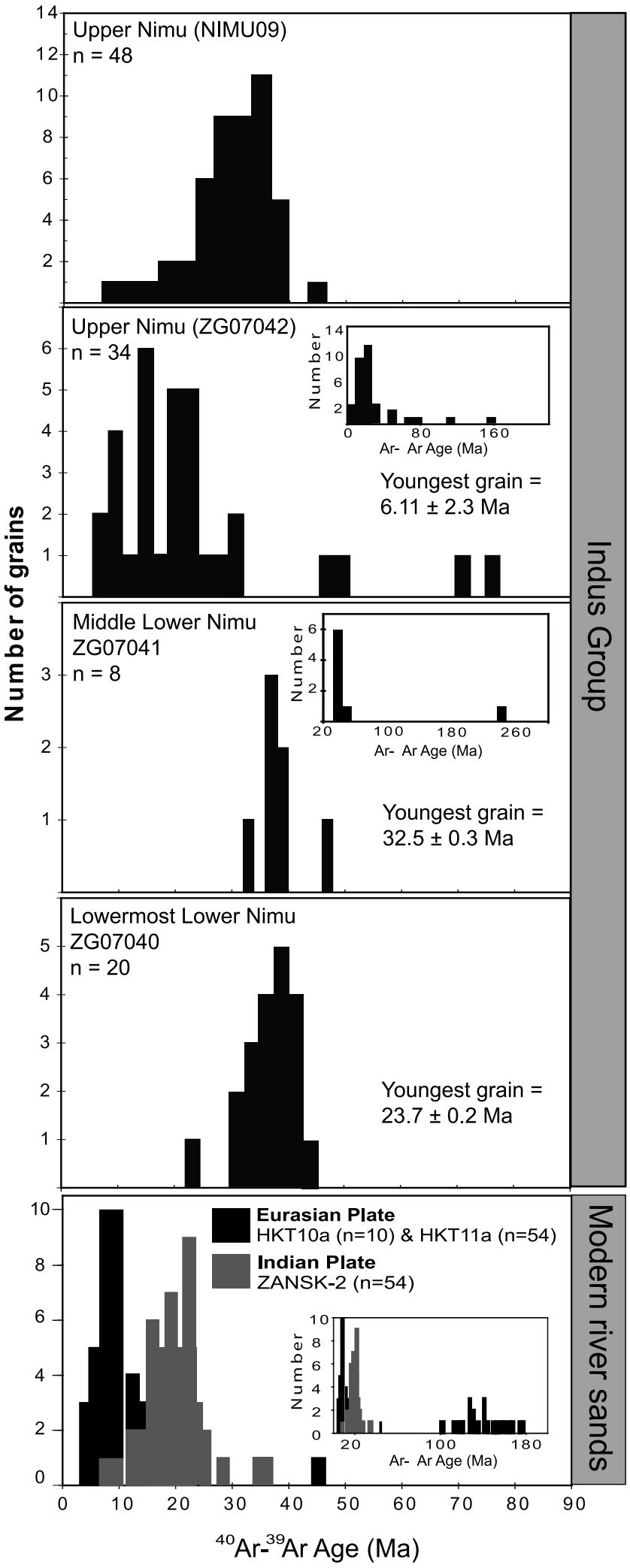

Figure 14. Histograms displaying ${ }^{40} \mathrm{Ar}-{ }^{39} \mathrm{Ar}$ ages of detrital white micas from four Indus Group samples and three modern river sand samples (stacked histogram). Here " $n$ " refers to the number of mica grains analyzed per sample. two paleoenvironmental settings. To some extent, such a distinction is blurred in any case, since transport and deposition of material on alluvial fans often occurs by braided rivers.

[45] The Red Shale Member of the Choksti Formation represents deposition in an oxidizing, low-energy environment likely on a distal part of an alluvial fan or in the floodplain adjacent to a river. A gradual transition to more established fluvial environments is then observed first with the presence of cross bedded sandstone point bar deposits and well-interbedded overbank shales and sandstones occurring at the base of the Middle Sandstone Member (Figure 5g), representative of sheet flooding. This evolves into established fining upward sedimentary cycles characterized by the presence of gravel and sandstone in illdefined channels, infrequent conglomerate and absence of extensive overbanks, within the Choksti Formation's Middle and Upper Sandstone Members indicating deposition in a higher-energy alluvial environment. The occurrence of symmetrical ripples in these members indicates periods of oscillatory flow; an atypical feature within fluvial environments. These wave formed symmetrical ripples could indicate deposition when the alluvial channel system periodically entered a wave dominated shoreline, for example, that of an intermontane basin lake as suggested by Sinclair and Jaffey [2001].

[46] Lower Nimu sedimentation is marked by a noticeable change in depositional setting with the occurrence of large lenticular beds indicative of a major channelized, river system (Figure 71). The relatively low occurrence of shale beds combined with the presence of shale rip up clasts within angular coarse-grained sandstone and conglomerates suggest that deposition occurred in a high- to moderateenergy fluvial environment where channelized sands eroded and obliterated preexisting floodplain shales and overbank deposits. We propose that the Upper Nimu represents a continuation to deposition within this major channelized river system, however it is rather more representative of floodplain overbank and crevasse splay deposits with associated back swamps. The general coarsening up nature of the both the Lower and Upper Nimu formations records the history of a laterally prograding river over its associated channel margin, levee-floodplain deposits.

\section{Provenance}

[47] The establishment of the IBSR provenance is important for both paleogeographic reconstruction and also for constraining the timing of India-Eurasia collision as determined by the first mixing of Indian- and Eurasianderived detritus within the ITSZ and/or first arrival of Eurasian detritus onto the Indian plate.

\subsection{Previous Work}

[48] The Chogdo Formation is interpreted by Clift et al. [2001a, 2002a] as representing the oldest ITSZ unit that shows evidence of a mixed India and Eurasian provenance. Clift et al. [2001a, 2002a] interpret the granitoid conglomerate clasts as derived from the Eurasian margin (Transhimalayan/Ladakh arc), whereas clasts of red chert, 
basalt, peridotite and associated ophiolitic material are all interpreted as derived from the Spontang ophiolite proposed as obducted onto the Indian plate either by this time [Corfield and Searle, 2000; Searle et al., 1997a] or in post-early Eocene times [Garzanti et al., 1987]. However, the lack of preserved south directed paleocurrents was highlighted by Clift et al. [2001a] as a potential problem with regards to explaining the presence of these granitoid clasts as there are no known granitic sources of similar affinities which lie to the south.

[49] More recent studies using detrital zircon U-Pb dating and Hf isotopic analysis by $W u$ et al. [2007] found Cretaceous Transhimalayan-derived grains to dominate the IBSR detrital zircon population, and the authors interpreted the presence of Precambrian aged grains within the Tar Group as representative of a Lhasa Block rather than Indian plate origin. Wu et al. [2007] found the possibility for the first mixed Indian and Eurasian plate contribution only in the uppermost stratigraphic levels of the Indus Group (equivalent to our defined Nimu formations). Their evidence was based on the presence of two detrital zircons analyzed to yield ages interpreted by them as unique to the Indian Plate; one with a Hf model age of $3.4 \mathrm{Ga}$ and the other with a $\mathrm{U}-\mathrm{Pb}$ age of $278 \pm 2 \mathrm{Ma}$.

[50] Bulk rock Nd isotopic studies are in agreement with the interpretation of a dominantly Eurasian source. $\varepsilon_{\mathrm{Nd}}$ values throughout the IBSR are relatively high, indicative of a dominant Transhimalayan source, with an overall shift to more negative $\varepsilon_{\mathrm{Nd}}$ values toward higher stratigraphic levels [Clift et al., 2001a]. This change was suggested to be a result of an additional input from the Lhasa Block by Clift et al. [2001a], based on their documented west directed paleocurrents preserved within the IBSR (Figure 6), rather than a possible contribution from the northerly located Karakoram. Furthermore, the possibility of an Indian Plate input to explain the shift was also considered unlikely by Clift et al. [2001a] as they considered there to be a lack of any detrital $\mathrm{K}-\mathrm{Spar} \mathrm{Pb}$ isotope data, or muscovite and garnet, reflective of a typical Indian Plate source, within the IBSR at this level. However, subsequent additional Indian Plate K-spar $\mathrm{Pb}$ isotope characterization [Clift et al., 2002b] shows similar affinities to a small proportion of detrital K-spars analyzed from the IBSR, and one would not expect metamorphic mineralogies to be eroded from High Himalayan "cover" during early stages of its exhumation [Najman and Garzanti, 2000].

[51] In support of the proposed lack of Indian plate input, $\mathrm{Sm}-\mathrm{Nd}$ isotopic data on individual detrital apatite grains from the IBSR [Henderson et al., 2010] showed no conclusive evidence of an Indian Plate input; detrital apatites are dominantly Transhimalayan derived, with possible detrital apatite input from the Lhasa Block at higher stratigraphic levels. Despite this evidence, the initial interpretations by Clift et al. [2001a] remain in conflict with north directed paleocurrents [e.g., Sinclair and Jaffey, 2001] (see Figure 6).

[52] In summary, previous work is contradictory and inconclusive in its determination of provenance and thus the use of these rocks to constrain the timing of India-Asia collision based on earliest recorded mixing of Indian and Asian detritus is not clear-cut.

\subsection{Provenance Interpretations}

[53] The dominance of Cretaceous-Cenozoic aged zircons obtained from our detrital zircon data study of the IBSR clearly suggests sediment derivation from the Eurasian Plate Transhimalaya since zircons of such age are extremely limited or absent in the Tethyan and Higher Himalaya of the Indian plate (Figure 13). Subordinate older (Precambrian) grains could be either Indian or Eurasian (Lhasa Block) (e.g., Chu et al. [2006], Leier et al. [2007], and Figure 13) derived. Wu et al. [2007] considered it more likely that the subordinate Precambrian zircons identified from the Tar Group were sourced from the Lhasa Block basement based on their interpretation of zircon $\mathrm{Hf}$ data. Jurassic $\mathrm{U}-\mathrm{Pb}$ detrital zircon ages obtained from Nummulitic Limestone (ZG07062) and Nurla (ZG06042) samples (see Figure 13) are likely to have either been sourced from north Kohistan [Schaltegger et al., 2002], Lhasa Block (see HKT10A/11A in Figure 14), and/or gabbros and ultramafics associated with the Dras Arc complex [Reuber et al., 1989]. We conclude that zircon $\mathrm{U}-\mathrm{Pb}$ ages provide no unequivocal evidence for an Indian Plate contribution to the IBSR.

[54] A predominantly Eurasian source for the IBSR is backed up by petrography. Evolution of the sandstone petrography (Figure 10) indicates that the IBSR were dominantly derived from a magmatic arc which was undergoing progressive dissection and unroofing of volcanic cover to granitoid roots (as defined by Dickinson and Suczek [1979] and modeled by Garzanti et al. [2007]) in agreement with the work of Garzanti and van Haver [1988]. This progressive dissection is additionally recorded by the upsection increase (by the time of deposition of the Upper Nimu Formation) in proportion of granitoid clasts in the conglomerates and increase in detrital quartz, plagioclase, and hornblende, and subsequent decrease in volcanic lithic grains in the sandstones.

[55] Our conclusions differ from some previous investigations which advocate input from the Indian plate early in the stratigraphy, based on petrography, presence of north directed paleocurrent indicators and sedimentary and ophiolite conglomerate clasts (interpreted as derived from Indian passive margin and the Spongtang ophiolite obducted onto the Indian plate, respectively). Brookfield and AndrewsSpeed [1984] suggested that IBSR petrography indicated a continental block or recycled orogen source for Indus Basin sediments. We suggest that these provenance conclusions may have arisen from previous workers' overestimation of sedimentary lithic clasts and/or matrix content [Garzanti and van Haver, 1988], or underestimation of feldspars, many of which have been heavily (partially) altered to clays.

[56] The overall scarcity of preserved paleoflow indicators within the Tar Group, combined with the two episodes of contraction deformation (see section 3) means that paleocurrent measurements from these lower stratigraphic levels are likely to be both inaccurate and imprecise. The variability in paleoflow data is clearly documented within measurements from the Chogdo Formation with tectonically restored paleoflow recordings from this study showing a southwest flow component, opposing the observed north-northeast 
flow direction obtained by Clift et al. [2001a] from the same stratigraphic level.

[57] We consider that the observed clastic and carbonate sedimentary clasts identified within the Tar Group are likely to be autoclastic in nature (see section 5.2). We suggest that ophiolitic and chert clasts, interpreted by previous workers as derived from the Indian plate, could be Eurasian derived. The occurrence of ophiolite detritus was suggested by Garzanti and van Haver [1988] to have been supplied from the northern Shyok Suture Zone (SSZ). Due to its considerably northerly location and the likely high topography existing between the SSZ and ITSZ by that time, we suggest that this is unlikely, though possible based on the occurrence of Precambrian zircons in the IBSR, most likely derived from Eurasian plate basement lying to the north of the arc [Wu et al., 2007]. More likely, a probable Eurasian source for these clasts can be found in lithologies associated with the Dras Arc [Searle et al., 1999]. The rather limited present-day exposure of oceanic rocks preserved in the Dras Arc unit on the Eurasian margin [Reuber, 1989] contains ultramafics (peridotites), gabbro and diabase in association with a Jurassic aged chert assemblage [Honegger et al., 1982; Reuber, 1989]. Thus, we suggest that it is viable for the Tar Group to contain solely Eurasian plate-derived clasts and detritus.

[58] The lowest stratigraphic level within the IBSR to show unequivocal evidence of a mixed India and Eurasian input is the Upper Sandstone Member of the Choksti Formation, marked by the first occurrence of detrital white micas (see section 5.1). White micas increase in abundance upsection and become datable (due to their increased grain size) in the overlying Nimu Formation. Mid Eocene to Upper Miocene mica $\mathrm{Ar}-\mathrm{Ar}$ ages are consistent with sourcing from the Indian Plate's HHCS which was exhuming at that time and from which white micas of such age have been recorded [Brewer et al., 2006; Szulc et al., 2006; White et al., 2002] (Figure 14). White mica is rare from Transhimalayan mineral assemblages, and Lhasa Block sourced white mica ages, predominantly of Late Miocene and Early Cretaceous age (our samples HKT10a and HKT11a) are not comparable with the majority of our analyzed Indus Group detrital ages. No other High Himalayan associated metamorphic assemblages, such as medium-grade metamorphic rock fragments, or other Barrovian metamorphic minerals were identified. This is to be expected during the early stages of exhumation of the HHCS, when the less metamorphosed shallower cover was being eroded. Therefore, we also recognize that less metamorphosed nonmicaceous Indian plate material likely was exhumed earlier than the detrital micas seen in the Upper Sandstone Member of the Choksti Formation and may lie undetected in older IBSR.

[59] Within the Lower Nimu Formation is also the presence of what we interpret to be nonautogenic limestone clasts; our argument regarding their nonautogenic nature based on the lack of limestone formations preserved in the upper stratigraphic levels of the IBSR, and the dissimilarity of the clast carbonate lithology compared to limestones found in the IBSR (see section 5.2). We propose that the limestone clasts were sourced from the Indian Slope margin, as the Eurasian plate limestones (e.g., Sumda, Num- mulitic, and Khalsi limestones) were likely to be buried by this time.

[60] Therefore our provenance data show that the IBSR are overwhelmingly dominated by Eurasian sources, with only the first unequivocal suggestion of an additional Indian Plate sedimentary input in the Lower Miocene Choksti Formation's Upper Sandstone Member, with the appearance of (undated) white mica followed by dated white micas and limestone clasts interpreted as Indian plate origin in the overlying Nimu Formation. These data are in agreement with our previous work using a new technique, $\mathrm{Sm}-\mathrm{Nd}$ analyses on single grain apatites, to discriminate between Indian and Eurasian sources in the IBSR [Henderson et al., 2010], and similar to observations in the Yarlung Tsangpo suture zone (the easterly equivalent of the ITSZ) where in Tibet the Lower Miocene Gangrinboche conglomerate is the first formation to record evidence of mixed Indian and Eurasian plate input [Aitchison et al., 2002].

[61] We conclude that in this studied section (the Zanskar Gorge), the Chogdo Formation does not contain evidence of mixed Indian-Asian detritus, and does not constrain India-Asia collision to have occurred by $50 \mathrm{Ma}$. Henderson et al. (submitted manuscript, 2010) expand on this topic, discussing both the evidence for first arrival of Asian material on the Indian plate, as well as first documentation of mixed Indian and Asian detritus in the IBSR, also encompassing a wider geographical study area where the IBSR is exposed.

\section{Paleo-Indus River Initiation}

[62] The modern-day Indus River (Figure 1) represents a major axial river system within the Himalaya. Initiating at Mount Kailas in south Tibet and flowing west along the ITSZ before diverting southward to cut through the Indian plate, the Indus is responsible for transporting vast quantities of sediment eroded from the central and western Himalaya toward the river's terminus at the Indus Fan in the Arabian Sea. Thus, the need for determining the timing of Indus River initiation during the early phases of orogenesis is vital if we are to understand the rate of sediment denudation, and assess mechanisms of coupled tectonics and exhumationerosion processes [e.g., Zeitler et al., 2001].

[63] Whole rock $\mathrm{Nd}$ and $\mathrm{K}$-feldspar $\mathrm{Pb}$ isotopic analysis on mid Eocene Indus Fan sediments has indicated that sediment was likely sourced from a mixture of the Eurasian crust (Lhasa and Karakoram blocks), Kohistan-Ladakh Island Arc/Transhimalaya, and Indian plate, implying that a major river drained as far north as Eurasia and deposited material into the Indus Fan just after India-Eurasia collision [Clift et al., 2001b]. However, the precise source of these Paleogene fan sediments remains difficult to interpret, and the date of paleo-Indus River initiation as an axial river flowing along the suture zone, remains controversial [Clift et al., 2001a; Najman, 2006, section 5.2.2.2; Searle et al., 1990; Sinclair and Jaffey, 2001].

[64] In the Zanskar Gorge section, westerly directed paleoflow indicators in the Nurla and Choksti Formations [Clift et al., 2001a, Figure 6] were interpreted by those authors to suggest initiation of an axial flowing paleo-Indus 
River within the ITSZ as early as mid-Eocene times. Clift et al. [2001a] supported their view by arguing that the shift in $\varepsilon_{\mathrm{Nd}}$ values between their Chogdo and Nurla formations (as discussed in section 8) could only be explained by input from the Lhasa Block which lies to the east of the study area, thus confirming axial drainage. However, Sinclair and Jaffey [2001] concluded that the Indus Group exposed along the Zanskar Gorge does not record evidence for axial paleo-Indus River initiation, based on variable paleoflow directions throughout the stratigraphy which they interpreted as the result of transverse drainages into an internally drained basin. Furthermore, contrary to Clift et al. [2001a, 2002a], Najman [2006] did not consider that a Lhasa Block input was necessary to explain the shift in $\varepsilon_{\mathrm{Nd}}$ to more negative values between deposition of the Chogdo and Nurla formations. Rather she suggested that the shift could be explained by greater contribution from the Karakoram, considered to be an along-strike equivalent of the Lhasa Block which lies due north of the Zanskar Gorge study area, with the detritus delivered by transverse drainages.

[65] Combining our paleodepositional environmental and provenance interpretations (see sections 7 and 8) with our own paleoflow data (Figure 6) we assess the significance that our data bears for providing evidence concerning the initiation of the paleo-Indus River.

[66] Symmetrical ripples preserved in the shallow marine Sumda Formation provide a northeast-southwest paleoflow direction, perpendicular to the Eurasian continental paleomargin. We find very few reliable paleoflow indicators preserved within the Chogdo Formation, and those that there are suggest flow to the southwest. There is no evidence of mixed Indian- and Eurasian-derived detritus in the formation (see section 8) which could support an interpretation of transportation in an axial river environment. Asymmetric shallow marine ripples in the Nummulitic Limestone show a southward directed current. We recognize that the overall low abundance of available paleocurrent indicators within the Tar Group, in particular from the nonmarine facies, hinders the possibility for making robust paleodrainage interpretations for these formations.

[67] We did not record any paleocurrent data from the Nurla Formation. Contrary to Sinclair and Jaffey [2001], we discount any apparent clast imbrications within the Choksti Basal Conglomerate as being valid paleoflow indicators (as outlined in section 3.2.2). As discussed in section 7.2 it is difficult to determine the exact depositional environment of this conglomerate. Paleoflow measurements are based on trough cross bedding (representing main channel flow) and asymmetrical ripples (interpreted as relating to overbank deposition, e.g., by crevasse splay, perpendicular to main channel flow), which overall provide a southerly directed paleoflow (Figure 6) indicative of transverse drainage. This, combined with the dominant presence of proximally sourced large $(<30 \mathrm{~cm})$ gravel clasts suggests a paleodepositional environment atypical for major axial river development. Symmetrical ripples taken from the Middle and Upper Sandstone Members of the Choksti Formation record northnortheast-south-southwest wave direction perpendicular to a proposed intermontane lake shoreline (section 7.2, Figure 6) while planar cross bedding indicates a north-northeast directed flow, based on only four measurements. Provenance data potentially show first evidence of mixed Indian and Asian detritus, with the first occurrence of (undated) white mica (section 8).

[68] Evidence of an axial paleo-Indus River occurring within this examined area (i.e., the Zanskar Gorge) is recorded at the base of the Lower Nimu Formation which is marked by both a change in sedimentary environment with the development of a major more stable channel river system (section 7.2, Figure 71), and also the introduction of limestone clasts possibly sourced from the Indian margin (section 8.1), and white micas with $\mathrm{Ar}-\mathrm{Ar}$ ages typical of High Himalayan derivation (micas in the underlying Choksti Formation were too small for analysis but in all probability were derived from the same source). Paleoflow indicators formed in the channel environment (e.g., trough cross bedding and flute casts) provide a northwest paleoflow direction (Figure 6), while sedimentary structures which may be more readily produced in association with overbank deposition (e.g., asymmetrical ripples, as observed on the modern-day Indus River banks), preserve northeast directed paleoflows, perpendicular to the main river channel, as might be expected from overbank flow.

[69] In summary, we see unequivocal evidence for development of a northwest directed axial river in the (<Miocene) Nimu Formation. Since the modern-day Indus River is composed of a range of fluvial morphologies from braided and anastomosing in its upper reaches, to meandering and straight river channels further downstream [Jorgensen et al., 1993], braided facies of the Middle and Upper (white mica bearing) Choksti Formation sandstone members could represent early initiation of a throughflowing paleo-Indus (interchangeable with lacustrine environments), however there is a lack of reliable northwest directed paleocurrent data to confirm this.

[70] The paleoenvironmental and provenance interpretation outlined above therefore imply that an axial river had yet to be established within this examined Ladakh region of the ITSZ during mid-Eocene times. Contrary to the view of Clift et al. [2001a], our observations suggest that axial throughflow of the paleo-Indus within this study area began around the Early Miocene. This is consistent with the marked increase in Indus Fan sedimentation in the Middle Miocene and associated strong channel-levee development [Clift et al., 2001b]. Prior to this time, data from the Indus Fan indicate that a river draining the Indian Plate and Transhimalaya/Kohistan Ladakh island arc was sourcing the fan, but there is no evidence from this region that it flowed axially along the suture zone prior to Late Oligocene - Early Miocene times.

\section{Summary: Paleogeographic Reconstruction}

[71] The Shyok Suture Zone (SSZ), to the north of the ITSZ represents the line of collision between the KohistanLadakh Island Arc and Eurasia during mid-late Cretaceous times and further south, the ITSZ is considered to record collision between the combined Eurasian plate and the 
a) Post collision of Dras-Kohistan-Ladakh arc with Eurasia Mid Cretaceous to < 54.9-51 Ma

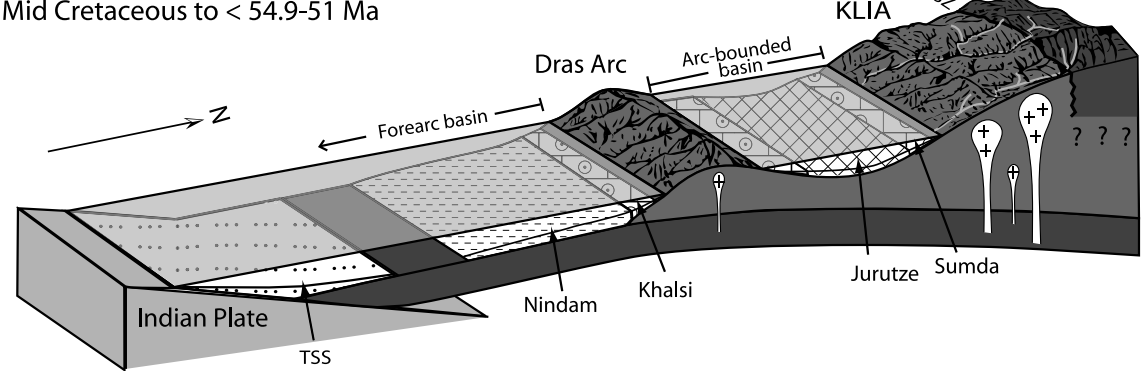

b) Continental sedimentation in an arc-bounded basin 54.9-51 Ma to 50.8-49.4 Ma

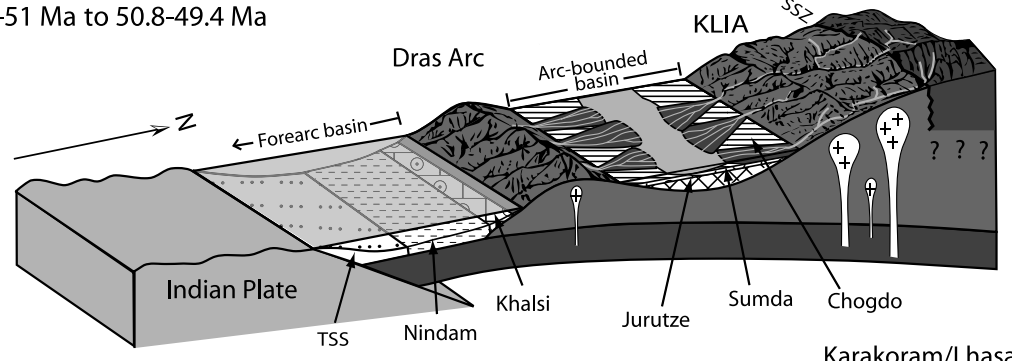

\section{c) Marine Incursion}

$50.8-49.4 \mathrm{Ma}$

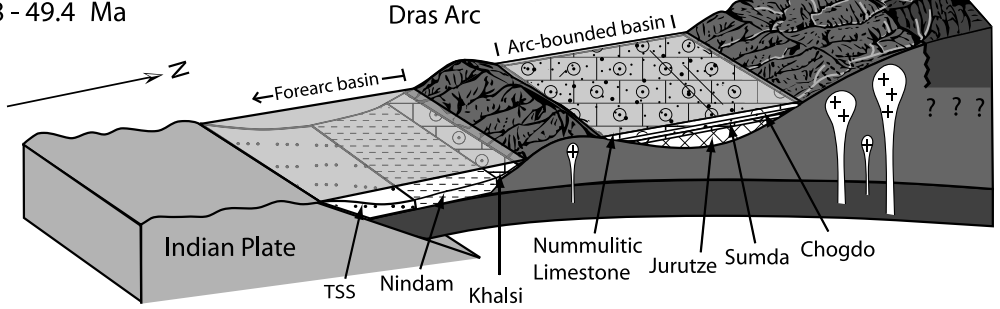

d) North-derived transverse alluvial drainage following final Tethyan retreat Post 50.8 - 49.4 Ma to C. $24 \mathrm{Ma}$

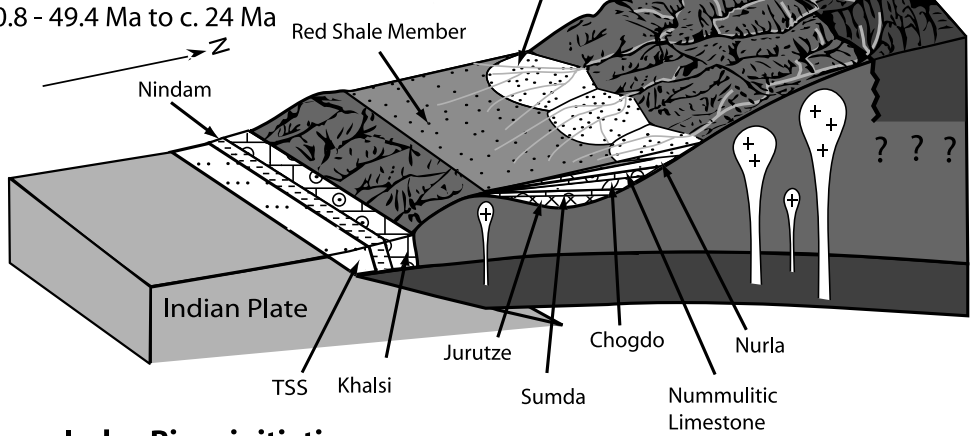

e) Palaeo-Indus River initiation

c. $24 \mathrm{Ma}$

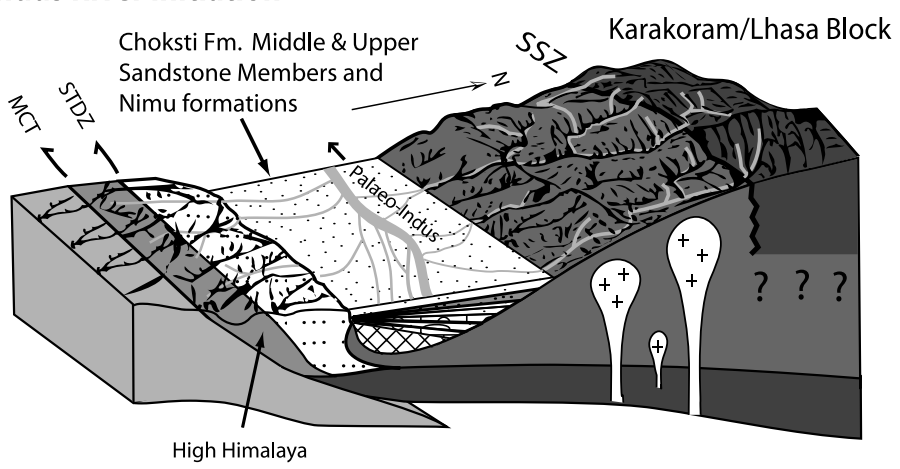

Figure 15 
Kohistan-Ladakh Island arc, with the Indian plate [Clift et al., 2001a, 2002a; Garzanti and van Haver, 1988; Najman, 2006; Searle et al., 1988; Treloar et al., 1989a]. However, much uncertainty still exists with regards to the order and nature of tectonic events which governed the early phases of India-Eurasia collision. One of these issues concerns the collisional history of Kohistan-Ladakh Island Arc with most authors suggesting that it collided with Eurasia before India in the mid-late Cretaceous [e.g., Clift et al., 2000; Gaetani et al., 1993; Maheo et al., 2006; Robertson and Collins, 2002; Rolland et al., 2000; Searle et al., 1988; Treloar, 1997; Treloar et al., 2003], and others suggesting an India-arc collision at $61 \mathrm{Ma}$, predating India-Eurasia collision at $50 \mathrm{Ma}$ [e.g., Andrews-Speed and Brookfield, 1982; Khan et al., 2009]. Although that problem is beyond the scope of this paper, detrital zircon data from the Jurutze Formation (see section 8) suggests Lhasa Block contributing sediment within the ITSZ by $53.4( \pm 1.4) \mathrm{Ma}$, favoring docking of the Kohistan-Ladakh Island Arc and Eurasia earlier than a $50 \mathrm{Ma}$ India-Eurasia collision. We recognize, however, that further analysis and terrane characterization (e.g., Hf analysis of detrital zircons to confirm the distinction between Indian and Lhasa Block characteristics for Precambrian zircons) is needed to corroborate this interpretation. For the purpose of our model we follow the more widely held theory which has Kohistan-Ladakh Island Arc-Eurasia collision prior to India-arc collision and we advance the following paleoenvironmental and tectonic model governing the deposition of the Indus Basin sediments within the ITSZ during the different phases of collision.

[72] 1. Post collision of Dras-KLIA with Eurasia occurs (Figure 15a; Jurutze and Sumda Formations, mid-Cretaceous $<54.9-51 \mathrm{Ma}$ ). During mid-Cretaceous to early Eocene times the former Kohistan-Ladakh Island arcs and Dras island arcs had docked against the southern margin of Eurasia, to form the active continental arc system above a northward dipping subduction zone consisting of Neo-Tehyan oceanic crust [e.g., Corfield et al., 2001; Mahéo et al., 2004; Rolland et al., 2002b; Thakur and Mishra, 1984; Treloar et al., 1996]. The present-day occurrence of Dras Arc volcanics and associated volcaniclastic forearc lithologies of the Nindam Formation at the southern margins of the ITSZ, south of the Indus Basin sediments [Clift et al., 2000, 2002a; Robertson and Collins, 2002; Steck, 2003] suggests that direct correlation of the Dras Arc with the Kohistan-Ladakh arc, which lies to the north of the Indus Basin sediments [e.g., Coward et al., 1986], is not straightforward. We suggest that, in accordance with the model of Garzanti and van Haver [1988], early Indus Basin sedimentation (Jurutze and Sumda Formations) took place in an arc-bounded depression between the Kohistan-Ladakh arc to the north and the Dras arc to the south. Sedimentation was dominated by the deposition of marine shales (Jurutze Formation) and associated limestones (Sumda Formation). Sediment was sourced from the Eurasian plate, predominantly derived from the KohistanLadakh Island Arc volcanics with a minor component derived from early exhumed granites. Granitoid plutons were continually intruded into the adjoined Dras/Kohistan-Ladakh arc-Eurasian margin in an Andean-type subduction-related event; locally referred to in India as the Ladakh Batholith [e.g., Frank et al., 1977; Honegger et al., 1982; Weinberg and Dunlap, 2000] and in Pakistan as the Kohistan Batholith [e.g., Krol et al., 1996; Petterson and Windley, 1985, 1991]. The presence of Precambrian zircons in the detritus suggests additional sediment sourcing from Eurasian continental crust, i.e., the Karakoram/Lhasa Block [Wu et al., 2007]. The southern margin of the Dras arc experienced shallow marine deposition of the Khalsi Limestone, with the forearc basin south of the Dras arc dominated by deposition of volcaniclastic marine sediments of the Nindam Formation.

[73] 2. Continental sedimentation in an internally drained basin occurs (Figure 15b; Chogdo Formation, 54.9-51 to 50.8-49.4 Ma). The cessation of marine conditions within the arc-bounded depression is well preserved within the sedimentary record with the termination of the Sumda Formation and subsequent conformable transitional marinecontinental sedimentation of the Chogdo Formation during post early Eocene times. Deltas were fed into the arcbounded basin from the north (and south), deriving sediments from the Dras/Kohistan-Ladakh arc and Lhasa Block/ Karakoram, thus creating the Chogdo Formation. Ultramafic rocks were either sourced directly from the Dras Arc and/or Kohistan-Ladakh arc oceanic crust basement, or potentially from the SSZ.

[74] 3. Marine incursion occurs (Figure 15c; Nummulitic Limestone, $50.8<49.4 \mathrm{Ma}$ ). Sedimentation in the continental arc-bounded basin retrograded and there was a return to shallow marine conditions on the southern margin of the continental arc; marked by the conformable transition into the Nummulitic Limestone. The notable change in detrital zircon Jurassic $\mathrm{U}-\mathrm{Pb}$ ages (either sourced from the Dras Arc complex, Karakoram or Lhasa Block) in the Nummulitic Limestone, suggests that fluvial sediment was sourced from new arc areas.

[75] 4. Northern-derived transverse alluvial drainage following the final retreat of the Tethys ocean occurs (Figure 15d; Nurla and Choksti Formations, <50.8-49.4 to c. $24 \mathrm{Ma}$ ). The collision of India with the southern margin of Eurasia caused an end to marine deposition and return to continental sedimentation, and it is favored that this represents a constraint to the timing of India-Eurasia collision by 50.8 to $49.4 \mathrm{Ma}$ as defined by the youngest marine facies of the Nummulitic Limestone. The conformable transitional switch to continental sedimentation is marked by the Nurla Formation in a deltaic environment similar to that of the Chogdo Formation. As collision progressed, erosion from the relatively higher-relief Eurasian margin resulted in the development of large northerly derived, southerly directed

Figure 15. Paleoenvironmental reconstruction model focusing on deposition of the Indus Basin sedimentary rocks throughout the early phases of India-Eurasia collision. Model is not to scale, and regional geology and tectonics have been simplified. See section 10 for full explanation. KLIA, Kohistan-Ladakh Island Arc; SSZ, Shyok Suture Zone; TSS, Tethyan Sedimentary Series; STDZ, South Tibetan Detachment Zone; MCT, Main Central Thrust. 
alluvial fan and/or braided river deposits of the Choksti Formation's Basal Conglomerate and Red Shale Member. However, due to faulting within the stratigraphy we acknowledge that a significant part of the sedimentary record is unaccountable between the Nurla, Choksti Formation's Basal Conglomerate, and Red Shale Member.

[76] 5. Paleo-Indus axial river initiation occurs (Figure 15e; Nimu Formation and possibly Upper Choksti Formation, c. $24 \mathrm{Ma})$. We suggest that a well-established axial Indus River, flowing west along the suture zone, did not initiate in this region until Nimu Formation times (or potentially as early as Upper Choksti Formation depositional times), as recorded by northwest directed paleocurrents and the development of a large single channel river system fed by sediment from both the Eurasian and Indian margins. Initial paleoIndus River development was likely to have evolved from braided alluvial and intermontane basin lake sedimentation as recorded in the Middle-Upper Choksti Formation Sand- stone Members. Exhumation of the metamorphosed Higher Himalayan Crystalline terrane occurred through the development of the MCT and Zanskar Thrust systems that took place by c. $24 \mathrm{Ma}$, which increased the relative relief of the Indian margin, feeding early exhumed High Himalayanderived micas into the suture zone. The presence of these detrital micas, with ages as young as $23 \mathrm{Ma}$, within the Indus Group implies that suture zone sedimentation continued until at least the Late Miocene.

[77] Acknowledgments. This work was funded by NERC grant NE/ D000092/1 to Y.N. and NERC Ph.D. studentship NER/S/A/2006/14020 to A.L.H. Thanks are due to NIGL, Keyworth, for help with sample preparation, Fida Hussein for help with field logistics, and Kieran Craven and Tom Webster for field assistance. We would also like to thank Cairn India for their assistance with the shipment of rock samples. This paper benefited from careful reviews by Dave Rowley and an anonymous reviewer.

\section{References}

Aitchison, J. C., et al. (2002), New constraints on the India-Asia collision: The Lower Miocene Gangrinboche conglomerates, Yarlung Tsangpo suture zone, SE Tibet, J. Asian Earth Sci., 21(3), 251-263, doi:10.1016/S1367-9120(02)00037-8.

Allégre, C. J., et al. (1984), Structure and evolution of the Himalaya-Tibet Orogenic belt, Nature, 307(5946), 17-22, doi:10.1038/307017a0.

Andrews-Speed, C. P., and M. E. Brookfield (1982), Middle Paleozoic to Cenozoic geology and tectonic evolution of the northwestern Himalaya, Tectonophysics, 82(3-4), 253-275, doi:10.1016/0040-1951 (82)90048-8.

Baud, A., et al. (1982), Le contact Gondwana-peri Gondwana dans le Zanskar oriental (Ladakh, Himalaya), Bull. Soc. Geol. Fr., 24(2), 341-361.

Berggren, W. A., et al. (1995), Late Neogene chronology: New perspectives in high-resolution stratigraphy, Geol. Soc. Am. Bull., 107(11), 1272-1287, doi:10.1130/0016-7606(1995)107<1272:LNCNPI> 2.3.CO;2.

BouDagher-Fadel, M. (2008), Evolution and Geological Significance of Larger Benthic Foraminifera, 544 pp., Elsevier Sci., Amsterdam.

Brewer, I., et al. (2006), Downstream development of a detrital cooling-age signal: Insights from ${ }^{40} \mathrm{Ar} /{ }^{39} \mathrm{Ae}$ muscovite thermochronology in the Nepalese Himalaya, in Tectonics, Climate and Landscape Evolution, edited by S. D. Willett et al., Spec. Pap. 398, pp. 321-338, Geol. Soc. of Am., Boulder, Colo., doi:10.1130/2006.2398(20).

Brookfield, M. E., and C. P. Andrews-Speed (1984), Sedimentology, petrography and tectonic significance of the shelf, flysch and molasse clastic deposits across the Indus Suture Zone, Ladakh, NW India, Sediment. Geol., 40(4), 249-286, doi:10.1016/0037-0738(84)90011-3.

Chu, M.-F., et al. (2006), Zircon U-Pb and Hf isotope constraints on the Mesozoic tectonics and crustal evolution of southern Tibet, Geology, 34, 745-748, doi:10.1130/G22725.1.

Clift, P. D., et al. (2000), Sedimentary and geochemical evolution of the Dras forearc basin, Indus suture, Ladakh Himalaya, India, Geol. Soc. Am. Bull., 112(3), 450-466, doi:10.1130/0016-7606(2000) 112<450:SAGEOT $>2.0 . \mathrm{CO} ; 2$

Clift, P. D., et al. (2001a), Tracing patterns of erosion and drainage in the Paleogene Himalaya through ion probe $\mathrm{Pb}$ isotope analysis of detrital $\mathrm{K}$ feldspars in the Indus molasse, India, Earth Planet. Sci. Lett., 188(3-4), 475-491, doi:10.1016/S0012821X(01)00346-6.

Clift, P. D., et al. (2001b), Development of the Indus Fan and its significance for the erosional history of the western Himalaya and Karakoram, Geol. Soc. Am. Bull., 113(8), 1039-1051, doi:10.1130/ 0016-7606(2001)113<1039:DOTIFA>2.0.CO;2.

Clift, P. D., A. Carter, M. Krol, and E. Kirby (2002a), Constraints on India-Eurasia collision in the Arabian Sea region taken from the Indus Group, Ladakh Himalaya, India, in The Tectonic and Climatic Evolution of the Arabian Sea Region, Spec. Pap. 195, pp. 97-116, Geol. Soc. of London, Bath, U. K.

Clift, P. D., et al. (2002b), $\mathrm{Nd}$ and $\mathrm{Pb}$ isotope variability in the Indus River system: Implications for sediment provenance and crustal heterogeneity in the western Himalaya, Earth Planet. Sci. Lett., 200(1-2), 91-106, doi:10.1016/S0012-821X(02)00620-9.

Corfield, R. I., and M. P. Searle (2000), Crustal shortening estimates across the north Indian continental margin, Ladakh, NW India, in Tectonics of the Nanga Parbat Syntaxis and the Western Himalaya, edited by M. A. Khan et al., Spec. Publ. 170, pp. 385-410, Geol. Soc. of London, Bath, U. K.

Corfield, R. I., et al. (2001), Tectonic setting, origin, and obduction history of the Spontang ophiolite, Ladakh Himalaya, NW India, J. Geol., 109(6), 715-736, doi:10.1086/323191.

Coward, M. P., B. F. Windley, R. D. Broughton, I. W. Luff, M. G. Petterson, C. J. Pudsey, D. C. Rex, and M. Asif Khan (1986), Collision tectonics in the NW Himalayas, in Collision Tectonics, Geol. Soc. Spec. Publ., edited by M. P. Coward and A. C. Ries, pp. 203-219, Blackwell Sci., Oxford, U. K.

DeCelles, P. G., et al. (2000), Tectonic implications of $\mathrm{U}-\mathrm{Pb}$ zircon ages of the Himalayan orogenic belt in Nepal, Science, 288(5465), 497-499, doi:10.1126/ science. 288.5465 .497

de Sigoyer, J., et al. (2000), Dating the Indian continental subduction and collisional thickening in the northwest Himalaya: Multichronology of the Tso Morari eclogites, Geology, 28, 487-490, doi:10.1130/0091-7613(2000)28<487:DTICSA> 2.0.CO;2.

Dèzes, P. J. (1999), Tectonic and Metamorphic Evolution of the Central Himalayan Domain in Southeast Zanskar (Kashmir, India), Mem. Geol., vol. 32, 149 pp., Univ. de Lausanne, Lausanne, Switzerland.

Dickinson, W. R. (1985), Interpreting provenance relations from detrital modes of sandstones, in Provenance of Arenites, edited by G. G. Zuffa, pp. 333-361, D. Reidel, Dordrecht.

Dickinson, W. R., and C. A. Suczek (1979), Plate tectonics and sandstone compositions, AAPG Bull., 63(12), 2164-2182.

Foster, G., and A. Carter (2007), Insights into the patterns and locations of erosion in the Himalaya: A combined fission track and in situ $\mathrm{Sm}-\mathrm{Nd}$ iso- topic study of detrital apatite, Earth Planet. Sci. Lett., 257(3-4), 407-418, doi:10.1016/j.epsl.2007.02.044.

Frank, W., A. Gansser, and V. Trommsdorf (1977), Geological observations in the Ladakh area (Himalaya): A preliminary report, Schweiz. Mineral. Petrogr. Mitt., 57, 89-113.

Frank, W., C. Miller, and B. Grasemann (1995), Ar/ Ar-ages of detrital micas and palaeogeographic provenance of Proterozoic clastic sediments in the Himalayas, in 10th Himalaya-Karakoram-Tibet Workshop, Centro Stefano Franscini (the ETH Conference Center), Monte Verita, Ascona, Switzerland, 4-8 April, 1995, edited by D. A. Spencer et al., Zürich, Switzerland.

Fuchs, G. (1979), On the geology of western Ladakh, Jahrb. Geol. Bundesanst., 122(2), 513-540.

Fuchs, G. (1981), Outline of the geology of the Himalaya, Mitt. Oesterr. Geol. Ges., 74, 101-127.

Gaetani, M. (1997), The Karakorum Block in central Asia, from Ordovician to Cretaceous, Sediment. Geol., 109(3-4), 339-359, doi:10.1016/S00370738(96)00068-1.

Gaetani, M., and E. Garzanti (1991), Multicyclic history of the northern India continental-margin (northwestern Himalaya), AAPG Bull., 75(9), 1427-1446.

Gaetani, M., et al. (1993), Jurassic and Cretaceous orogenic events in the north Karakoram: Age constraints from sedimentary rocks, Geol. Soc. Spec. Publ., 74(1), 39-52.

Gansser, A. (1977), The great suture zone between Himalaya and Tibet, a preliminary account, in Himalaya, Sciences de la Terre, Colloq. Int. du CNRS, vol. 268, pp. 181-191, Cent. Natl. Rech. Sci., Paris.

Garzanti, E., and T. van Haver (1988), The Indus clastics: Fore-arc basin sedimentation in the Ladakh Himalaya (India), Sediment. Geol., 59(3-4), 237-249, doi:10.1016/0037-0738(88)90078-4.

Garzanti, E., et al. (1987), Sedimentary record of the northward flight of India and its collision with Eurasia (Ladakh Himalaya, India), Geodin. Acta, 1(4-5), 297-312.

Garzanti, E., et al. (2007), Orogenic belts and orogenic sediment provenance, J. Geol., 115(3), 315-334, doi: $10.1086 / 512755$.

Gehrels, G. E., et al. (2003), Initiation of the Himalayan orogen as an Early Paleozoic thin-skinned thrust belt, GSA Today, 13(9), 4-9, doi:10.1130/10525173(2003)13<4:IOTHOA $>2.0 . \mathrm{CO} ; 2$

Gradstein, F. M., et al. (2004), A Geologic Time Scale, 588 pp., Cambridge Univ. Press, Cambridge, U. K.

Green, O. R., et al. (2008), Cretaceous-Tertiary carbonate platform evolution and the age of the India-Asia collision along the Ladakh Himalaya (northwest 
India), J. Geol., 116(4), 331-353, doi:10.1086/ 588831 .

Harrison, T. M., et al. (2000), The Zedong window: A record of superposed Tertiary convergence in southeastern Tibet, J. Geophys. Res., 105, 19,211-19,230, doi:10.1029/2000JB900078.

Henderson, A. L., et al. (2010), Testing the application of in situ Sm-Nd isotopic analysis on detrital apatites: A provenance tool for constraining the timing of India-Eurasia collision, Earth Planet. Sci. Lett., 297(1-2), 42-49.

Heuberger, S., et al. (2007), Age and isotopic constraints on magmatism along the KarakoramKohistan Suture Zone, NW Pakistan: Evidence for subduction and continued convergence after IndiaAsia collision, Swiss J. Geosci., 100(1), 85-107, doi:10.1007/s00015-007-1203-7.

Hodges, K. V., et al. (1996), Tectonic evolution of the Central Annapurna Range, Nepalese Himalayas, Tectonics, 15, 1264-1291, doi:10.1029/96TC01791.

Honegger, K., et al. (1982), Magmatism and metamorphism in the Ladakh Himalayas (the IndusTsangpo Suture Zone), Earth Planet. Sci. Lett., 60(2), 253-292, doi:10.1016/0012-821X(82)90007-3.

Honegger, K., et al. (1989), The blueschists along the Indus Suture Zone in Ladakh, NW Himalaya, J. Metamorph. Geol., 7(1), 57-72, doi:10.1111/ j.1525-1314.1989.tb00575.x.

Horstwood, M. S. A., et al. (2003), Common-Pb corrected in situ U-Pb accessory mineral geochronology by LA-MC-ICP-MS, J. Anal. At. Spectrom., 18(8), 837-846, doi:10.1039/b304365g.

Ingersoll, R. V., et al. (1984), The effect of grain-size on detrital modes: A test of the Gazzi-Dickinson point-counting method, J. Sediment. Petrol., 54, $103-116$.

Jäger, E. (1967), Die Bedeutung der Biotit-alterswerte, in $\mathrm{Rb}-\mathrm{Sr}$ Altersbestimmungen an Glimmern der Zentralalpen, Beitr. Geol. Karte Schweiz, edited by E. N. Jäger and E. Wenk, pp. 28-31, Kümmerly and Frey, Bern.

Jorgensen, D. W., et al. (1993), Hydrology and geomorphology of the Indus River in Sindh: Implications for the Mohen jo Daro site, in Himalayas to the Sea: Geology, Geomorphology and the Quaternary, edited by J. Shroder and A. Kazmi, Routledge, London, doi:10.4324/9780203414637 chapter 15.

Khan, S. D., et al. (2009), Did the Kohistan-Ladakh island arc collide first with India?, Geol. Soc. Am. Bull., 121(3-4), 366-384, doi:10.1130/B26348.1.

Krol, M. A., et al. (1996), Episodic unroofing of the Kohistan Batholith, Pakistan: Implications from K-feldspar thermochronology, J. Geophys. Res., 101, 28,149-28,164, doi:10.1029/96JB01503.

Leech, M. L., et al. (2005), The onset of India-Asia continental collision: Early, steep subduction required by the timing of UHP metamorphism in the western Himalaya, Earth Planet. Sci. Lett., 234(1-2), 83-97, doi:10.1016/j.eps1.2005.02.038.

Le Fort, P. (1996), Evolution of the Himalaya, in The Tectonic Evolution of Asia, edited by A. Yin and T. M. Harrison, pp. 95-109, Cambridge Univ. Press, Cambridge, U. K.

Le Fort, P., et al. (1994), Discovery of a crystalline basement and Early Ordovician marine transgression in the Karakorum mountain range, Pakistan, Geology, 22, 941-944, doi:10.1130/0091-7613 (1994) $022<0941$ :DOACBA $>2.3 . C O ; 2$.

Leier, A. L., et al. (2007), The Takena Formation of the Lhasa terrane, southern Tibet: The record of a Late Cretaceous retroarc foreland basin, Geol. Soc. Am. Bull, 119(1-2), 31-48, doi:10.1130/B25974.1.

Mahéo, G., et al. (2004), The south Ladakh ophiolites (NW Himalaya, India): An intra-oceanic tholeiitic arc origin with implication for the closure of the Neo-Tethys, Chem. Geol., 203(3-4), 273-303, doi:10.1016/j.chemgeo.2003.10.007.

Maheo, G., et al. (2006), Relicts of an intra-oceanic arc in the Sapi-Shergol melange zone (Ladakh, NW Himalaya, India): Implications for the closure of the Neo-Tethys Ocean, J. Asian Earth Sci., 26(6), 695-707, doi:10.1016/j.jseaes.2005.01.004.
Mark, D. F., et al. (2009), The ARGUS multicollector noble gas mass spectrometer: Performance for ${ }^{40} \mathrm{Ar} /{ }^{39} \mathrm{Ar}$ geochronology, Geochem. Geophys. Geosyst., 10, Q0AA02, doi:10.1029/2009GC002643.

McDougall, I., and T. M. Harrison (1999), Geochronology and Thermochronology by the ${ }^{40}$ Ar/ ${ }^{39}$ Ar Method, 288 pp., Oxford Univ. Press, Oxford, U. K

Miller, C., et al. (2000), Proterozoic crustal evolution in the NW Himalaya (India) as recorded by circa $1.80 \mathrm{Ga}$ mafic and $1.84 \mathrm{Ga}$ granitic magmatism, Precambrian Res., 103, 191-206, doi:10.1016/ S0301-9268(00)00091-7.

Murphy, M. A., et al. (1997), Significant crustal shortening in south-central Tibet prior to the Indo-Asia collision, Geology, 25, 719-722, doi:10.1130/ 0091-7613(1997)025<0719:DTIACA > 2.3.CO;2.

Myrow, P. M., et al. (2003), Integrated tectonostratigraphic analysis of the Himalaya and implications tor its tectonic reconstruction, Earth Planet. Sci. Lett., 212(3-4), 433-441, doi:10.1016/S0012 $821 \mathrm{X}(03) 00280-2$

Najman, Y. (2006), The detrital record of orogenesis: A review of approaches and techniques used in the Himalayan sedimentary basins, Earth Sci. Rev., 74 , $1-72$.

Najman, Y., and E. Garzanti (2000), Reconstructing early Himalayan tectonic evolution and paleogeography from Tertiary foreland basin sedimentary rocks, northern India, Geol. Soc. Am. Bull., 112(3), 435-449, doi:10.1130/0016-7606(2000)112<435: REHTEA $>2.0 . \mathrm{CO} ; 2$.

Najman, Y., et al. (2008), The Paleogene record of Himalayan erosion: Bengal Basin, Bangladesh, Earth Planet. Sci. Lett., 273(1-2), 1-14, doi:10.1016/j. eps1.2008.04.028.

Oliver, G. J. H., et al. (1995), Age of metamorphism in the Lesser Himalaya and the main central thrus zone, Garhwal India: Results of illite crystallinity, ${ }^{40} \mathrm{Ar}-{ }^{39} \mathrm{Ar}$ fusion and K-Ar studies, Geol. Mag., 132, 139-149, doi:10.1017/S0016756800011717.

Parrish, R. R., and K. V. Hodges (1996), Isotopic constraints on the age and provenance of the Lesser and Greater Himalayan sequences, Nepalese Himalaya, Geol. Soc. Am. Bull., 108(7), 904-911, doi:10.1130/ 0016-7606(1996)108<0904:ICOTAA > 2.3.CO;2

Petterson, M. G., and B. F. Windley (1985), Rb-Sr dating of the Kohistan arc-batholith in the transHimalaya of north Pakistan, and tectonic implications, Earth Planet. Sci. Lett., 74(1), 45-57, doi:10.1016/0012-821X(85)90165-7.

Petterson, M. G., and B. F. Windley (1991), Changing source regions of magmas and crustal growth in the trans-Himalayas: Evidence from the Chalt volcanics and Kohistan batholith, Kohistan, northern Pakistan, Earth Planet. Sci. Lett., 102(3-4), 326-341, doi:10.1016/0012-821X(91)90027-F.

Pointet, A. (2004), Indus-Zanskar-Pangong, in Ladakh and Zanskar Centre, Ed. Olizane, Geneva, Switzerland.

Powell, C. M., and P. J. Conaghan (1973), Plate tectonics and the Himalayas, Earth Planet. Sci. Lett., 20(1), 1-12, doi:10.1016/0012-821X(73)90134-9.

Prince, C. I., G. Foster, D. Vance, N. Harris, and J. Baker (1999), The thermochronology of the high Himalayan crystallines in the Garhwal Himalaya: Prograde history of a polymetamorphic slab, Terra Nostra, 99(2), 119-120.

Ramsey, M. H., et al. (1995), An objective assessment of analytical method precision: Comparison of ICP-AES and XRF for the analysis of silicate rocks, Chem. Geol., 124(1-2), 1-19, doi:10.1016/00092541(95)00020-M.

Renne, P. R., et al. (1998), Intercalibration of standards, absolute ages and uncertainties in ${ }^{40} \mathrm{Ar} /{ }^{39} \mathrm{Ar}$ dating, Chem. Geol., 145(1-2), 117-152, doi:10.1016 S0009-2541(97)00159-9.

Reuber, I. (1989), The Dras arc: Two successive volcanic events on eroded oceanic crust, Tectonophysics, 161(1-2), 93-106, doi:10.1016/0040-1951(89) 90305-3.

Reuber, I., et al. (1989), K-Ar ages of ophiolites and arc volcanics of the Indus Suture Zone: Clues on early evolution of the Neo-Tethys, Eclogae Geol. Helv., $82,699-715$.

Richards, A., et al. (2005), Himalayan architecture constrained by isotopic tracers from clastic sediments, Earth Planet. Sci. Lett., 236, 773-796, doi:10.1016/ j.epsl.2005.05.034.

Robertson, A. H. F. (2000), Formation of melanges in the Indus Suture Zone, Ladakh Himalaya by successive subduction-related, collisional and postcollisional processes during Late Mesozoic-Late Tertiary time, Geol. Soc. Spec. Publ., 170(1), 333-374.

Robertson, A. H. F., and A. S. Collins (2002), Shyok Suture Zone, N Pakistan: Late Mesozoic-Tertiary evolution of a critical suture separating the oceanic Ladakh Arc from the Asian continental margin, J. Asian Earth Sci., 20(3), 309-351, doi:10.1016/ S1367-9120(01)00041-4.

Robertson, A., and P. Degnan (1994), The Dras arc complex: Lithofacies and reconstruction of a Late Cretaceous oceanic volcanic arc in the Indus Suture Zone, Ladakh-Himalaya, Sediment. Geol., 92(1-2), 117-145, doi:10.1016/0037-0738(94)90057-4.

Rolland, Y., et al. (2000), Middle Cretaceous back-arc formation and arc evolution along the Asian margin: The Shyok Suture Zone in northern Ladakh (NW Himalaya), Tectonophysics, 325(1-2), 145-173, doi:10.1016/S0040-1951(00)00135-9.

Rolland, Y., et al. (2002a), Presence and geodynamic significance of Cambro-Ordovician series of SE Karakoram (N Pakistan), Geodin. Acta, 15, 1-21, doi:10.1016/S0985-3111(01)01075-0.

Rolland, Y., et al. (2002b), The cretaceous Ladakh arc of NW Himalaya: Slab melting and melt-mantle interaction during fast northward drift of Indian Plate, Chem. Geol., 182(2-4), 139-178, doi:10.1016/ S0009-2541(01)00286-8.

Schaltegger, U., et al. (2002), Multiple mantle sources during island arc magmatism: $\mathrm{U}-\mathrm{Pb}$ and $\mathrm{Hf}$ isotopic evidence from the Kohistan arc complex, Pakistan, Terra Nova, 14, 461-468, doi:10.1046/j.13653121.2002.00432.x

Schärer, U, et al. (1984a), The Transhimalaya (Gangdese) plutonism in the Ladakh region: $\mathrm{A} \mathrm{U}-\mathrm{Pb}$ and Rb-Sr study, Earth Planet. Sci. Lett., 67(3), 327-339, doi:10.1016/0012-821X(84)90172-9.

Schärer, U., et al. (1984b), U-Pb geochronology of Gangdese (Transhimalaya) plutonism in the LhasaXigaze region, Tibet, Earth Planet. Sci. Lett., 69(2), 311-320, doi:10.1016/0012-821X(84)90190-0.

Schlup, M., et al. (2003), Exhumation history of eastern Ladakh revealed by ${ }^{40} \mathrm{Ar} /{ }^{39} \mathrm{Ar}$ and fission-track ages: The Indus River-Tso Morari transect, NW Himalaya, J. Geol. Soc. London, 160, 385-399, doi:10.1144/0016-764902-084

Searle, M. P., et al. (1988), Collision tectonics of the Ladakh-Zanskar Himalaya, in Tectonic Evolution of the Himalayas and Tibet, edited by R. M. Shackleton, J. F. Dewey, and B. F. Windley, pp. 117-150, R. Soc., London.

Searle, M. P., et al. (1990), Restoration and evolution of the intermontane Indus molasse basin, Ladakh Himalaya, India, Tectonophysics, 174(3-4), 301-314, doi:10.1016/0040-1951(90)90327-5.

Searle, M. P., et al. (1992), Pressure, temperature and time constraints on Himalayan metamorphism from eastern Kashmir and western Zanskar, J. Geol. Soc. London, 149, 753-773, doi:10.1144/gsjgs.149.5.0753.

Searle, M., et al. (1997a), Structure of the north Indian continental margin in the Ladakh-Zanskar Himalayas: Implications for the timing of obduction of the Spontang ophiolite, India-Asia collision and deformation events in the Himalaya, Geol. Mag., 134, 297-316, doi:10.1017/S0016756897006857.

Searle, M. P., et al. (1997b), Shisha Pangma leucogranite, south Tibetan Himalaya: Field relations, geochemistry, age, origin, and emplacement, J. Geol., 105(3), 295-318, doi:10.1086/515924

Searle, M. P., et al. (1999), The tectonic evolution of the Kohistan-Karakoram collision belt along the Karakoram Highway transect, north Pakistan, Tectonics, 18, 929-949, doi:10.1029/1999TC900042. 
Shah, S. K., et al. (1976), Stratigraphy and structure of the western part of the Indus suture belt, Ladakh, northwestern Himalaya, Himalayan Geol., 6, 534-556.

Sharma, K. K., and K. R. Gupta (1983), Calc-alkaline island arc volcanism in the Indus-Tsangpo suture zone, in Geology of Indus Suture Zone of Ladakh, edited by K. K. Sharma et al., pp. 71-78, Wadia Inst. Himalayan Geol., Dehra Dun, India.

Simpson, R. L., et al. (2000), Two episodes of monazite crystallization during metamorphism and crustal melting in the Everest region of the Nepalese Himalaya, Geology, 28, 403-406, doi:10.1130/ 0091-7613(2000)28<403:TEOMCD $>2.0 . \mathrm{CO} ; 2$.

Sinclair, H. D., and N. Jaffey (2001), Sedimentology of the Indus group, Ladakh, northern India: Implications for the timing of initiation of the palaeo-Indus River, J. Geol. Soc. London, 158, 151-162, doi:10.1144/jgs.158.1.151.

Steck, A. (2003), Geology of the NW Indian Himalaya, Eclogae Geol. Helv., 96, 147-196.

Steck, A. S., et al. (1993), The tectonic evolution of the north western Himalaya in eastern Ladakh and Lahul, India, in Himalayan Tectonics, Geol. Soc. Spec. Publ., vol. 74, edited by P. J. Treloar and M. P. Searle, pp. 265-276, Geol. Soc., London.

Sutre, E. (1990), Les formations de la marge nordNeotethsieene et les melanges ophiolitic de la zone de suture de l'Indus en Himalaya du Ladakh, Ph.D. thesis, 295 pp., L'Universite de Poiters, Poiters, France.

Szulc, A. G., et al. (2006), Tectonic evolution of the Himalaya constrained by detrital Ar-40-Ar-39, Sm-Nd and petrographic data from the Siwalik foreland basin succession, SW Nepal, Basin Res., 18(4), 375-391, doi:10.1111/j.1365-2117.2006.00307.x.

Taylor, S. R., and S. M. McLennan (1985), The Continental Crust: Its Composition and Evolution: An Examination of the Geochemical Record Preserved in Sedimentary Rocks, Blackwell Sci., Oxford, U. K.

Tewari, A. P. (1964), On the upper tertiary deposits of Ladakh Himalayas and correlation of various geotectonic units of Ladakh with those of the Kumaon-Tibet region, Proc. Int. Geol. Congr., 11, $37-58$.

Tewari, V. C. (1993), Precambrian and Lower Cambrian stromatolites of the Lesser Himalaya, Geophytology, 23, 19-39.

Thakur, V. C. (1981), Regional framework and geodynamic evolution of the Indus-Tsangpo Suture Zone, Ladakh Himalaya, Trans. R. Soc. Edinburgh Earth Sci., 72, 89-97.

Thakur, V. C., and D. K. Mishra (1984), Tectonic framework of the Indus and Shyok suture zones in eastern Ladakh, northwest Himalaya, Tectonophy- sics, 101(3-4), 207-220, doi:10.1016/0040-1951 (84)90114-8

Tonarini, S., et al. (1993), Eocene age of eclogite metamorphism in Pakistan Himalaya: Implications for India Eurasia collision, Terra Nova, 5, 13-20, doi:10.1111/j.1365-3121.1993.tb00221.x.

Treloar, P. J. (1997), Thermal controls on early Tertiary, short-lived, rapid regional metamorphism in the NW Himalaya, Pakistan, Tectonophysics, 273(1-2), 77-104, doi:10.1016/S0040-1951(96)00289-2.

Treloar, P. J., et al. (1989a), K-Ar and Ar-Ar geochronology of the Himalayan collision in NW Pakistan: Constraints on the timing of suturing, deformation, metamorphism and uplift, Tectonics, 8, 881-909, doi:10.1029/TC008i004p00881.

Treloar, P. J., et al. (1989b), Metamorphism and crustal stacking in the North Indian Plate, north Pakistan, Tectonophysics, 165(1-4), 167-184, doi:10.1016/ 0040-1951(89)90045-0.

Treloar, P. J., et al. (1996), A re-evaluation of the stratigraphy and evolution of the Kohistan arc sequence, Pakistan Himalaya: Implications for magmatic and tectonic arc-building processes, J. Geol. Soc. London, 153, 681-693, doi:10.1144/gsjgs.153.5.0681.

Treloar, P. J., et al. (2003), Exhumation of early Tertiary, coesite-bearing eclogites from the Pakistan Himalaya, J. Geol. Soc. London, 160, 367-376, doi:10.1144/0016-764902-075.

Valdiya, K. S. (1980), Geology of Kumaun Lesser Himalaya, 291 pp., Wadia Inst. Himalayan Geol., Dehra Dun, India.

Valdiya, K. S., and S. B. Bhatia (Eds.) (1980), Stratigraphy and Correlations of Lesser Himalayan Formations, 330 pp., Hindustan, Delhi.

Vance, D., and N. Harris (1999), Timing of prograde metamorphism in the Zanskar Himalaya, Geology, 27, 395-398, doi:10.1130/0091-7613(1999)027 $<0395$ :TOPMIT $>2.3$.CO; 2 .

van Haver, T. (1984), Etude Stratigraphique, Sedimentologique et Structurale d'un Bassin d'Avant Arc: Exemple du Bassin de l'Indus, Ladakh. Himalaya, 204 pp., Univ. de Grenoble, Grenoble, France.

Vannay, J. C., and K. V. Hodges (1996), Tectonometamorphic evolution of the Himalayan metamorphic core between Annapurna and Dhaulagiri, central Nepal, J. Metamorph. Geol., 14(5), 635-656, doi:10.1046/j.1525-1314.1996.00426.x.

von Blanckenburg, F., I. M. Villa, H. Baur, G. Morteani, and R. H. Steiger (1989), Time calibration of a PTpath from the Western Tauern Window, Eastern Alps: The problem of closure temperatures, Contrib. Mineral. Petrol., 101(1), 1-11, doi:10.1007/ BF00387196.
Walker, J. D., et al. (1999), Metamorphism, melting, and extension: Age constraints from the High Himalayan Slab of southeast Zanskar and northwes Lahaul, J. Geol., 107(4), 473-495, doi:10.1086 314360 .

Watson, J. S. (1996), Fast, simple method of powder pellet preparation for X-ray fluorescence analysis, X Ray Spectrom., 25(4), 173-174, doi:10.1002/ (SICI) 1097-4539(199607)25:4<173::AIDXRS158>3.0.CO $2-\mathrm{Z}$

Weinberg, R. F., and W. J. Dunlap (2000), Growth and deformation of the Ladakh batholith, northwest Himalayas: Implications for timing of continental collision and origin of calc-alkaline batholiths, J. Geol., 108(3), 303-320, doi:10.1086/314405.

Wen, D.-R., et al. (2008), Zircon SHRIMP U-Pb ages of the Gangdese Batholith and implications for Neotethyan subduction in southern Tibet, Chem. Geol., 252(3-4), 191-201, doi:10.1016/j. chemgeo.2008.03.003

White, N. M., et al. (2002), Constraints on the exhumation and erosion of the High Himalayan Slab, NW India, from foreland basin deposits, Earth Planet Sci. Lett., 195(1-2), 29-44, doi:10.1016/S0012$821 \mathrm{X}(01) 00565-9$.

Wu, F. Y., et al. (2007), Zircon Hf isotopic constraints on the sources of the Indus molasse, Ladakh Himalaya, India, Tectonics, 26, TC2014, doi:10.1029/ 2006TC002051.

$\mathrm{Xu}, \mathrm{R}$. H., et al. (1985), Magmatism and metamorphism in the Lhasa Block (Tibet): A geochronological study, J. Geol., 93(1), 41-57, doi:10.1086/628918.

Zeitler, P., et al. (2001), Crustal reworking at Nanga Parbat, Pakistan: Metamorphic consequences of thermal-mechanical coupling facilitated by erosion, Tectonics, 20, 712-728, doi:10.1029/2000TC001243.

S. Andò and E. Garzanti, Dipartimento di Scienze Geologiche e Geotecnologie, Universita MilanoBicocca, Piazza della Scienza 4, I-20126 Milan, Italy.

D. Barford, SUERC, Scottish Enterprise Technology

Park, Rankine Ave., Glasgow G75 OQF, UK.

M. BouDagher-Fadel, Department of Earth Sciences, University College London, Gower Street, London WC1E 6BT, UK.

A. L. Henderson and Y. Najman, Lancaster Environment Centre, University of Lancaster, Lancaster

LA1 3YQ, UK. (y.najman@lancaster.ac.uk)

R. Parrish, NERC Isotope Geosciences Laboratory, Kingsley Dunham Centre, Keyworth NG12 5GG, UK. 